\title{
ACTIVE TRANSPORTATION DEMAND MODELING AND INFRASTRUCTURE PERFORMANCE ASSESSMENT
}

\author{
by \\ Sheikh Ariful Alam, \\ Bachelor of Urban and Regional Planning, \\ Bangladesh University of Engineering and Technology,2008 \\ Dhaka, Bangladesh, \\ Master of Science, \\ KTH Royal Institute of Technology, 2013 \\ Stockholm, Sweden,
}

\author{
A Major Research Project \\ presented to Ryerson University \\ in partial fulfillment of the \\ requirements for the degree of \\ Master of Engineering \\ in the Program of \\ Civil Engineering \\ Toronto, Ontario, Canada, 2017 \\ @ Sheikh Ariful Alam, 2017
}


I hereby declare that I am the sole author of this MRP. This is a true copy of the MRP, including any required final revisions.

I authorize Ryerson University to lend this MRP to other institutions or individuals for the purpose of scholarly research.

I further authorize Ryerson University to reproduce this MRP by photocopying or by other means, in total or in part, at the request of other institutions or individuals for the purpose of scholarly research.

I understand that my MRP may be made electronically available to the public. 


\author{
ABSTRACT \\ Active Transportation Demand Modeling and Infrastructure Performance Assessment \\ Master of Engineering, 2017 \\ Sheikh Ariful Alam \\ Yeates School of Graduate Studies, Civil Engineering \\ Ryerson University
}

Due to obvious benefits and growing demand of active transportation, engineers and planners are eager to expand active transportation infrastructure facilities. However, no robust methodology has been developed for active transportation infrastructures assessment addressing its potential demand. This project aims to develop an integrated methodology estimate potential demand and to assess the infrastructures needs and quality, based on quantitative methods. A case study was conducted to apply these methods at North York Centre, City of Toronto. The potential active transportation demand was measured using short trips recorded in the area-wide transportation demand database. Quality of service, and connectivity measures were estimated for evaluating the performance of active transportation infrastructure. Quality of service includes Ottawa Multimodal Level of Service Guidelines, Pedestrian and Bike Level of Service from Highway Capacity Manual. The results show that the study area is operating at poor level of service and highly potential for active modes. Therefore, a new street design has been proposed to reach the desired performance level. 


\section{ACKNOWLEDGMENTS}

I acknowledge with deep sense of gratitude for the guidance, invaluable advice provided by my supervisor Dr. Said Easa, Professor, Civil Engineering, Ryerson University. He has always inspired and encouraged me throughout the period while providing the funding to complete my Major Research Project (MRP) successfully. I would like to specially thank my project committee members Dr. Lamya Amleh and Dr. Songnian Li for evaluating my report. I also would like to thank Dr. Essam Dabbour, Associate Professor, Civil Engineering, Abu Dhabi University for thoroughly reviewing the report and his valuable comments. I am grateful for having regular guidance, direction and advice from Dewan Masud Karim,PEng., Senior Planner, Transportation Planning, City of Toronto. Without his proper guidance and data support, this project would have not been completed in time. I am thankful to Dr. Mohammad Hossain, for reading my thesis thoroughly and suggesting the writing improvement. I would also like to thank my wife, Sangida Akter for her endless support and encouragement during my master's study. 


\section{TABLE OF CONTENTS}

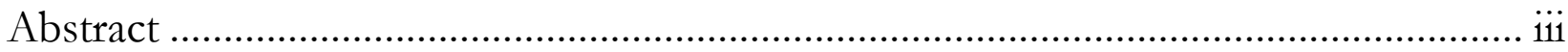

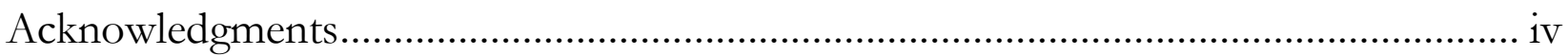

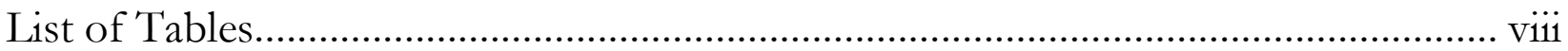

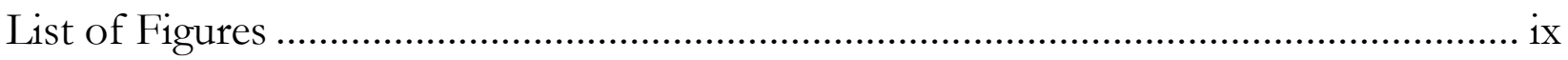

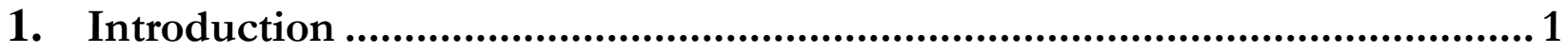

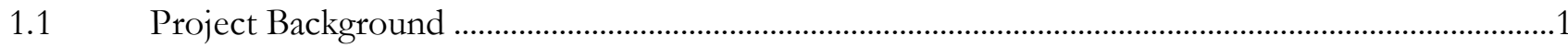

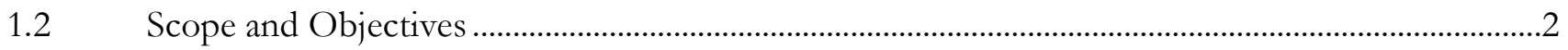

$1.3 \quad$ Report Organization .........................................................................................................

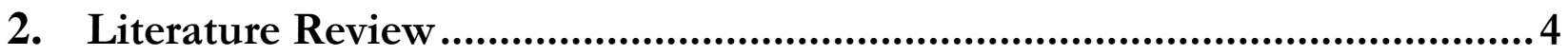

2.1 Benefits and Potential of Active TransportationMode Choice ……………………...........................4

2.2 Factors Affecting Active Transportation Demand and Modeling......................................................6

2.3 Active Transportation Performance Measure: Level of Service ..........................................................8

3. Modeling Framework ..................................................................................11

3.1 Proximity Analysis to Major Destinations ………………………………………………………... 11

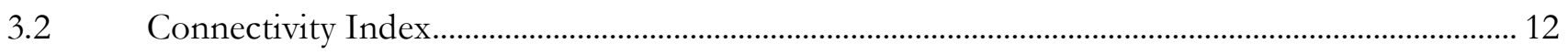

3.3 Multimodal Level of Service (LOS) Method …………………………………………………….... 15

3.3.1 Pedestrian Level of Service (PLOS) ………………………………………………………….... 16

3.3.2 Bicycle Level of Service (BLOS) .............................................................................................. 19

$3.4 \quad$ Pedestrian and Bicycle LOS Calculator ...............................................................................................2

4. Methodology and Data Collection ............................................................ 25 


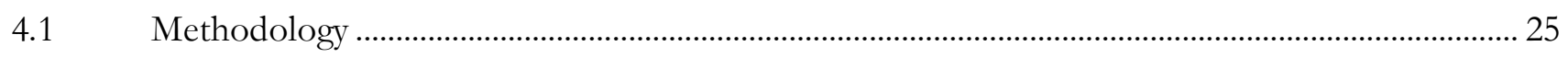

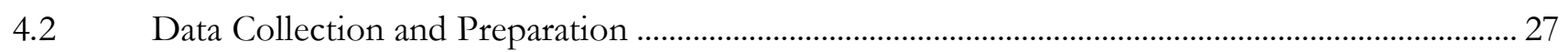

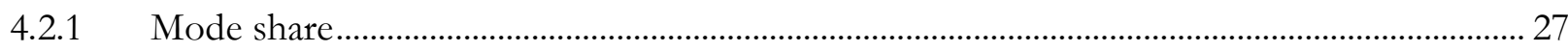

4.2.2 Traffic Movement Count (TMC) ………………………………………………………..... 27

4.2.3 Traffic Signal Operation ………………………………………………………………….... 27

4.2.4 Walking and Cycling Infrastructure............................................................................................. 28

4.2.5 Roadway Geometric design.......................................................................................... 28

4.2.6 Posted Speed ………………………………………………………………………………... 28

5. Case Study: Model Application \&Results .............................................29

5.1 Study Area in Multimodal Transportation Context........................................................................ 29

5.1.1 Transportation Network and Demand .................................................................................... 30

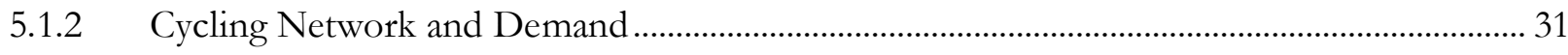

5.1.3 Walking Network and Demand .............................................................................................. 32

5.1.4 Study Area: walking and cycling problems and prospects ………………………………….... 33

5.2 Proximity to Rapid Transit Stations and Schools area........................................................................ 36

5.3 Connectivity Index: Active Mode...…………………………………………………………….... 37

5.4 Network Performance Analysis: Level of Service Methods ........................................................... 38

5.4.1 Pedestrian Network Level of Service ...................................................................................... 38

5.4.2 Cycling Network Level of Service ……………………………………………………….... 40

5.5 Estimating Active Transportation Demand ............................................................................... 41

5.5.1 Existing Active Transportation Travel Demand ...................................................................... 41

5.5.2 Estimation of Potential Trips .............................................................................................. 43

5.5.3 Potential Active Transportation Demand...…………………………………………………... 47

5.6 Evaluate Potential Demand Network Condition...................................................................................... 48

6. Evaluation of Infrastructure Improvements ........................................ 51 
6.1 Review the Roadway Design Guidelines ………...................................................................... 51

6.2 Redesign the Streets for potential multimodal transportaion users ............................................... 53

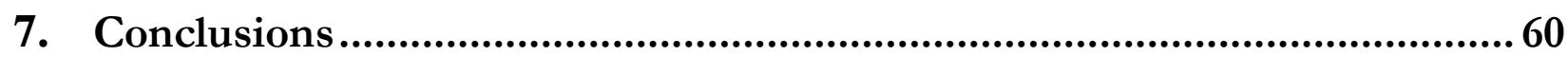

Appendix A: Traffic Volume Data .......................................................... 61

Appendix B: Model Criteria and Calculation Process ................................. 80

References ............................................................................................... 84 


\section{LIST OF TABLES}

Table 2-1: Factors those impacts on the Active Transportation Demand [ Source: (Litman, 2017) ] ..........7

Table 2-2: Pedestrian Level of Service Criteria for Sidewalks and Walkways [Source: (HCM, 2000)] .........8

Table 3-1: Types of Connectivity measures [Source: (Semler et al., 2016)] ……….......................................... 13

Table 3-2: Criteria that are considered for the PLOS tools. [source: (City of Ottawa, 2015)] .................... 17

Table 3-3: Pedestrian LOS Criteria and value. [source: (City of Ottawa, 2015)] .......................................... 18

Table 3-4: Criteria considered for the Bicycle LOS measure [Source: (City of Ottawa, 2015)]................... 20

Table 3-5: Bike LOS assessment chart [Source: (City of Ottawa, 2015)] ....................................................... 21

Table 3-6: Desired LOS for specific policy area context [ Source: (City of Ottawa, 2015) ] ....................... 22

Table 3-7: Bicycle and Pedestrian LOS parameters and description [Source: (League of Illinois Bicyclists,

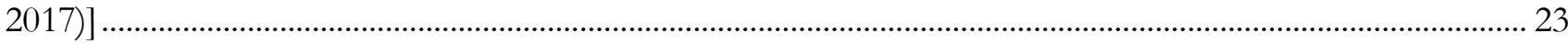

Table 3-8: The BLOS/PLOS calculator data input form ................................................................................... 24

Table 6-1: Street with Walking and Cycling Facility Design Standards ....................................................... 52

Table 6-2: Pedestrian and Bike Level of Service in different scenario ............................................................ 58 


\section{LIST OF FIGURES}

Figure 2-1: Pedestrian LOS [source: (HCM, 2000)] 9

Figure 3-1: Types of different Road network. [source: (The City of Calgary, 2010)] 13

Figure 3-2: Connectivity Index Sample Calculation. [source: (The City of Calgary, 2010)] 14

Figure 3-3: Active Transportation Connectivity Index threshold. 15

Figure 3-4: MMLOS ranges for each mode. [source: (City of Ottawa, 2015)] 16

Figure 4-1: Methodology for active transportation mobility demand modeling and infrastructure

assessment 26

$\begin{array}{lr}\text { Figure 5-1: Study Area Map } & 29\end{array}$

Figure 5-2: Road Network with Functional Classification. 30

Figure 5-3: Existing Traffic Demand in the intersections. 31

Figure 5-4: Cycling Infrastructure and Demand 32

Figure 5-5: Walking network and demand 33

Figure 5-6: Bike facilities in the North York Centre 34

Figure 5-7: A cyclist near Yonge St. and Sheppard Ave Intersection 34

Figure 5-8: Pedestrian waiting for the bus at the sidewalk 35

Figure 5-9: Insufficient Sidewalk Clear zone at Yonge St East side 35

Figure 5-10: Rapid Transit Corridor and Station Catchment areas with 600m and 800m buffer 36

Figure 5-11: School zone catchment area with 300 m buffer 37

Figure 5-12: Active mode connectivity measure for census zones. 38

Figure 5-13: Existing Pedestrian Level of Service 39

Figure 5-14: Existing Bike Level of Service 40

Figure 5-15: Existing Pedestrian demand on the links 41

Figure 5-16: Existing Bike Demand on the links 42 
Figure 5-17: Existing Mode share for evening peak period and trip distance up to $1 \mathrm{~km}$

Figure 5-18: Walking potential trips for census zones 44

Figure 5-19: Existing Mode share for evening peak period and trip distance 1-5 km 45

Figure 5-20: Cycling potential trips for census zones 46

Figure 5-21: Potential Pedestrian Demand $\quad 47$

$\begin{array}{ll}\text { Figure 5-22: Potential Cycling Demand } & 48\end{array}$

Figure 5-23: Pedestrian LOS for Potential Demand 49

Figure 5-24: Bike LOS for Potential Demand $\quad 50$

Figure 6-1: Existing Cross-section of Beecroft Rd at Sheppard Ave. W (Looking North) 53

Figure 6-2: Recommended Cross-section of Beecroft Rd at Sheppard Ave. W (Looking North) 53

Figure 6-3: Existing Cross-section of Yonge Street at Sheppard Ave. (Looking North) 54

Figure 6-4: Recommended Cross-section of Yonge Street at Sheppard Ave. (Looking North) 54

Figure 6-5: Existing Cross-section of Doris Ave. at Sheppard Ave. E (Looking North) 55

Figure 6-6: Existing Cross-section of Doris Ave. at Sheppard Ave. E (Looking North) 55

Figure 6-7: Existing Cross-section of Church St. at Doris Ave. (Looking West) 56

Figure 6-8: Recommended Cross-section of Church St. at Doris Ave. (Looking West) 56

Figure 6-9: Existing Cross-section of Park Home Ave. at Beecroft Rd. (Looking East) 57

Figure 6-10: Recommended Cross-section of Park Home Ave. at Beecroft Rd. (Looking East) 57 


\section{INTRODUCTION}

\subsection{Project Background}

Active transportation, generally recognized as walking and cycling and other active modes, plays a vital role for livable and equitable transportation solution by providing basic mobility, affordability, accessibility, first-and-last-mile connections, physical fitness and pleasure(Kuzmyak, Walters, Bradley, \& Kockelman, 2014). Due to its obvious health and environmental benefits to an individual as well as the whole society, planners, engineers, advocates in public agencies, private and non-profit organizations are eager to know potential demand and expand the active transportation infrastructure facilities to create sustainable living through complete streets design. Many public agencies on these cities are eager to expand the pedestrian and bicycle facilities or implementing complete streets or sustainable street design that provide safe and convenient connectivity for walking and cycling(Forsyth \& Krizek, 2012). Despite the widespread interest of building a sustainable or complete streets with more walking and cycling infrastructures, these remain limited and unimplemented due to lack of capacity and time to conduct detail analysis of active transportation demand (Forsyth, Agrawal, \& Krizek, 2012). Despite the recent policy and guidelines for promoting active transportation, the existing active travels are very uncommon in North American cities (Porter, Suhrbier, \& Schwartz, 1999).

Many researches focus on evaluating motorized vehicle conditions, however, a limited number of studies consider on vulnerable and non-motorized users, such as cyclist and pedestrian. The need for the improvement for pedestrian and bicyclist has received increase attention in recent years. Engineers and planners are recognizing the growing and popular interest in walking and bicycling especially from the young generations for many reasons including, cost efficient, convenience, health and environment reasons (Litman, 2017). On the other hand, due to the lack of pedestrian and cycling data and proper methodology, Engineers and planners are struggling to analyze priority of improvement or build a new facility. Moreover, many researches assisting public agencies are also done focusing on providing mobility of walking and cycling through better connectivity with a safe environment. However, they are not proving detailed or robust methodology by considering all aspects of multimodal transportation mobility, connectivity and safety (Forsyth \& Krizek, 2012). 
Many research and guidelines have already developed various methods to measure the pedestrian and bicycle level of service (LOS), connectivity, and safety overall (Kuzmyak, Walters, Bradley, \& Kockelman, 2014). However, those methods are separately measures the individual segments, intersections or mid-blocks and most of the cases it is applicable only for the existing conditions (Semler et al, 2016). Moreover, there is no methodology has been established to combine with potential demand and based on the demand what needs to be improved to accommodate this potential demand. This study focuses on finding out the overall active transportation potential demand, evaluate their infrastructure performance and recommend the improvement requirements in order to achieve the desired performance.

\subsection{Scope and Objectives}

The $t$ goal of the project was to develop a robust methodology framework to guide planners and engineers for assessing the performance and needs of the active transportation facilities, based on their existing and potential demand through integration of widely used methods. In addition, scope of the project included recommending a new street design in order to accommodate the potential active transportation network demand, based on the sustainable streets design guidelines.

Specific objectives of this study were as below.

- Analyze the existing active transportation demand, mobility pattern, and connectivity.

- Measure network performance for Walking and Bicycling in the corridor including streets segments and signalized intersections.

- Estimate and analyze the potential travel demand for the pedestrian and bicycle users and thereafter to assign in the local network.

- Determine the requirement of the infrastructure improvement in the context of potential and overall network demand. 


\subsection{Report Organization}

This report is organized as follows:

Chapter 1 highlights the study background, aims and objectives of the project.

Chapter 2 presents a literature review that reveals the benefits and potential for using active transportation. Also discusses the factors that affect the active transportation mode choice and active transportation performance assessment based on Level of Service.

Chapter 3 discusses modeling framework and briefly summarizes the existing models that can evaluate the active transportation demand and infrastructure performance.

Chapter 4 presents the methodology and data collection required for the case study.

Chapter 5 presents the Case Study analysis and results through implementing the integrated comprehensive methodology.

Chapter 6 describes existing street cross-section design and recommended design. According to the local and international standards, guidelines for walking and cycling facilities, this chapter presents the inclusive street design to create a livable environment for area residents and visitors.

Chapter 7 summarizes the overall project achievements, limitations, and further study areas. 


\section{LITERATURE REVIEW}

\subsection{Benefits and Potential of Active TransportationMode Choice}

There are numerous benefits of using active transportation as individual and society overall including health benefits, connecting other modes of transportation, walking and cycling activity can reduce auto mode share provides benefit to the society by alleviating congestions and other road related cost, and more compact and multimodal development. Active modes are a critical component in transportation systems and typically this is the second most common modes of all transportation that provides access to and connections among other modes of transportation (Litman, 2017). Practically, every transit trip starts and ends with a walk to/from the transit stop, so walking and cycling provides access to public transit and the best way to improve and encourage public transit travel is to improve local walking and cycling conditions (Litman, 2017). Moreover, it is desired that everybody needs to walk for some parts of their trip making even though they are using auto modes, walking provides connections between parked vehicles and destinations, so pedestrian improvements can help reduce parking problems.

Since the active transportation are human powered, it provides unique benefits in significant health improvement to the users. Even though there are lot ways to be physically active, walking and cycling are the most practical and effective way, particularly for inactive and overweight people. A recent study found that rates of overweight, obesity and diabetes tend to decline with neighborhood walkability (Creatore et al, 2016).Regular walking and cycling reduces the risk of heart disease and obesity (Toronto Public Health, 2012). The society could also get benefited at large through lowering healthcare costs. In addition, these health benefits extend the life of those who regularly walk and cycle which is considered as the biggest possible benefit for the whole society (Metrolinx and steer davis gleave, 2015).

Apart from the health benefits of using Active modes of transportation, walking and cycling can also help reducing congestions of the transportation systems. The impact of traffic congestion is significant in urban areas in North American cities, especially Greater Toronto Hamilton Area (GTHA). So, modal shift from the auto users to potential active transportation may contribute significantly to reduce the traffic congestion. Active transportation users can substantially reduce car uses and thereby the expenditure related to roadways such as, adding new lanes for higher pressure of traffic, road maintenance, and safety enhancements would be minimized. As a consequence, shift to active modes 
can significantly reduce the capital and operating cost for the roadways. In addition, developing and maintaining a new bike and pedestrian infrastructure facilities are considerably less costly than the construction and maintaining roadway facilities for auto users. For instances, a new bike lane costs approximately $\$ 20,000 / \mathrm{km}$ if no road widening is required and $\$ 150,000 / \mathrm{km}$ if it requires widening. On the contrary, it will take approximately $\$ 800,000 / \mathrm{km}$ to widen from two lanes to four lanes urban arterial road (Metrolinx and steer davis gleave, 2015).

In addition, bike lanes and sidewalks provide relatively higher capacity than vehicle travel lanes. For example, a typical vehicle lane can accommodate less than $1000 \mathrm{veh} / \mathrm{hr}$; in contrast, a bike lane can accommodate up to 2500 bikes/ hr. and a standard sidewalk of $2.1 \mathrm{~m}$ width, pedestrian capacity is also approximately $2000 \mathrm{ped} / \mathrm{hr}$ (HCM, 2010)(Metrolinx and steer davis gleave, 2015). In overall, the development of active transportation also generates roadway operating savings. By comparing to the motorized vehicles, bicycles are very light vehicles, causing very minor wear and tear of the roads, so does pedestrian pressure for the sidewalk. This increases roadway life, and reduces annual rehabilitation costs.

Active transportation infrastructure is also favorable for local businesses improvement. As cyclists and pedestrians can easily move around more often than drivers, so they are more likely to spend their money at local destinations and this is the way the local economic activity increases within their community by increasing revenue for local business. A recent study consumer behavior and travel choice found that people who bike and walk to an area spend more money in the area per month than those who drive there (Clifton et al., 2013). Sometimes a neighborhood livability, property values and retail activity would be increased due to reducing the motorized traffic and adding more active transportation facilities which makes the streets more sustainable and environmental friendly.

Cycling and walking facilities are effective in creating appealing places and encourage greater active transportation for everyday trips, and thus contributing to economic viability of the community and increasing real estate value and retail activity. Moreover, the more active transportation uses reduce the parking demand, so the land can be freed up and made available for some other economic productive purposes. 
Active transport is one of the cheapest modes of transportation for individual living in the urban areas. The high car price, insurance, oil and parking cost makes transportation is the second major item of expenses for a typical household after their housing cost. An average auto user operating cost is 27 cents $/ \mathrm{km}$, whereas a cycling operating cost is only 5.7 cents / $\mathrm{km}$ which is almost 5 times lower than auto users cost (Litman \& Eric, 2011)(Metrolinx and steer davis gleave, 2015). The cost of walking is essentially zero, so higher active trnasportation uses means the lower motor vehicle use that saves a lot of households/ individual money where households can also able to eliminate a second car.

. For walking the short trip can be defined as upto $1 \mathrm{~km}$ trip distance which is around 10 min walking distance, and for cycling the trip distance could be upto $4 \mathrm{~km}$ which is roughly takes 20 min by bike(Kuzmyak, Walters, Bradley, \& Kockelman, 2014). Sometimes active transportation could be quicker than motorized modes for short distance trips. People tend to overestimate how long it takes them to get around by foot, but underestimate the time it takes to drive. A study has been conducted by the center of transportation studies, University College London, UK on why people are currently using their cars for the short trips. The survey car users for short trips shows that almost $40 \%$ percent users, who is now using car, believe that his/her trips could be made by walking or cycling(Mackett, 2003) .

\subsection{Factors Affecting Active Transportation Demand and Modeling}

Active transportation demand depends upon several factors in different areas, such as, demographic, economic, and land use factors. The factors that contribute the active transportation demand are summarized in Table 2-1. Among socio-demographic characteristics age plays a vital role, such as youth and strong can walk and cycle further than the old people. Mostly lower income people who don't own a car have higher possibility of take a walk or bike. Walking and cycling facilities are the vital factors to choose these modes of transportation. Trip distance and land use characteristics are also other most important variables to consider active mode - short trip distance and less variation in land use favor active mode. Besides these factors, the climate or weather condition is one of the most crucial factors for active transportation mode choice. A recent research in weather impacts on work trip mode choice shows that temperature and precipitation have significant effect on transportation mode choice. An increase of temperature by $6 \%$ can enhance cycling trips by $17 \%$ and reduce the auto-passenger trips by 7\% (Saneinejad, Roorda, \& Kennedy, 2012). 
Table 2-1: Factors those impacts on the Active Transportation Demand [Source: (Litman, 2017) ]

\begin{tabular}{|c|c|}
\hline Factors & Impacts on Active Travel \\
\hline Age & $\begin{array}{l}\text { Young people tend to have high rates of walking and cycling. Some older people have } \\
\text { high rates of walking for transportation and exercise. }\end{array}$ \\
\hline Physical Ability & $\begin{array}{l}\text { Some people with impairments rely on walking and cycling, and may require facilities } \\
\text { with suitable design features, such as ramps for walkers and wheelchairs. }\end{array}$ \\
\hline $\begin{array}{l}\text { Income and } \\
\text { Education }\end{array}$ & $\begin{array}{l}\text { Many lower-income people tend to rely on active modes for transportation. Bicycle } \\
\text { commuting is popular among higher income professionals. }\end{array}$ \\
\hline Dogs & Daily walking trips tend to be higher in households that own dogs. \\
\hline $\begin{array}{l}\text { Vehicles and } \\
\text { Drivers } \\
\text { Licenses }\end{array}$ & $\begin{array}{l}\text { People who do not have a car or driver's license tend to rely on walking and cycling for } \\
\text { transportation. }\end{array}$ \\
\hline Travel Costs & Active travel tends to increase with driving costs (parking fees, fuel taxes, road tolls, etc.) \\
\hline Facilities & $\begin{array}{l}\text { Walking and cycling activity tend to increase where there are good facilities (sidewalks, } \\
\text { crosswalks, paths, bike racks, etc.) }\end{array}$ \\
\hline $\begin{array}{l}\text { Roadway } \\
\text { Conditions }\end{array}$ & $\begin{array}{l}\text { Walking and cycling tend to increase in areas with narrower roads and lower vehicle } \\
\text { traffic speeds. }\end{array}$ \\
\hline Trip Length & Walking and cycling are most common for shorter (less than 2-mile) trips. \\
\hline Land Use & $\begin{array}{l}\text { Walking and cycling tend to increase in areas with compact and mixed development } \\
\text { where more common destinations are within walking distances. }\end{array}$ \\
\hline Promotion & $\begin{array}{l}\text { Walking and cycling activity may be increased with campaigns that promote these } \\
\text { activities for health and environmental improvement sake. }\end{array}$ \\
\hline IDllc support & cling rates tend to increase where communities consider it socially acceptable. \\
\hline
\end{tabular}

Different methods used for measuring active transportation demand include travel surveys, and volume counts for pedestrian and cycling in the streets. Conventional methods of travel data collection may provide less than the actual number of active transportation trips because most of the surveys do not consider short trip or trips within the traffic analysis zone (TAZ), off-peak trips, non-work trips, travel by children, recreational travel, etc. (Litman, 2017). For instance, Transportation Tomorrow Survey (TTS) data in GTHA considers pedestrian mode choice data for only work trip purpose (Data Management Group, 2011). In addition, TTS data ignore active mode links to other motorized vehicle trips, such as, a bike-transit-walk trips often considers as a transit trip and a car user who walk several blocks to/from the parked car is classified as an auto trip (Litman, 2017)(Data Management Group, 
2011). However, the comprehensive surveys indicate that the actual active travel is three to six times higher than the results found in the conventional surveys (Forsyth, Agrawal, \& Krizek, 2012). Survey reveals that entirely walking constitutes only $7 \%$ of Canadian urban commutes and about $20 \%$ commutes include a walking link; whereas, in Germany, 22\% of trips are completely walking and 70\% includes walking links (Litman, 2011). He indicated that if any survey statistics shows 5\% of total trips are active mode, the actual figure could be between 10-30\%.

\subsection{Active Transportation Performance Measure: Level of Service}

Among different methods for measuring the performance of active transportation movement, Level of Service (LOS) is widely used in Transportation Engineering. Highway Capacity Manual (HCM) uses the concept of level of service as a qualitative measure to describe operational conditions of any transportation modes including, pedestrian and bicycling traffic, based on service measures such as, speed and travel time, delay, freedom to maneuver, traffic interruptions, comfort and convenience (HCM, 2010).For instances, according to the HCM methods, Pedestrian LOS are measured based on the pedestrian flow rate and space of the sidewalk. The pedestrian flow rate, pedestrian speed, density, and volume, are the criteria considered for the LOS measurement. The foremost advantage of the HCM pedestrian LOS methodology is its simplicity, although it doesn't consider some important factors, such as, the individual pedestrian characteristics, surrounding land uses, environmental impact, trip purpose, etc,. (New York City, 2006).

Table 2-2: Pedestrian Level of Service Criteria for Sidewalks and Walkways [Source: (HCM, 2000)]

\begin{tabular}{|c|c|c|c|c|c|c|c|}
\hline \multirow[t]{2}{*}{ LOS } & \multicolumn{2}{|c|}{ Space } & \multicolumn{2}{|c|}{ Flow Rate } & \multicolumn{2}{|c|}{ Average Speed } & \multirow[t]{2}{*}{$\mathrm{v} / \mathrm{c}$ ratio } \\
\hline & $\left(\mathrm{m}^{2} /\right.$ ped $)$ & $\left(\mathrm{ft}^{2} /\right.$ ped $)$ & $(\mathrm{ped} / \mathrm{min} / \mathrm{m})$ & (ped/min $/ \mathrm{ft})$ & $(\mathrm{m} / \mathrm{s})$ & $(\mathrm{ft} / \mathrm{min})$ & \\
\hline $\mathbf{A}$ & $\geq 5.6$ & $\geq 60$ & $\leq 16$ & $\leq 5$ & $\geq 1.3$ & $\geq 255$ & 0.21 \\
\hline B & $3.7-5.6$ & $40-60$ & $16-23$ & $5-7$ & $1.27-1.30$ & $250-255$ & $0.21-0.31$ \\
\hline C & $2.2-3.7$ & $24-40$ & $23-33$ & $7-10$ & $1.22-1.27$ & $240-250$ & $0.31-0.44$ \\
\hline D & $1.4-2.2$ & $15-24$ & $33-49$ & $10-15$ & $1.14-1.22$ & $225-240$ & $0.44-0.65$ \\
\hline $\mathbf{E}$ & $0.75-1.4$ & $8-15$ & $49-75$ & $15-23$ & $0.75-1.14$ & $150-225$ & $0.65-1.0$ \\
\hline $\mathbf{F}$ & $\leq 0.75$ & $\leq 8$ & variable & variable & $\leq 0.75$ & $\leq 150$ & variable \\
\hline
\end{tabular}



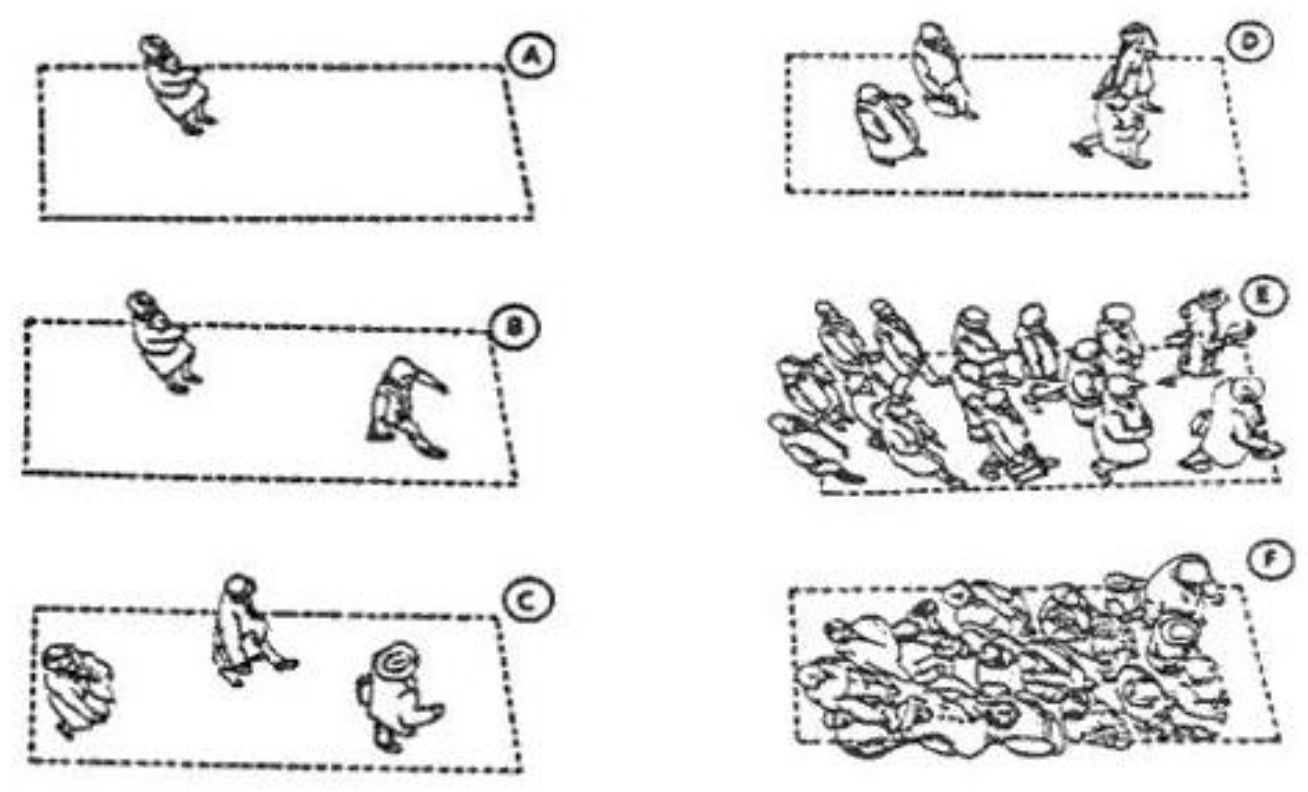

Figure 2-1: Pedestrian LOS [source:(HCM, 2000)]

LOS is measured using the letter grade from A to F, where LOS A refers to free flow conditions that means no delays, very comfortable, convenience and safe; on the other hand, LOS F refers to Severe conditions indicating long delay and very unpleasant for any modes of transportation. According the HCM,

- Pedestrian LOS A, where the flow is less than or equal to $16 \mathrm{ped} / \mathrm{min} / \mathrm{m}$, represents that pedestrians move at the Sidewalk or walkway in desired paths without altering their movements in response to other pedestrians. Walking speeds are considered as the free-flow, and there is no possibility of conflicts between the pedestrians.

- Pedestrian LOS B, where flow is $16-23 \mathrm{ped} / \mathrm{min} / \mathrm{m}$, represents that there is sufficient area for pedestrians to select walking speeds freely to bypass other pedestrians, also to avoid crossing conflicts. At this level, pedestrians realize the existence of other pedestrians.

- Pedestrian LOS C, where the flow is $23-33 \mathrm{ped} / \mathrm{min} / \mathrm{m}$, represents that the space is sufficient for normal walking speeds, and for bypassing other pedestrians in primarily unidirectional streams. At this level, the crossing movements can cause minor conflicts, and speeds and flow rate are somewhat lower.

- Pedestrian LOS D, where the flow is the33-49 $\mathrm{ped} / \mathrm{min} / \mathrm{m}$, represents that the individual walking speed and to bypass other pedestrians is restricted. Moreover, the crossing or reverseflow movements face a high probability of conflict, changes in speed and position. At this level, the flow is reasonable; however, friction and interaction between pedestrians are likely. 
- Pedestrian LOS E, where the flow is the $49-75 \mathrm{ped} / \mathrm{min} / \mathrm{m}$, represents that all pedestrians restrict their normal walking speed, frequently adjusting their pace or movement. The walking space is not sufficient for passing slower pedestrians and crossing or reverse-flow movements are possible only with extreme difficulties. The design pedestrian volumes approach the limit of walkway capacity, with stoppages and interruptions to pedestrian flow.

- Pedestrian LOS F, where flow is greater than $75 \mathrm{ped} / \mathrm{min} / \mathrm{m}$, all walking speeds are severely restricted, and forward progress is made only by shuffling. There is frequent unavoidable contact with other pedestrians. Cross-and reverse-flow movements are virtually impossible. Flow is sporadic and unstable. 


\section{MODELING FRAMEWORK}

The complex nature of active transportation systems is difficult to evaluate by only one specific method (Semler et al., 2016). Several performance methods that can be used for the evaluation of the quality of active transportation conditions are discussed below.

\subsection{Proximity Analysis to Major Destinations}

The proximity to major destinations is important consideration for active transportation mode choice. Major destinations include community facilities, such as, parks, schools, universities; and transportation facilities, such as, bus stops, rapid transit stations.. These areas are highly potential the major attractions to the pedestrians and bicycle users. Proximity measures can be calculated as straight line distance or the crow flying distance where this method assumes that a destination may be accessed equally from all sides. Most of the researches are based on a simple spatial analysis in ArcGIS software used to measure the proximity by creating a buffer around the point or line layer and thus analyze the performance of active transportation. However, a network analysis tools in ArcGIS allows for more reliable distance calculations. A variety of ways mentioned below could be used in conducting this method depending on the data availability and project need to analyze the existing and potential active transportation performance (Semler et al., 2016).

- Proportion of people within $800 \mathrm{~m}$ walking distance or around $3 \mathrm{~km}$ biking distance to specific key destinations, such as parks or elementary schools.

- Proportion of people within $800 \mathrm{~m}$ walking distance or around $3 \mathrm{~km}$ biking distance to specific key destinations along a completed pedestrian or bicycle facility.

- Proportion of people with access to a predefined set of "community destinations" within a 10minute walk or 20-minute bike ride.

- Percent of the network complete for pedestrians and bicyclists within $800 \mathrm{~m}$ walking distance or around $3 \mathrm{~km}$ biking distance.

- Number of destinations that can be accessed within $800 \mathrm{~m}$ walking distance or around $3 \mathrm{~km}$ biking distance from a given point on the network.

- Number of destinations within $5 \mathrm{~km}$ along a bicycling network from a given point on the network. 


\subsection{Connectivity Index}

Connectivity means the diverse ways to get from one place to another by using different modes of transportation, such as, by foot, bicycle, transit or car (The City of Calgary, 2010). The Victoria Transport Policy Institute states that, "Connectivity refers to the directness of links and the density of connections in path or road network. A well-connected road or path network usually has many short links, numerous intersections, and minimal dead ends (cul-de-sacs). As connectivity increases, travel distances decrease and route options increase, allowing more direct travel between destinations, creating a more accessible and resilient system"(Victoria Transport Policy Institute , 2010). Researchers found that increased connectivity has number of benefits including (The City of Calgary, 2010).

- Improving the public health by providing walking and cycling as a sustainable transportation option.

- Enhancing the accessibility to the arterial and collector streets and reducing delays for motorist.

- Reducing the walking distances to / from the transit stops.

In urban areas, street network concepts have traditionally hierarchical with local, collector and arterial streets, designed mostly with the primary purpose of funneling automobile traffic. The cul-de-sacs and dead ends are extensively used in this kind of roadway design to provide mostly mobility to the car users. However, the more connected road systems provide a greater number of route options that make bicycling and walking more pleasant and convenient. Moreover, it is difficult to bicycle and walk safely and comfortably around a community where connections are few. The Figure 3-1 shows difference between different types of street network such as, grid-iron pattern curvilinear street network. 
Table 3-1: Types of Connectivity measures [Source: (Semler et al., 2016)]

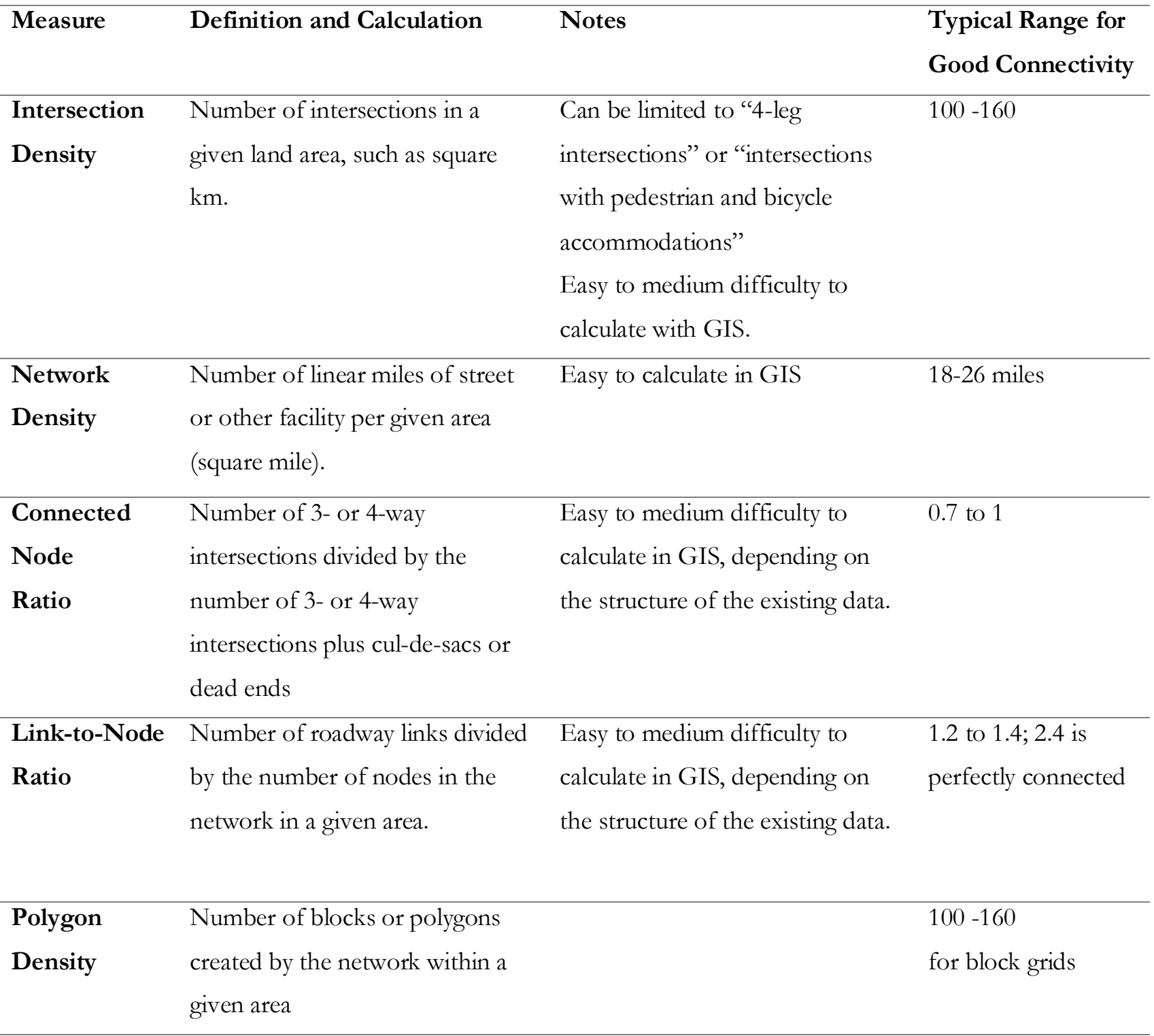

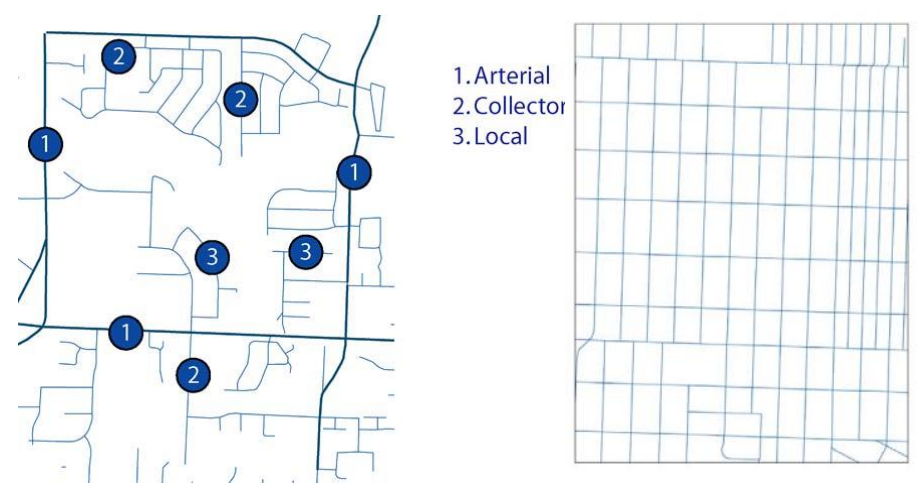

Figure 3-1: Types of different Road network. [Source: (The City of Calgary, 2010)] 
The Calgary Transportation Plan-Connectivity Handbook uses Link-Node Ratio to measure the Connectivity Index (The City of Calgary, 2010). The connectivity Index is calculated by using the ratio of street links (streets between intersections, or cul-de-sacs) to street nodes. Connectivity index includes all types of streets, however, alleys, driveways or private accesses are not considered for the calculation. A sample of connectivity index calculation is displayed by the figure 2 and corresponding calculation are below:

- $\quad$ Street Connectivity Index $=$ \# of Links / \# of Node $=29 / 18=1.61$

- Active mode connectivity index $=$ \# of Links $/$ \# of Node $=47 / 25=1.88$
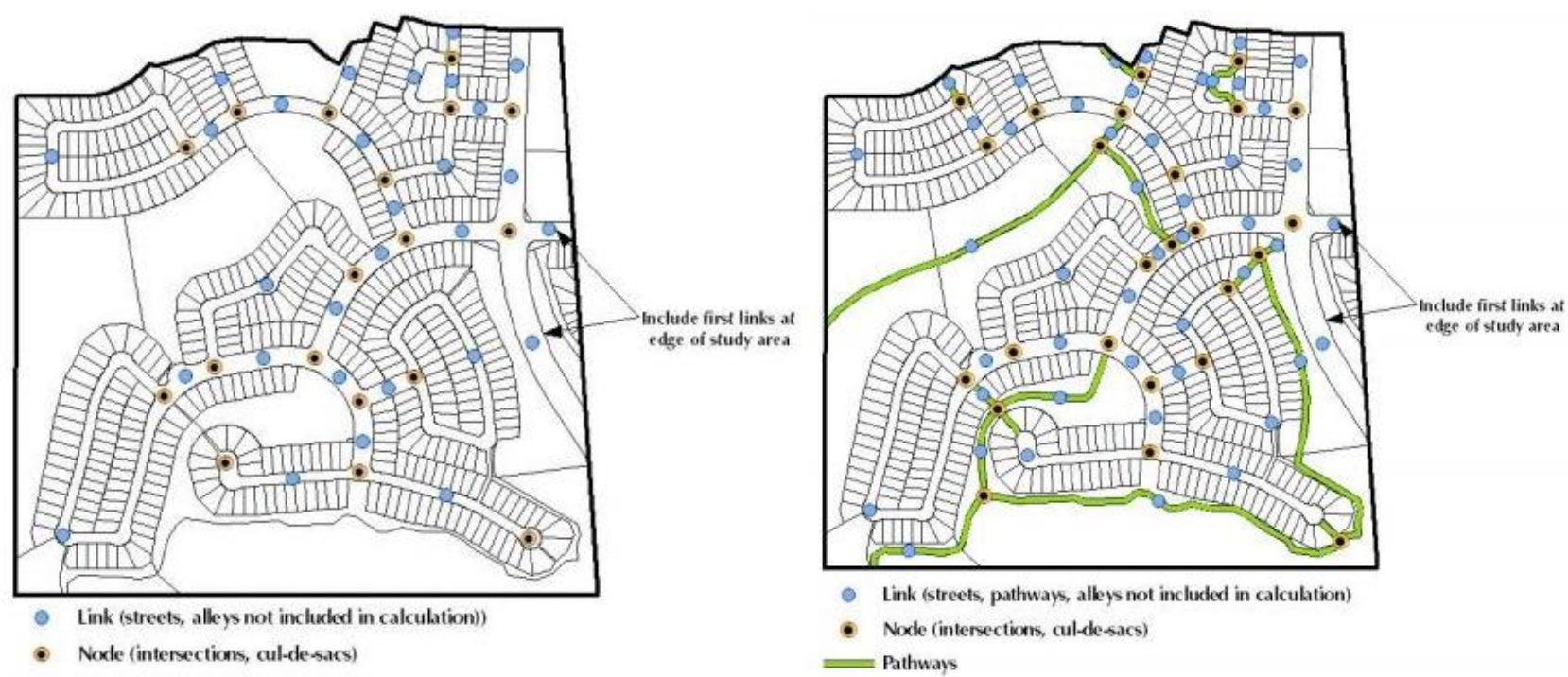

Figure 3-2: Connectivity Index Sample Calculation. [Source: (The City of Calgary, 2010)]

Depending on the street patterns the connectivity indices varies. According to the threshold level, used in the Calgary Connectivity Index Handbook, the streets in grid-iron pattern have complete connectivity, whereas curvilinear is the lower connective network (The City of Calgary, 2010). Figure 3-3 shows the desirable index zone for any area which includes Fused-Grid networks and Major Community Activity Centre. 


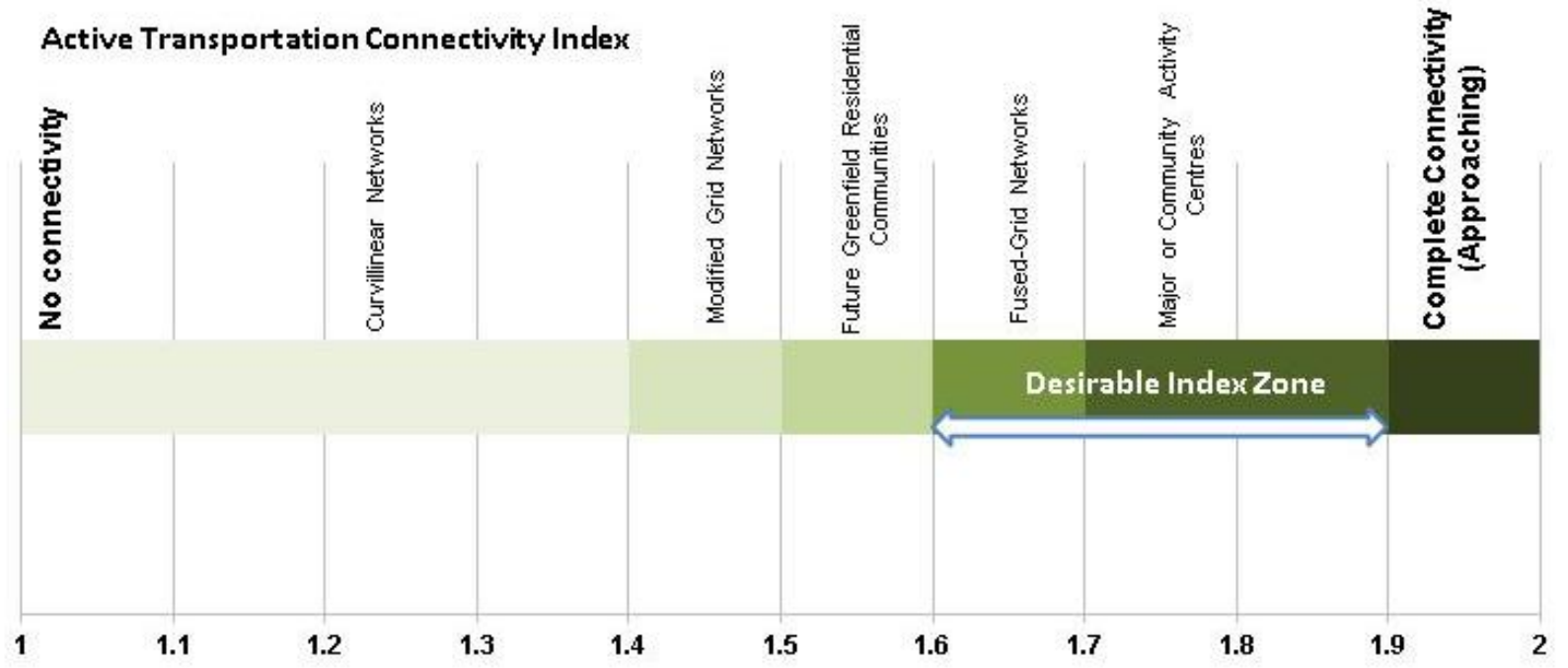

Figure 3-3: Active Transportation Connectivity Index threshold.

\subsection{Multimodal Level of Service (LOS) Method}

Multimodal Level of Service (MMLOS) focuses on all modes of transportation to understand how design choices impact the performance or quality of each user - pedestrian, cyclist, transit rider, motorist, or truck driver. City of Ottawa has recently developed a MMLOS guideline that provides guidance to practitioners (City staff, consultants, etc.) on how to assess the various LOS for the different modes of transportation. Corresponding specific target service/LOS levels for each mode should be given based on the land use or location and the context of the transportation project (City of Ottawa, 2015). This method is relatively simpler than the HCM approach, where, segments are considered as one signalized intersection to another. Although the LOS methodology enables trade-offs to be made between modes, it is still important to consider the scales of each mode as independent from one another. This study analyzes pedestrian and bicycle modes which have been discussed below in detail. Figure 3-4 below shows the whole range of service levels under different modes. 


\begin{tabular}{|c|c|c|c|}
\hline \multirow{2}{*}{ MODE } & \multirow{2}{*}{ ELEMENT } & \multicolumn{2}{|c|}{ LEVEL OF SERVICE } \\
\hline & & B & D \\
\hline \multirow{2}{*}{$\begin{array}{l}\text { Pedestrians } \\
\text { (PLOS) }\end{array}$} & Segments & High level of comfort & Low level of comfort \\
\hline & Intersections & Short delay, high level of comfort, low risk & Long delay, low level of comfort, high risk \\
\hline \multirow{2}{*}{$\begin{array}{c}\text { Bicycles } \\
\text { (BLOS) }\end{array}$} & Segments & High level of comfort & Low level of comfort \\
\hline & Intersections & Low level of risk / stress & High level of risk / stress \\
\hline \multirow{2}{*}{$\begin{array}{l}\text { Trucks } \\
\text { (TkLOS) }\end{array}$} & Segments & Unimpeded movement & Impeded movement \\
\hline & Intersections & Unimpeded movement / short delay & Impeded movement / long delay \\
\hline \multirow{2}{*}{$\begin{array}{l}\text { Transit } \\
\text { (TLOS) }\end{array}$} & Segments & High level of reliability & Low level of reliability \\
\hline & Intersections & Short delay & Long delay \\
\hline Vehicles (LOS) & Intersections & Low lane utilization & High lane utilization \\
\hline
\end{tabular}

Figure 3-4: MMLOS ranges for each mode. [source: (City of Ottawa, 2015)]

\subsubsection{Pedestrian Level of Service (PLOS)}

The main purpose of the Pedestrian Level of Service (PLOS) tool is to evaluate pedestrian comfort, safety and convenience (City of Ottawa, 2015) and the following Table 3-2 listed all the parameters used. The corridor is divided into different segments and signalized intersections. The criteria include the both operational and geometric characteristics in the segment and the signalized intersection. For segment analysis, the operational parameters are vehicle speed, volume per lane, and geometric parameters including sidewalk width, boulevard width, and on-street parking facilities. On the other hand, signalized intersection is based on the two separate methods.

- Pedestrian Exposure to Traffic Signalized Intersections (PETSI): Pedestrian at signalized intersection evaluates based on the PETSI score. The PETSI is the most data intensive approach, where each movement is evaluated separately using the parameters that include total street width, turning conflicts, corner radius and crosswalk treatment. Worst approach score is taken into account as the final evaluation of the intersection..

- Average Delay: Average delay to pedestrians crossing the street is evaluated by the Highway Capacity Manual (HCM) method based on a simple equation using cycle length and pedestrian green time (walk time).

The parameters considered for analysis of the pedestrian level of service for the streets segment and signalized intersections are summarized in the Table 3-2 below. The segments or links LOS consider 
vehicle operating speed, sidewalk and boulevard width, auto AADT per lane and existence of onstreet car parking facilities. On the other hand, signalized intersection LOS measure considers both geometric and operational characteristics of the road. Geometric characters include street width, number of lanes, right turn channelization, crosswalk type; and operational characteristics include signal phasing system, and whether protective/permissive and pedestrian phase exist or not.

Model is sensitive to the combination of all impeding characteristics for the pedestrian to feel safe in the sidewalk environment such as (City of Ottawa, 2015),

- If vehicle operating speed increases the pedestrian comfortability, safety decreases.

- If the Sidewalk width increases the pedestrian comfortability increases, so does with boulevard width.

- Traffic volume is categorized by either low or high using the threshold value 300 AADT. Higher traffic on the street means lower comfortable for pedestrian.

- On Street parking impact s are just considered as whether it presents. Parking presence always gives more comfortable and safety for the pedestrian in the sidewalk and that's why the LOS increases.

Table 3-2: Criteria that are considered for the PLOS tools. [Source: (City of Ottawa, 2015)]

\begin{tabular}{|c|c|}
\hline SEGMENTS & SIGNALIZED INTERSECTIONS \\
\hline 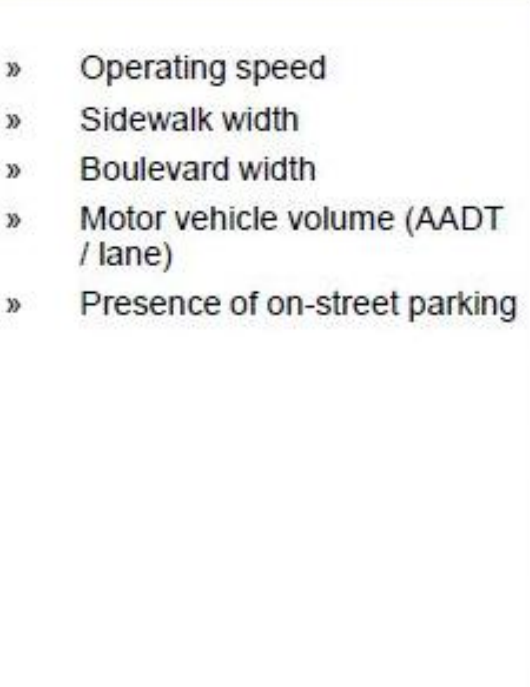 & $\begin{array}{l}\text { Exposure to Traffic } \\
\text { " Street width (number of through lanes to be crossed - } \\
\text { with or without a median) and presence of refuge } \\
\text { island for crossing pedestrians } \\
\text { " Right \& left turn conflicts based on phasing (permitted, } \\
\text { protected/permitted, protected, prohibited) and } \\
\text { pedestrian-only phases (leading pedestrian interval) } \\
\text { Right turn on Red (RTOR) restrictions } \\
\text { " Corner radius and type (smart right turn channel, right } \\
\text { turn channel with receiving lane) } \\
\text { Crosswalk treatment (transverse marking, zebra stripe } \\
\text { markings, textured/coloured crosswalks, raised } \\
\text { crosswalks) } \\
\text { Delay } \\
\text { " Cycle length } \\
\text { Pedestrian green time (walk time) }\end{array}$ \\
\hline
\end{tabular}


Table 3-3: Pedestrian LOS Criteria and value. [source: (City of Ottawa, 2015)]

\begin{tabular}{|c|c|c|c|c|c|c|c|}
\hline \multirow{3}{*}{$\begin{array}{l}\text { Sidenalk Whith } \\
\text { (in) }\end{array}$} & \multirow{3}{*}{$\begin{array}{l}\text { Boulevard Writh } \\
\text { (m) }\end{array}$} & \multirow{3}{*}{$\begin{array}{l}\text { Motar Vhtide } \\
\text { Traffic Volume } \\
\text { (AMDT) }\end{array}$} & \multirow{3}{*}{$\begin{array}{l}\text { Presence of On- } \\
\text { strest Pathing }\end{array}$} & \multicolumn{4}{|c|}{ Segnent PLOS } \\
\hline & & & & \multicolumn{4}{|c|}{ Operating Speed (kmih) } \\
\hline & & & & $\leq 0$ & $>30$ or 50 & $\times 50$ or $60^{\circ}$ & $>\infty^{1}$ \\
\hline \multirow{9}{*}{2.0 or more } & \multirow{3}{*}{$>2$} & $\leq 3000$ & NA & A & A & A & B \\
\hline & & \multirow{2}{*}{$>3000$} & Yes & A & B & 8 & NAA \\
\hline & & & No & $A$ & B & c & 0 \\
\hline & \multirow{3}{*}{0.5 to 2} & $\leq 3000$ & NA & $A$ & A & A & B \\
\hline & & \multirow{2}{*}{$>3000$} & Yes & A & B & $c$ & NAA \\
\hline & & & No & A & c & 0 & E \\
\hline & \multirow{3}{*}{$\theta$} & $\leq 3000$ & NA & A & $B$ & c & 0 \\
\hline & & \multirow{2}{*}{$>3000$} & Yes & 8 & $B$ & 0 & NAA \\
\hline & & & No & 8 & c & $E$ & $F$ \\
\hline \multirow{9}{*}{1.8} & \multirow{3}{*}{$>2$} & $\leq 3000$ & NA & $A$ & $A$ & $A$ & $B$ \\
\hline & & \multirow{2}{*}{$>3000$} & Yes & A & $B$ & c & $\mathrm{N} / \mathrm{A}$ \\
\hline & & & No & A & $c$ & 0 & $E$ \\
\hline & \multirow{3}{*}{0.5 to 2} & $\leq 3000$ & NA & A & B & 8 & 0 \\
\hline & & \multirow{2}{*}{$>3000$} & Yes & $A$ & $c$ & c & $N A$ \\
\hline & & & No & 8 & c & $E$ & $E$ \\
\hline & \multirow{3}{*}{0} & $\leq 3000$ & NA & $A$ & B & c & 0 \\
\hline & & \multirow{2}{*}{$>3000$} & Yes & 8 & $c$ & 0 & NAA \\
\hline & & & No & $c$ & 0 & $F$ & $F$ \\
\hline \multirow{7}{*}{1.5} & \multirow{3}{*}{$>2$} & $\leq 3000$ & NA & $c$ & $c$ & c & c \\
\hline & & \multirow{2}{*}{$>3000$} & Yes & $c$ & $c$ & 0 & NAA \\
\hline & & & No & c & 0 & $E$ & $E$ \\
\hline & \multirow{3}{*}{0.5 to 2} & $\leq 3000$ & NA & c & c & $c$ & 0 \\
\hline & & \multirow{2}{*}{$>3000$} & Yes & c & $c$ & 0 & NAA \\
\hline & & & No & 0 & $\bar{E}$ & $E$ & $E$ \\
\hline & 0 & \multicolumn{2}{|c|}{ NA } & 0 & $E$ & $F^{2}$ & $\bar{F}$ \\
\hline$<1.5$ & \multicolumn{3}{|c|}{ NA } & $\overline{F^{3}}$ & $\overline{F^{3}}$ & $F^{3}$ & $F^{3}$ \\
\hline No sidewalk & \multicolumn{3}{|c|}{ NA } & $c^{4}$ & $F^{2}$ & $F^{2}$ & $F^{3}$ \\
\hline
\end{tabular}




\subsubsection{Bicycle Level of Service (BLOS)}

According to the Ottawa MMLOS guidelines, the Bicycle Level of Service (BLOS) method can be used to evaluate both roadway segments and signalized intersections for the stress level experienced by the cyclists (City of Ottawa, 2015). The method can evaluate the degree of comfort experienced by cyclists and targeted users, whether there are existing cycling facilities or not. Therefore, this method provides support and justification for the infrastructure improvements that may attract the new cyclists (City of Ottawa, 2015). In case of no cycling facilities, the method needs data on the number of total lanes (both ways) and operating speed on the roadway. The methodology is more applicable to the urban/suburban context; however, proper assumptions or judgment is necessary when we need to use this methodology to the facility types not mentioned here. This methodology also considers the score of the weakest link for evaluating corridors and intersections. For instances, if any link or approach has got the score LOS F, the overall LOS for the segment/intersection is considered as the LOS F, regardless of better scores in other links or approaches. Data requirements with the corresponding segment and intersections are illustrated in Table 3-4.

Since it is not possible to achieve LOS A for all modes in the street due to the scarcity of land and funding, in addition, it is not cost efficient or effective uses to provide LOS A for all modes in a street. Therefore, the ultimate target is to set a guidelines or desired LOS target for the different street types surrounding by different land use designation areas such as, central business district (CBD), urban centers and policy areas such as, near to rapid transit station or schools. For instances, according to City of Ottawa MMLOS guidelines, the desired level of service for pedestrian and bicycle are A and C respectively in mixed use center and within the $600 \mathrm{~m}$ of transit station the LOS for both pedestrian and bicycle are $\mathrm{A}$ and $\mathrm{B}$ accordingly. 
Table 3-4: Criteria considered for the Bicycle LOS measure [Source: (City of Ottawa, 2015)].

\begin{tabular}{|c|c|}
\hline SEGMENTS & SIGNALIZED INTERSECTIONS \\
\hline $\begin{array}{l}\text { Mixed Traffic (No cycling facility) } \\
\text { - Street width (total number of lanes in both } \\
\text { directions) } \\
\text { - Vehicular operating speed } \\
\text { Bike Lanes } \\
\text { - Street width (number of through lanes per } \\
\text { direction) } \\
\text { - Bike lane width (including marked buffer and } \\
\text { paved gutter width) } \\
\text { - Parking lane width (where bike lane is adjacent } \\
\text { to parking lane) } \\
\text { - Vehicular operating speed } \\
\text { - Qualitative assessment of commercial deliveries } \\
\text { for commercial areas } \\
\text { Physically Separated Bikeway (includes cycle } \\
\text { tracks, protected bike lanes and multi-use paths) } \\
\text { - No additional information needed } \\
\text { Un-signalized Crossings } \\
\text { - Presence of median refuge suitable for bicycle } \\
\text { storage ( } \geq 1.8 m \text { wide) } \\
\text { - Width of street being crossed (number of lanes in } \\
\text { both directions) } \\
\text { - Speed limit of street being crossed }\end{array}$ & 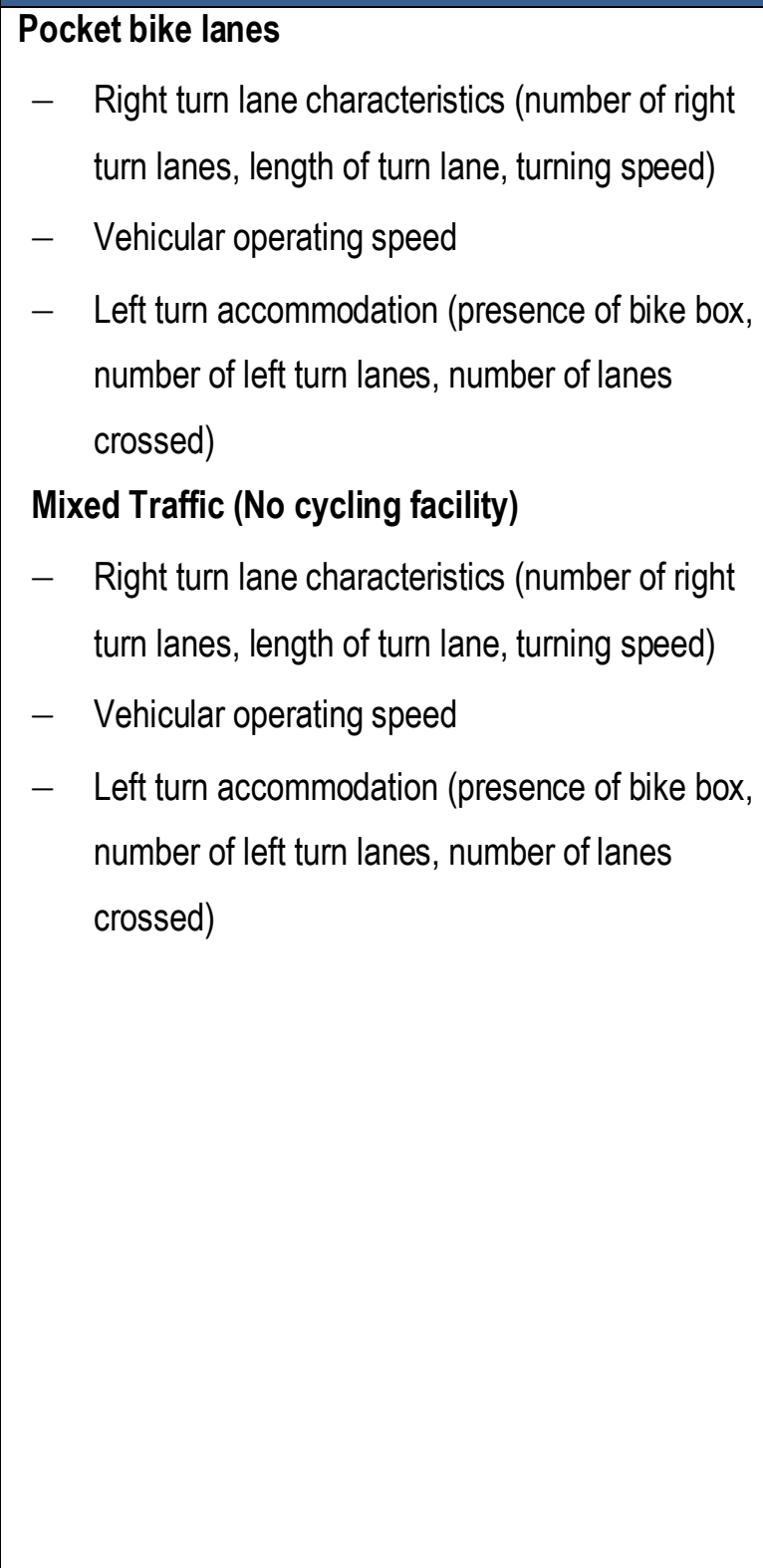 \\
\hline
\end{tabular}


Table 3-5: Bike LOS assessment chart [Source: (City of Ottawa, 2015)]

\begin{tabular}{|c|c|c|}
\hline \multirow{3}{*}{\multicolumn{2}{|c|}{$\begin{array}{l}\text { Type of Bikeway } \\
\text { Physically Separated Bikeway (cycle tracks, protected bike lanes and mult-use paths). Physical separafion refers to, but is not } \\
\text { limited to, curbs, raised medians, bollards and parking lanes (adjacent to the bike lane along the travelled way i.e. not curbside). } \\
\text { Bike Lanes Not Adiacent Parkina Lane - Select Worst Scorina Criteria }\end{array}$}} & LOS \\
\hline & & A \\
\hline & & Bike Lanes Not Adjacent Parking Lane - Select Worst Scoring Criteria \\
\hline \multirow{4}{*}{ No. of Travel Lanes } & 1 travel lane in each direction & A \\
\hline & 2 travel lanes in each direction separated by a raised median & B \\
\hline & 2 travel lanes in each direction without a separating median & $\mathrm{C}$ \\
\hline & More than 2 travel lanes in each direction & D \\
\hline \multirow{3}{*}{ Bike Lane Width } & $\geq 1.8 \mathrm{~m}$ wide bike lane (includes marked buffer and paved gutter width) & A \\
\hline & $\geq 1.5 \mathrm{~m}$ to $<1.8 \mathrm{~m}$ wide bike lane (includes marked buffer and paved gutter width) & $\mathrm{B}$ \\
\hline & $\geq 1.2 \mathrm{~m}$ to $<1.5 \mathrm{~m}$ wide bike lane (includes marked buffer and paved gutter width) & $\mathrm{C}$ \\
\hline \multirow{3}{*}{ Operating Speed } & $\leq 50 \mathrm{~km} / \mathrm{h}$ operafing speed & A \\
\hline & $60 \mathrm{~km} / \mathrm{h}$ operafing speed & $\mathrm{C}$ \\
\hline & $\geq 70 \mathrm{~km} / \mathrm{h}$ operating speed & $E$ \\
\hline \multirow{2}{*}{\begin{tabular}{|l|} 
Bike lane blockage \\
(commercial areas)
\end{tabular}} & Rare & $\mathrm{A}$ \\
\hline & Frequent & $\mathrm{C}$ \\
\hline \multicolumn{3}{|c|}{ Bike Lanes Adjacent to curbside Parking Lane - Select Worst Scoring Criteria } \\
\hline \multirow{2}{*}{ No. of Travel Lanes } & 1 travel lane in each direction & A \\
\hline & 2 or more travel lanes in each direction & $\mathrm{C}$ \\
\hline \multirow{3}{*}{ Bike Lane and Parking Lane Width } & $4.5 \mathrm{~m}$ wide bike lane plus parking lane (includes marked buffer and paved gutter width) & A \\
\hline & $4.25 \mathrm{~m}$ wide bike lane plus parking lane (includes marked buffer and paved gutter width) & $\mathrm{B}$ \\
\hline & $\leq 4.0 \mathrm{~m}$ wide bike lane plus parking lane (includes marked buffer and paved gutter width) & C \\
\hline \multirow{4}{*}{ Operafing Speed } & $\leq 40 \mathrm{~km} / \mathrm{h}$ operating speed & A \\
\hline & $50 \mathrm{~km} / \mathrm{h}$ operafing speed & $\mathrm{B}$ \\
\hline & $60 \mathrm{~km} / \mathrm{h}$ operating speed & $\bar{D}$ \\
\hline & $\geq 70 \mathrm{~km} / \mathrm{h}$ operating speed & $\mathrm{F}$ \\
\hline \multirow{2}{*}{\begin{tabular}{|l} 
Bike lane blockage \\
(commercial areas)
\end{tabular}} & Rare & $\mathrm{A}$ \\
\hline & Frequent & $\mathrm{C}$ \\
\hline \multicolumn{3}{|l|}{ Mixed Traffic } \\
\hline \multirow{8}{*}{$\begin{array}{l}\text { No. of Travel Lanes and Operafing } \\
\text { Speed }\end{array}$} & 2 travel lanes; $\leq 40 \mathrm{~km} / \mathrm{h}$; no marked centerline or classified as residenfal & A \\
\hline & 2 to 3 travel lanes; $\leq 40 \mathrm{~km} / \mathrm{h}$ & $\mathrm{B}$ \\
\hline & 2 travel lanes; $50 \mathrm{~km} / \mathrm{h}$; no marked centerline or classified as residential & $\mathrm{B}$ \\
\hline & 2 to 3 travel lanes; $50 \mathrm{~km} / \mathrm{h}$ & D \\
\hline & 4 to 5 travel lanes; $\leq 40 \mathrm{~km} / \mathrm{h}$ & $\mathrm{D}$ \\
\hline & 4 to 5 travel lanes; $\geq 50 \mathrm{~km} / \mathrm{h}$ & $\mathrm{E}$ \\
\hline & 6 or more travel lanes; $\leq 40 \mathrm{~km} / \mathrm{h}$ & $E$ \\
\hline & $\geq 60 \mathrm{~km} / \mathrm{h}$ & $\mathrm{F}$ \\
\hline \multicolumn{3}{|c|}{ Unsignalized Crossing along Route: no median refuge } \\
\hline \multirow{10}{*}{$\begin{array}{l}\text { No. of Travel Lanes on Side Street } \\
\text { and Operating Speed }\end{array}$} & 3 or less lanes being crossed; $\leq 40 \mathrm{~km} / \mathrm{h}$ & A \\
\hline & 4 to 5 lanes being crossed; $\leq 40 \mathrm{~km} / \mathrm{h}$ & $\mathrm{B}$ \\
\hline & 3 or less lanes being crossed; $50 \mathrm{~km} / \mathrm{h}$ & $\mathrm{B}$ \\
\hline & 4 to 5 lanes being crossed; $50 \mathrm{~km} / \mathrm{h}$ & $\mathrm{C}$ \\
\hline & 3 or less lanes being crossed; $60 \mathrm{~km} / \mathrm{h}$ & $\mathrm{C}$ \\
\hline & 4 to 5 lanes being crossed; $60 \mathrm{~km} / \mathrm{h}$ & $\mathrm{D}$ \\
\hline & 6 or more lanes being crossed; $\leq 40 \mathrm{~km} / \mathrm{h}$ & $E$ \\
\hline & 3 or less lanes being crossed; $\geq 65 \mathrm{~km} / \mathrm{h}$ & $E$ \\
\hline & 6 or more lanes being crossed; $\geq 50 \mathrm{~km} / \mathrm{h}$ & $\mathrm{F}$ \\
\hline & 4 to 5 lanes being crossed; $\geq 65 \mathrm{~km} / \mathrm{h}$ & $\mathrm{F}$ \\
\hline \multicolumn{3}{|c|}{ Unsignalized Crossing along Route: with median refuge ( $>1.8 \mathrm{~m}$ wide) } \\
\hline \multirow{11}{*}{$\begin{array}{l}\text { No. of Travel Lanes on Side Street } \\
\text { and Operating Speed }\end{array}$} & 5 or less lanes being crossed; $\leq 40 \mathrm{~km} / \mathrm{h}$ & A \\
\hline & 3 or less lanes being crossed; $50 \mathrm{~km} / \mathrm{h}$ & A \\
\hline & 6 or more lanes being crossed; $\leq 40 \mathrm{~km} / \mathrm{h}$ & B \\
\hline & 4 to 5 lanes being crossed; $50 \mathrm{~km} / \mathrm{h}$ & $\mathrm{B}$ \\
\hline & 3 or less lanes being crossed; $60 \mathrm{~km} / \mathrm{h}$ & $\mathrm{B}$ \\
\hline & 6 or more lanes being crossed; $50 \mathrm{~km} / \mathrm{h}$ & $\mathrm{C}$ \\
\hline & 4 to 5 lanes being crossed; $60 \mathrm{~km} / \mathrm{h}$ & $\mathrm{C}$ \\
\hline & 3 or less lanes being crossed; $\geq 65 \mathrm{~km} / \mathrm{h}$ & $\mathrm{D}$ \\
\hline & 6 or more lanes being crossed; $60 \mathrm{~km} / \mathrm{h}$ & $\mathrm{E}$ \\
\hline & 4 to 5 lanes being crossed; $\geq 65 \mathrm{~km} / \mathrm{h}$ & $\mathrm{E}$ \\
\hline & 6 or more lanes being crossed; $\geq 65 \mathrm{~km} / \mathrm{h}$ & $\mathrm{F}$ \\
\hline
\end{tabular}


Table 3-6: Desired LOS for specific policy area context [ Source: (City of Ottawa, 2015) ]

\begin{tabular}{|c|c|c|c|c|c|c|}
\hline \multirow[b]{2}{*}{ OP Designation / Policy Area } & \multirow[b]{2}{*}{ Road Class } & \multirow[b]{2}{*}{ PLOS } & \multicolumn{4}{|c|}{ Bicycle-BLOS } \\
\hline & & & $\begin{array}{c}\text { Cross-town } \\
\text { Bikeway }\end{array}$ & Spine Route & Local Route & Elsewhere \\
\hline \multicolumn{7}{|l|}{ 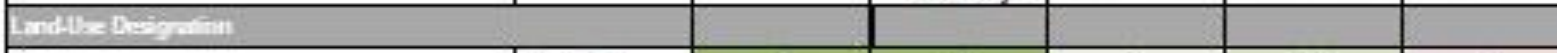 } \\
\hline \multirow{3}{*}{ Central Area } & Arterial & A & A & c & B & D \\
\hline & Collector & A & A & $\mathrm{B}$ & $\mathrm{B}$ & D \\
\hline & Local & A & A & B & B & D \\
\hline \multirow{3}{*}{ Developing Community } & Arterial & c & $\mathrm{B}$ & $\mathrm{c}$ & $\mathrm{B}$ & D \\
\hline & Collectbr & $\mathrm{C}$ & $\mathrm{B}$ & $\mathrm{C}$ & $\mathrm{B}$ & $\mathrm{D}$ \\
\hline & Local & C & B & C & B & $\mathrm{D}$ \\
\hline \multirow{3}{*}{ Employment Area } & Anterial & $\mathrm{C}$ & $\mathrm{B}$ & $\mathrm{C}$ & c & $E$ \\
\hline & Collector & $\mathrm{C}$ & $\mathrm{B}$ & E & c & $E$ \\
\hline & Local & $\mathrm{c}$ & $\mathrm{B}$ & D & $\mathrm{c}$ & No target \\
\hline \multirow{3}{*}{ Entreprise Area } & Arterial & $\mathrm{c}$ & $\mathrm{B}$ & $\mathrm{C}$ & $\mathrm{B}$ & D \\
\hline & Collectbr & $\mathrm{C}$ & $\mathrm{B}$ & $\mathrm{C}$ & $\mathrm{B}$ & $\mathrm{D}$ \\
\hline & Local & C & $B$ & C & B & No target \\
\hline \multirow{3}{*}{ General Rural Area } & Arterial & No target & NA & D & D & No target \\
\hline & Collectbr & No target & NAA & $\mathrm{D}$ & D & No target \\
\hline & Local & No target & N:A & $\mathrm{D}$ & D & No target \\
\hline \multirow{3}{*}{ General Urban Area } & Arterial & $\mathrm{C}$ & $\mathrm{B}$ & C & $B$ & D \\
\hline & Collectbr & $\mathrm{c}$ & $\mathrm{B}$ & $\mathrm{c}$ & $B$ & $D$ \\
\hline & \begin{tabular}{|l|} 
Local \\
\end{tabular} & $\mathrm{C}$ & $\mathrm{B}$ & $\mathrm{C}$ & $\mathrm{B}$ & $\mathrm{D}$ \\
\hline \multirow{3}{*}{ Mixed Use Centre } & Anterial & c & A & c & B & $D$ \\
\hline & Collector & C & A & $B$ & $B$ & $D$ \\
\hline & Local & $\mathrm{C}$ & A & $B$ & $B$ & D \\
\hline \multirow{3}{*}{ Village } & Anterial & $\mathrm{c}$ & $B$ & $\mathrm{C}$ & $\mathrm{B}$ & $D$ \\
\hline & Collector & c & B & c & $\mathrm{B}$ & D \\
\hline & Local & $\mathrm{c}$ & B & & B & $\mathrm{D}$ \\
\hline \multirow{2}{*}{ Traditional Main Street } & Arterial & $B$ & A & c & c & $\mathrm{D}$ \\
\hline & Collector & $B$ & A & C & c & D \\
\hline Arterial Main Street & Arterial & C & B & c & D & D \\
\hline \multirow{3}{*}{ All Other Designations } & Atterial & $\mathrm{D}$ & $\mathrm{B}$ & c & c & $\mathrm{D}$ \\
\hline & Collector & $\mathrm{D}$ & $B$ & C & c & $\mathrm{D}$ \\
\hline & Local & $\mathrm{D}$ & $\mathrm{B}$ & C & c & $D$ \\
\hline \multicolumn{7}{|l|}{ 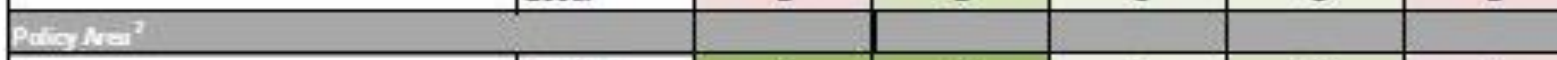 } \\
\hline \multirow{3}{*}{ Within $600 \mathrm{~m}$ of a rapid transit station } & Arterial & A & A & c & $\mathrm{B}$ & D \\
\hline & Collector & A & A & B & $\mathrm{B}$ & D \\
\hline & Local & A & A & $\mathrm{B}$ & $\mathrm{B}$ & D \\
\hline \multirow{3}{*}{ Within $300 \mathrm{~m}$ of a school } & Anterial & $\mathrm{A}$ & $A$ & c & $B$ & D \\
\hline & Collector & $\mathrm{A}$ & A & $B$ & $B$ & $\mathrm{D}$ \\
\hline & Local & A & A & B & B & D \\
\hline
\end{tabular}




\subsection{Pedestrian and Bicycle LOS Calculator}

Bicycle Level of Service (BLOS) is a nationally-used measure of on-road bicyclist comfort level as a function of a roadway's geometry and traffic conditions, developed by Sprinkle Consulting based on the Highway Capacity Manual. Roadways with a better (lower) score are more attractive (and usually safer) for adult cyclists. This calculator is heavily used due to its simplicity of nature and user friendly if the required data is available.

Table 3-7: Bicycle and Pedestrian LOS parameters and description [Source: (League of Illinois Bicyclists, 2017)]

\section{Bicycle and Pedestrian Level of Service}

\begin{tabular}{|c|c|}
\hline Parameters & Description \\
\hline Through lanes per direction: & Do not include medians, turn lanes, or continuous-left-turn lanes. \\
\hline $\begin{array}{l}\text { Width of outside travel lane, to } \\
\text { outside stripe (in feet): }\end{array}$ & $\begin{array}{l}\text { Width of right-most travel lane, excluding striped paved shoulders, } \\
\text { bike lanes, and marked parking stalls. }\end{array}$ \\
\hline $\begin{array}{l}\text { Paved shoulder, bike lane, OR } \\
\text { marked parking area, outside lane } \\
\text { stripe to pavement edge (in feet): }\end{array}$ & $\begin{array}{l}\text { Besides a paved shoulder or a bike lane, this width may also be } \\
\text { marked (striped or hashed) parking stalls. For diagonal parking, use } \\
\text { the perpendicular distance from the end of the parking stripes to the } \\
\text { pavement edge. This calculator does not work when there are BOTH } \\
\text { bike lanes and parking stalls - please see the reference for this case. }\end{array}$ \\
\hline $\begin{array}{l}\text { Bi-directional Traffic Volume (in } \\
\text { ADT): }\end{array}$ & $\begin{array}{l}\text { Daily average. Assumed Directional factor }(0.565) \text { and Peak Hour } \\
\text { Factor }(0.091) \text { values are used in a conversion to peak } 15 \text {-minute } \\
\text { volume. }\end{array}$ \\
\hline Percentage of heavy vehicles: & As defined in the Highway Capacity Manual. \\
\hline $\begin{array}{l}\text { Percentage of road segment with } \\
\text { occupied on-street parking: }\end{array}$ & $\begin{array}{l}\text { Exclude driveways. Either one side or an average of both sides may be } \\
\text { considered at a time. }\end{array}$ \\
\hline $\begin{array}{l}\text { Percentage of segment with } \\
\text { sidewalks: }\end{array}$ & Again, either one side or an average of both sides may be considered. \\
\hline Sidewalk width (in feet): & If a side path bike trail exists instead of a sidewalk, use its width. \\
\hline $\begin{array}{l}\text { Sidewalk buffer/parkway width (in } \\
\text { feet): }\end{array}$ & $\begin{array}{l}\text { Average distance from pavement edge to sidewalk edge. Include any } \\
\text { gutter pan width. }\end{array}$ \\
\hline $\begin{array}{l}\text { Buffer/parkway average tree } \\
\text { spacing (in feet): }\end{array}$ & Between tree trunks. \\
\hline
\end{tabular}




\section{Model parameter}

The BLOS model was developed using roads with the following parameter ranges (League of Illinois Bicyclists, 2017):

- Through lanes per direction - 1 to 3 (2 to 6 lane roads)

- Width of outside travel lane, to outside stripe - 10 to 16 feet

- Paved shoulder or bike lane, outside lane stripe to pavement edge - 0 to 6 feet (no rumble strips)

- Bi-directional traffic volume - 550 to 36,000 ADT (Average Daily Traffic)

- Posted speed limit - 25 to $50 \mathrm{mph}$

- Percentage of heavy vehicles - 0 to $2 \%$

- FHWA's pavement condition rating - 5 (very good) to 2 (poor)

- A wide range of development types and parking conditions

The parameter ranges used in developing the PLOS model includes(League of Illinois Bicyclists, 2017):

- Through lanes per direction - 1 to 2 (2 to 4 lane roads)

- Bi-directional traffic volume - 200 to 18,000 ADT (Average Daily Traffic)

- Traffic speeds - 15 to $75 \mathrm{mph}$

- Percentage of heavy vehicles - 0 to $3 \%$

- Ranges of development types, road widths, paved shoulders and bike lanes, on-street parking percentages, sidewalk widths and sidewalk buffer widths and types

Table 3-8: The BLOS/PLOS calculator data input form

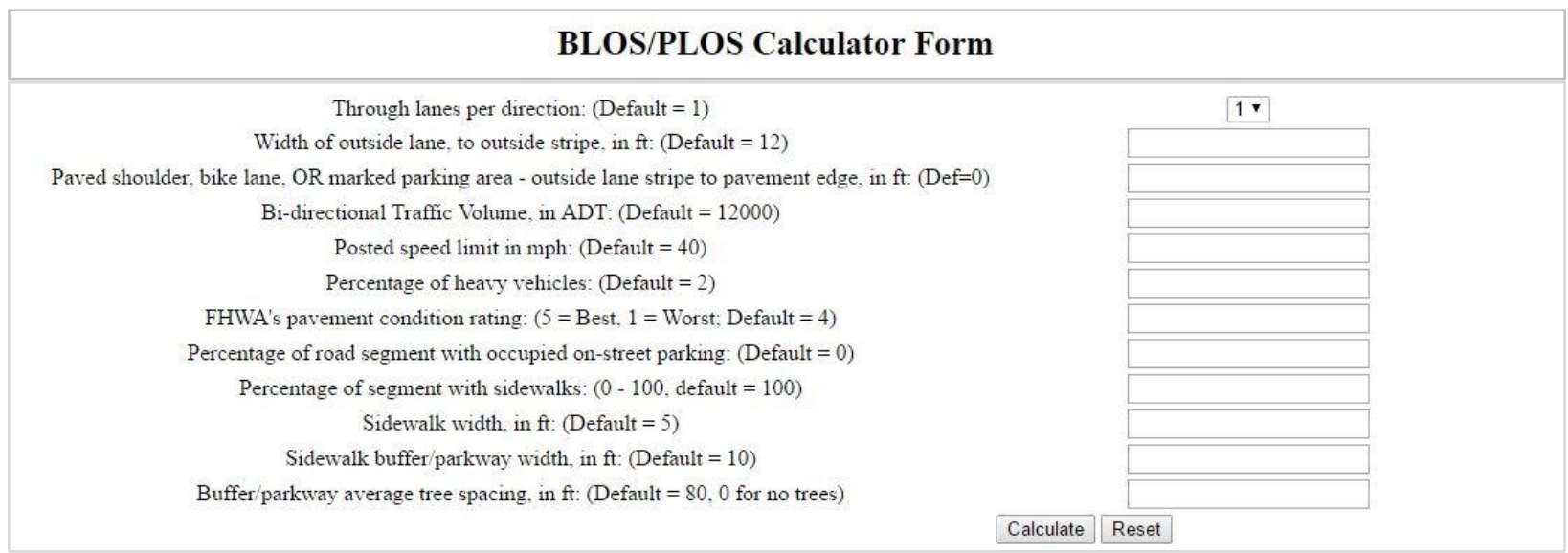




\section{METHODOLOGY AND DATA COLLECTION}

\subsection{Methodology}

Better data and quantitative modeling of the benefits of active transportation facilities become centre point of city building while policy makers seek to expand investments in network-wide, safer and higher quality infrastructures to realize the true costs and benefits of these decisions. To ensure that future projects, funding allocations and policy decisions achieve goals related to mode shift, reduced vehicle kilometer traveled (VKT), cost effectiveness, greenhouse gas reductions and improved public health, it is vital that the scale of current latent and future demand are modeled accurately to capture the benefits of active transportation investments.

The proposed methodology intends to assist practitioners, planners and engineers for evaluating the development of the infrastructure facility based on actual and latent demand through quantitative analysis and techniques. To evaluate active transportation facilities, performance measures auch as quality of service, proximity analysis for transit station and school area, and connectivity measures for active modes were estimated for case study area. Quality and level of service methodologies were adopted from Ottawa Multimodal Level of Service Guidelines, and pedestrian and Bicycle Level of Service from Highway Capacity Manual (2010). Data was collected based on the model parameters and the study area context. Types of data used in this study includes existing mode share; traffic count data at signalized intersection including walking and cycling volumes; existing and latent network demand, and information on active transportation infrastructures. North York center area in the city of Toronto was selected as a case study to investigate and apply the proposed methodology. The latent active transportation demand has been estimated using short trips recorded in the area-wide transportation demand database (TTS 2011) and existing travel pattern data for modes of transportation. Based on the estimated demand and evaluation measures, infrastructure improvements for walking and cycling have been considered using recent local and international design guidelines. Finally, performance evaluation measures were applied to the improved infrastructures to see the desired quality, safety and connectivity of the existing streets. 


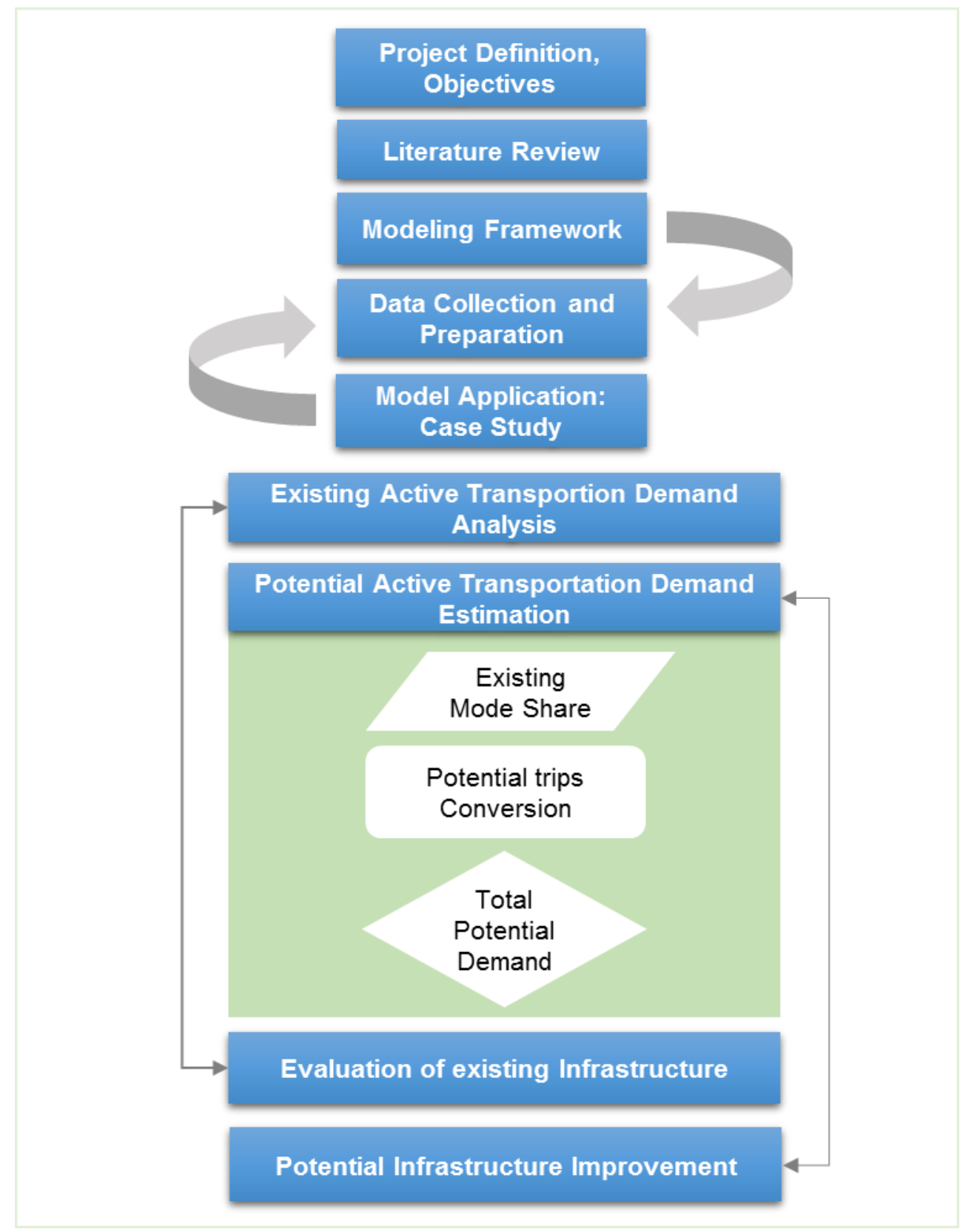

Figure 4-1: Methodology for active transportation mobility demand modeling and infrastructure assessment 


\subsection{Data Collection and Preparation}

\subsubsection{Mode share}

Transportation Tomorrow Survey (TTS) collects information on demographics (age, gender), travel choices and preferences of people who live in Greater Toronto and Hamilton Area (GTHA). These data are collected in every five years. The most recent information is from 2011 TTS data. These data helps us to determine long range planning; serves the major source as a travel demand forecasting tools and to planning for the transportation facilities needed to improve. In this project, the individual trip data was used based on the choice of the transport mode. A "trip" means any one-way journey from one place to another by foot, bicycle or motorized vehicle. For walking, the interviewer collected only information on trips to and from work or school. Therefore, a large amount to leisure, shopping or other walking trips especially, during the afternoon or evening were not considered. Distance covered by each trip was collected, where trip distance means the straight-line distance or crow flying distance. Since walking and cycling trips mostly depends upon the trip distance, this data was very useful for this project.

\subsubsection{Traffic Movement Count (TMC)}

In this study, the city of Toronto traffic movement data that collects the traffic volume including walking and cycling count at the intersections were used. For instance, walking and cycling data are counted on the North, South, East and West crosswalks and directions. The peak hour walking and cycling demand at the intersection is found from this data for both morning and evening peak hours. Traffic movement data for all the signalized intersections in the study area is attached here in the Appendix A.

\subsubsection{Traffic Signal Operation}

To understand the pedestrian network performance, it is necessary to get the data for the signalized operation. Data was collected at each signalized intersection in the study area in order to know the pedestrian delay and overall cycle time. 


\subsubsection{Walking and Cycling Infrastructure}

Existing walking network facilities including walking connection between the streets, sidewalk width, boulevard width is collected from the city wide open data source (City of Toronto Open Data Portal, 2017) and most recent Google image. Cycling infrastructure data including, existing and planned cycling network facilities, type of facilities is collected from the city of Toronto open data catalogue and websites (City of Toronto Open Data Portal, 2017).

\subsubsection{Roadway Geometric design}

Road geometric data includes existing right-of-way width of the different streets, lane width, parking lane width, median width, shoulder/boulevard width. These data are measured by using city wide transportation network map. (http://map.toronto.ca/maps/map.jsp?app=ZBL CONSULT)

\subsubsection{Posted Speed}

Posted speed for vehicles is displayed in different streets and even sometimes it varies in different segments of the streets. Posted speed data was collected from different segments of the streets by checking the data through Google street view and a site visit. Generally, the operating speed is $85^{\text {th }}$ percentile speed from all vehicles running in the streets which is roughly 10-15\% higher than the posted speed depending on the time of the day or street types(Fitzpatrick et al., 2003). 


\section{CASE STUDY: MODEL APPLICATION \&RESULTS}

\subsection{Study Area in Multimodal Transportation Context}

The study area is in North York District, City of Toronto which is just above the Higway 401 and bounded by the Finch Avenue at the north, Sheppard Avenue at the south, Senlac Avenue at west and Willowdale Avenue at the east (Figure 5-1). The study mainly focuses on the North York Centre also known as Downtown North York. This area falls under the boundary of ward \# 23.

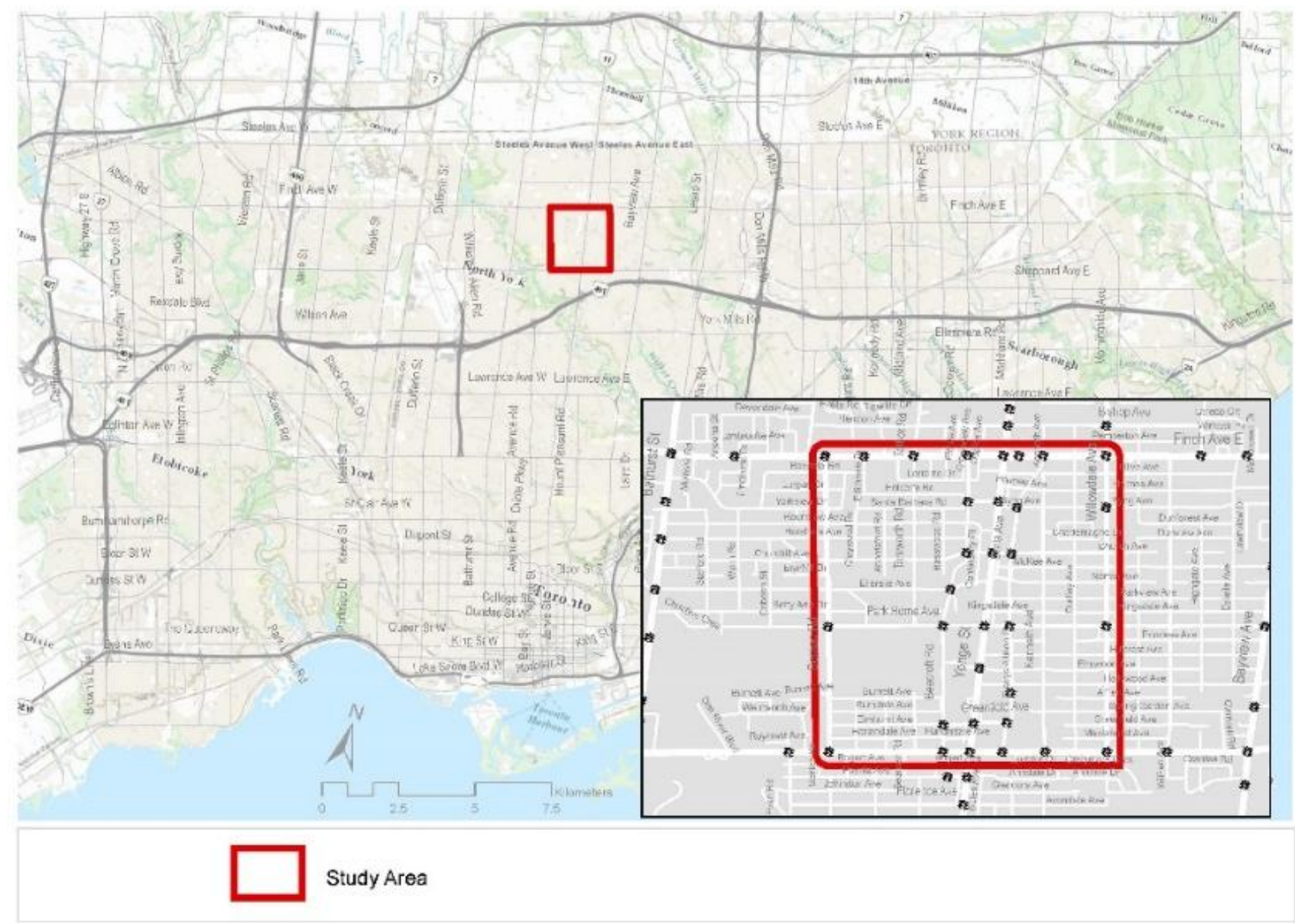

Figure 5-1: Study Area Map 


\subsubsection{Transportation Network and Demand}

The road network map showing existing functional classification of the streets is based on City of Toronto road classification system (City of Toronto, 2013). The collectors are not properly connected within the study area and the reason why arterials are having much pressure for the traffic movement in the study area (Figure 5-2). Existing intersection traffic demand shows that the Yonge street corridor has higher demand in compare to the other arterials nearby. Whereas the minor arterials parallel street like Senlac on the west and Willowdale on the East of Yonge street are not carrying much traffic due to the discontinuity.

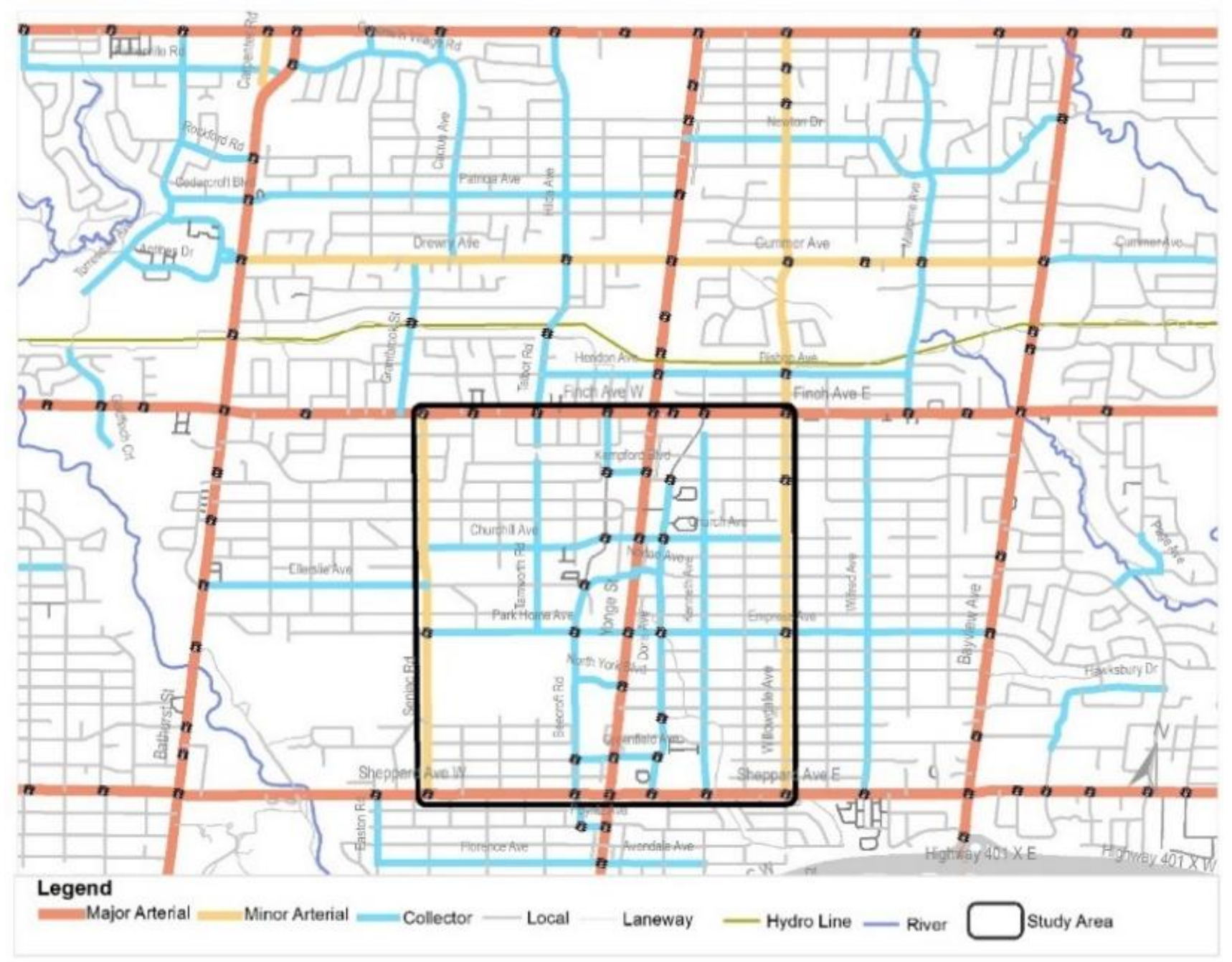

Figure 5-2: Road Network with Functional Classification. 


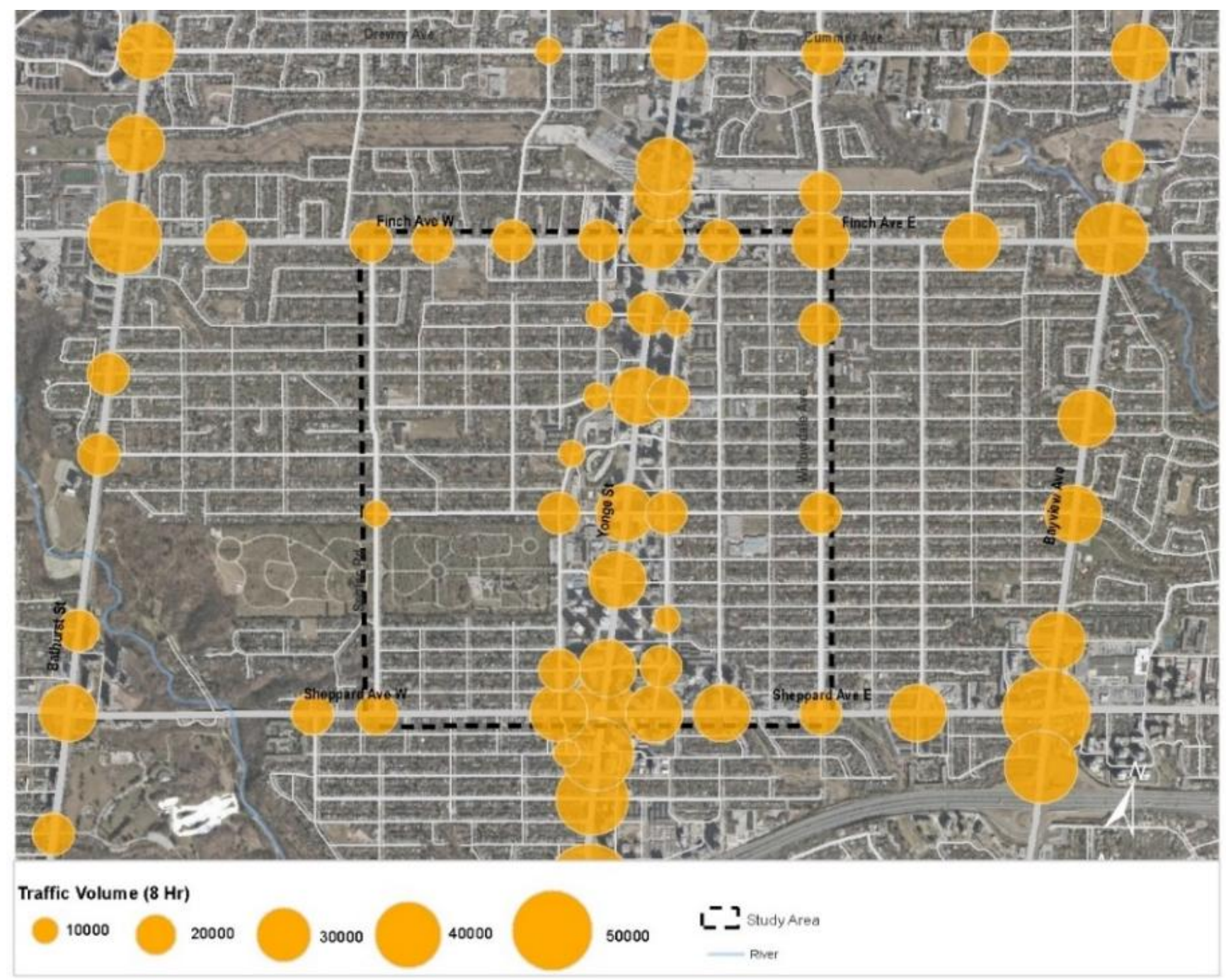

Figure 5-3: Existing Traffic Demand in the intersections.

\subsubsection{Cycling Network and Demand}

Cycling demand was found to be higher on the North-South parallel collector road, Beecroft and Doris, compared to the other streets, as it is illustrated in Figure 5-4. Currently, there is no cycling infrastructure exist despite the high cycling demand and transit corridor. However, City of Toronto has already planned for the new cycling network connecting East-West along Churchill/Church Ave and NorthSouth along Yonge Street, Senlac and Willowdale Ave (City of Toronto, 2016). 


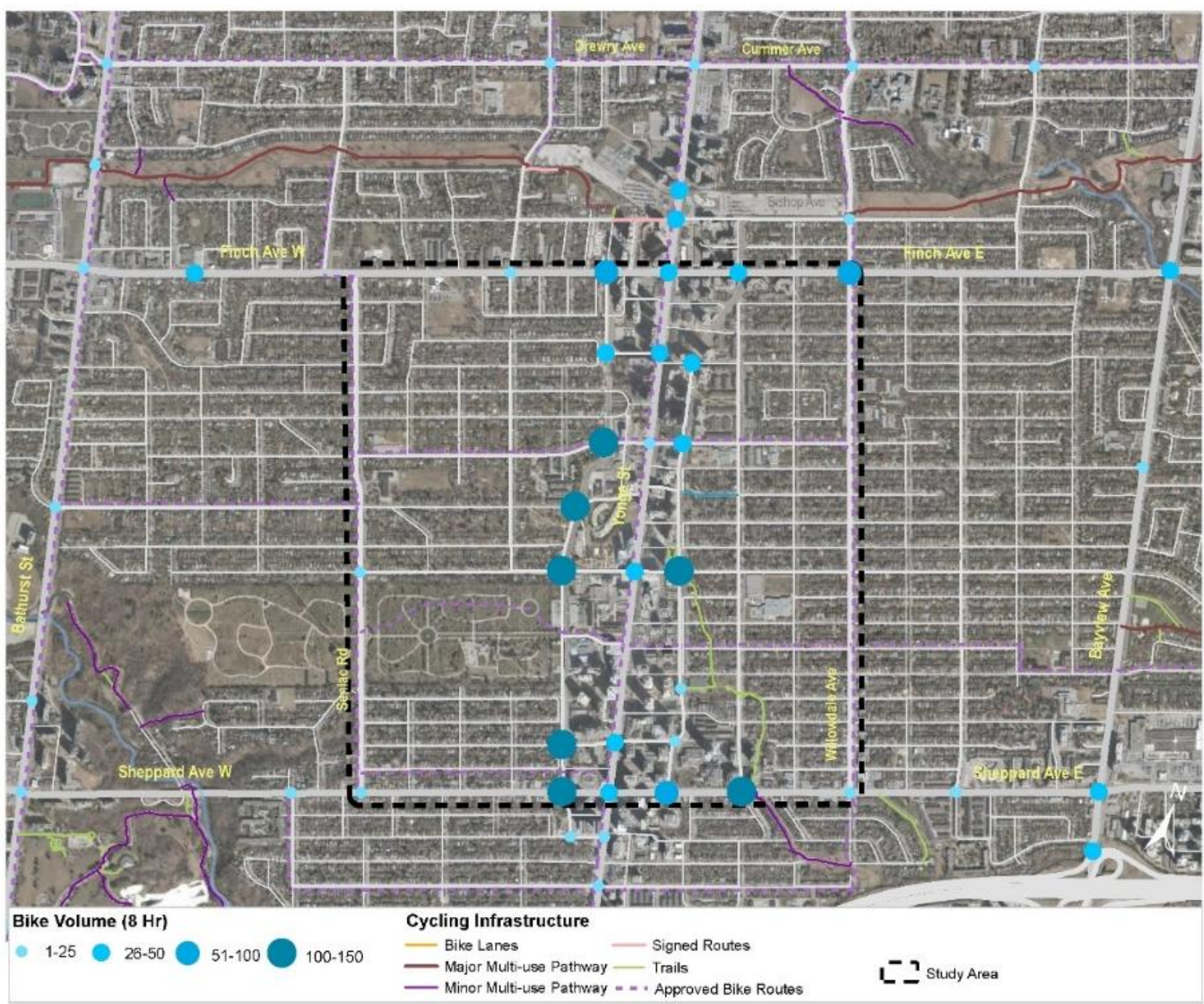

Figure 5-4: Cycling Infrastructure and Demand

\subsubsection{Walking Network and Demand}

Pedestrian demand was also found quite high on the Yonge street corridor. There are numbers of factors depends on this very high demand on Yonge street. The high population and job density, mixed land-use, employment zone and higher order transit corridor are some of the major factors for this high pedestrian along this corridor. However, it is visible by the map that the walking infrastructure such as, sidewalks are not well connected and somewhere it is missing in the neighborhood (Figure 5-5). 


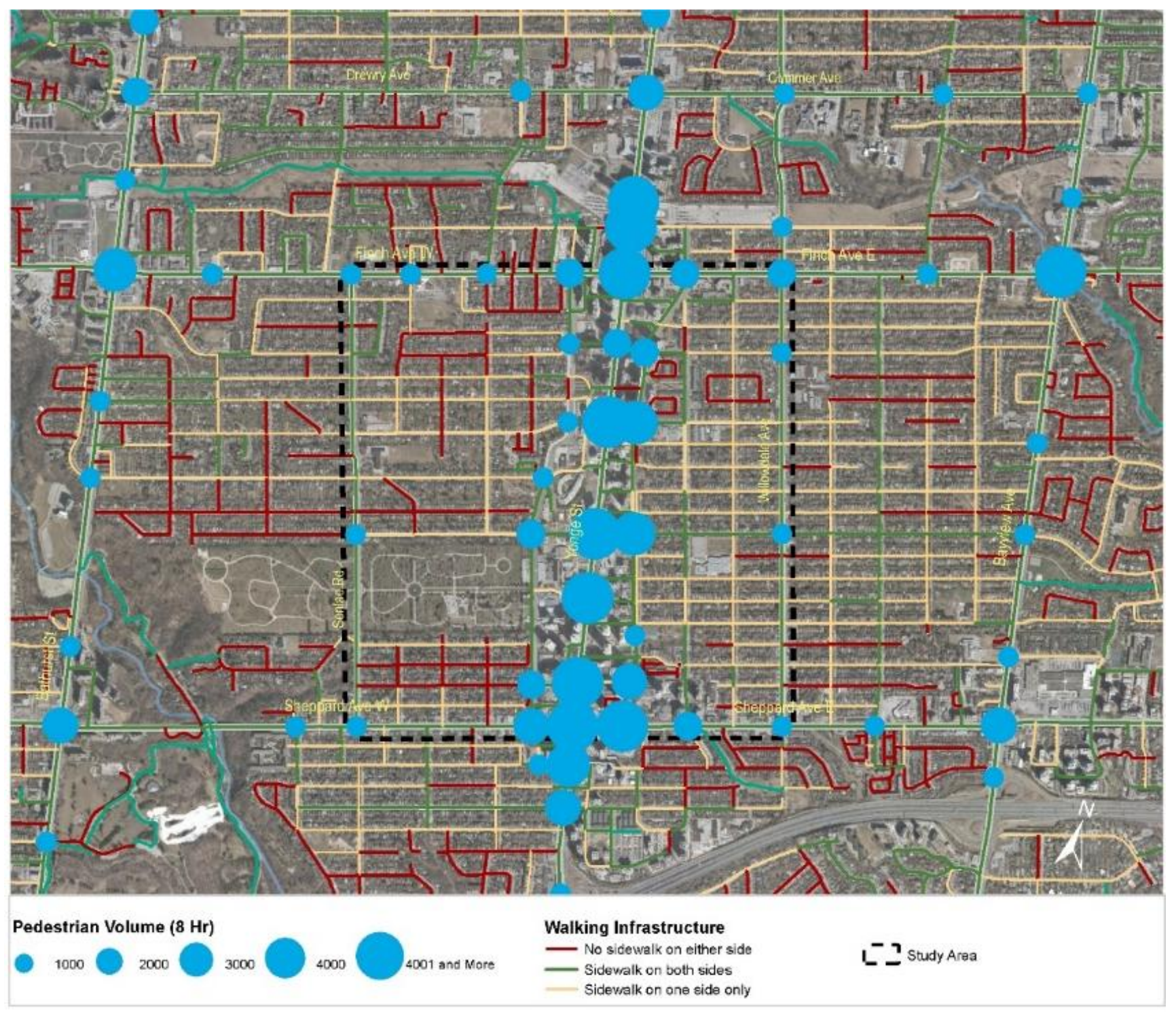

Figure 5-5: Walking network and demand

\subsubsection{Study Area: walking and cycling problems and prospects}

Site visit was carried out to get the current conditions of walking and cycling in the study area. The photos along with some observations or comments are addressing the local active transportation condition, are displayed by the Figure 5-6 to Figure 5-9.

Cycling Conditions:

- Existing potential for cycling demand is represented by the high volume of bikes in the bike racks 
- Only a few bike racks were found along the Yonge Street near to the Mel Lasman Square which seems quite insufficient. Even the bike racks were placed in such a manner that blocks the sidewalk.

- Only some strong cyclists are seen due to lack of cycling facilities in the area and high speed vehicles.

- Most of the cyclists look like student or young age.

- The overall condition was found very unsuitable for cyclist.

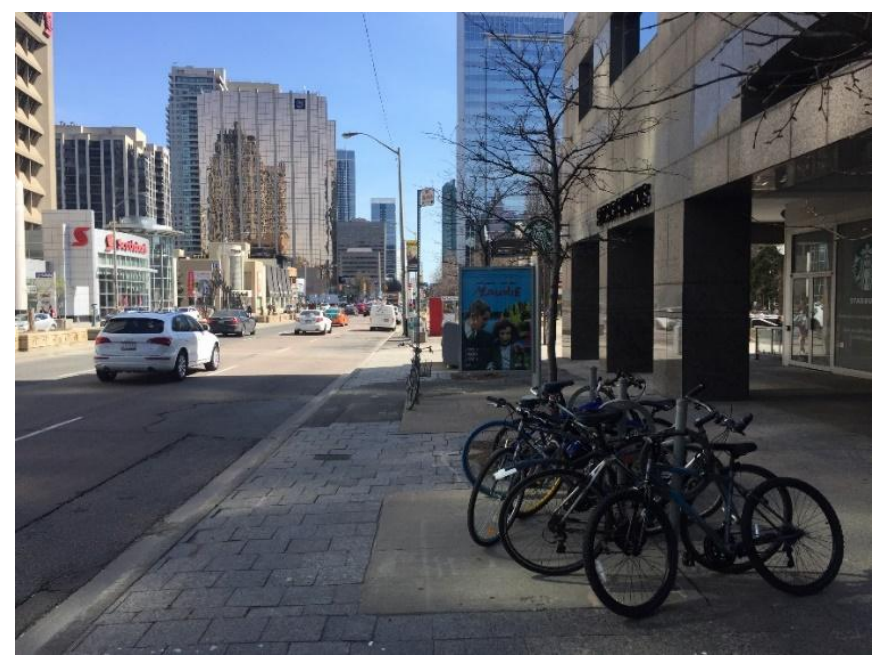

Figure 5-6: Bike facilities in the North York Centre

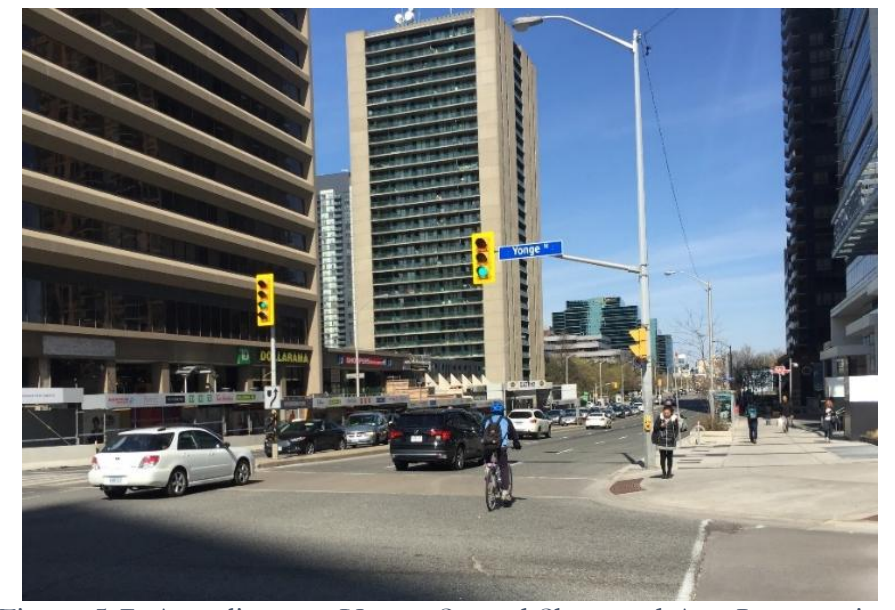

Figure 5-7: A cyclist near Yonge St. and Sheppard Ave Intersection 


\section{Pedestrian Conditions}

- High Pedestrian volume was observed during the evening, especially people at all ages commuting from the work place.

- Most of pedestrians were observed near to the transit stations and bus stops

- Some of them were also going for shopping after the work.

- Lack of sidewalk clear zone was observed.

- Heavy construction was also hindering pedestrian movements.

- Lack of trees or buffer zone between vehicle travel lane and sidewalk were observed in East side of Yonge St. especially.

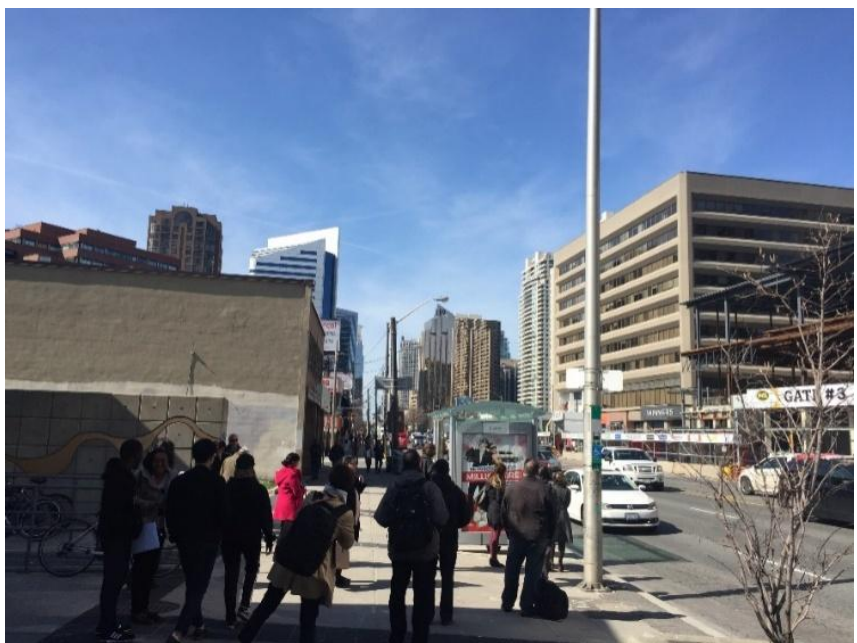

Figure 5-8: Pedestrian waiting for the bus at the sidewalk

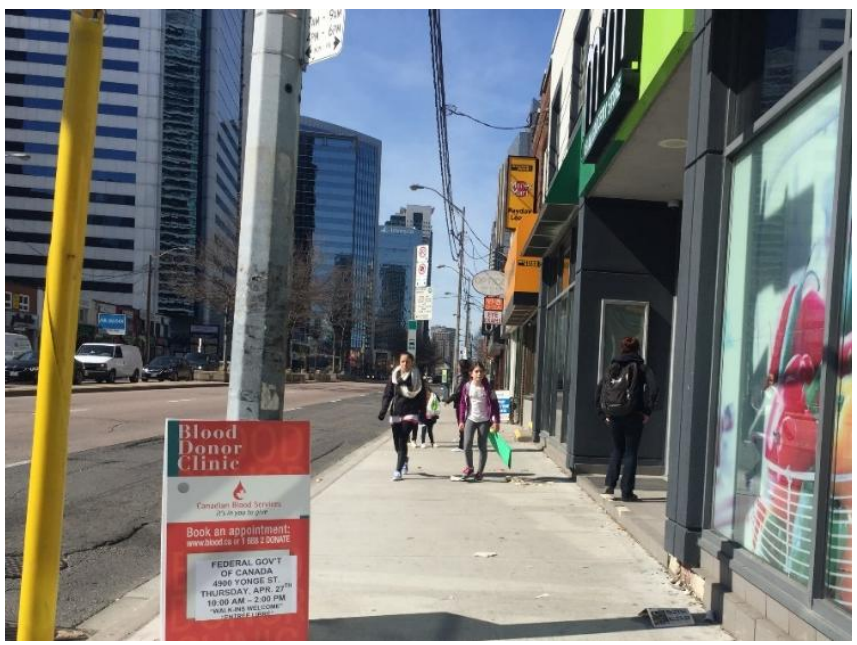

Figure 5-9: Insufficient Sidewalk Clear zone at Yonge St East side 


\subsection{Proximity to Rapid Transit Stations and Schools area}

The rapid transit stations and schools are considered as the high pedestrian and cycling trips generators. The catchment areas from rapid transit stations and schools are displayed by Figure 5-10 and Figure 5-11. It is shown that most of the streets/areas under the study area are in that catchment area which means this area should be highly prioritized and focused for active transportation. In addition, according to the multimodal transportation LOS guidelines from city of Ottawa, the level of service should be highest in those zones, $600 \mathrm{~m}$ buffer from the rapid transit and 300m from the school site locations(City of Ottawa, 2015).

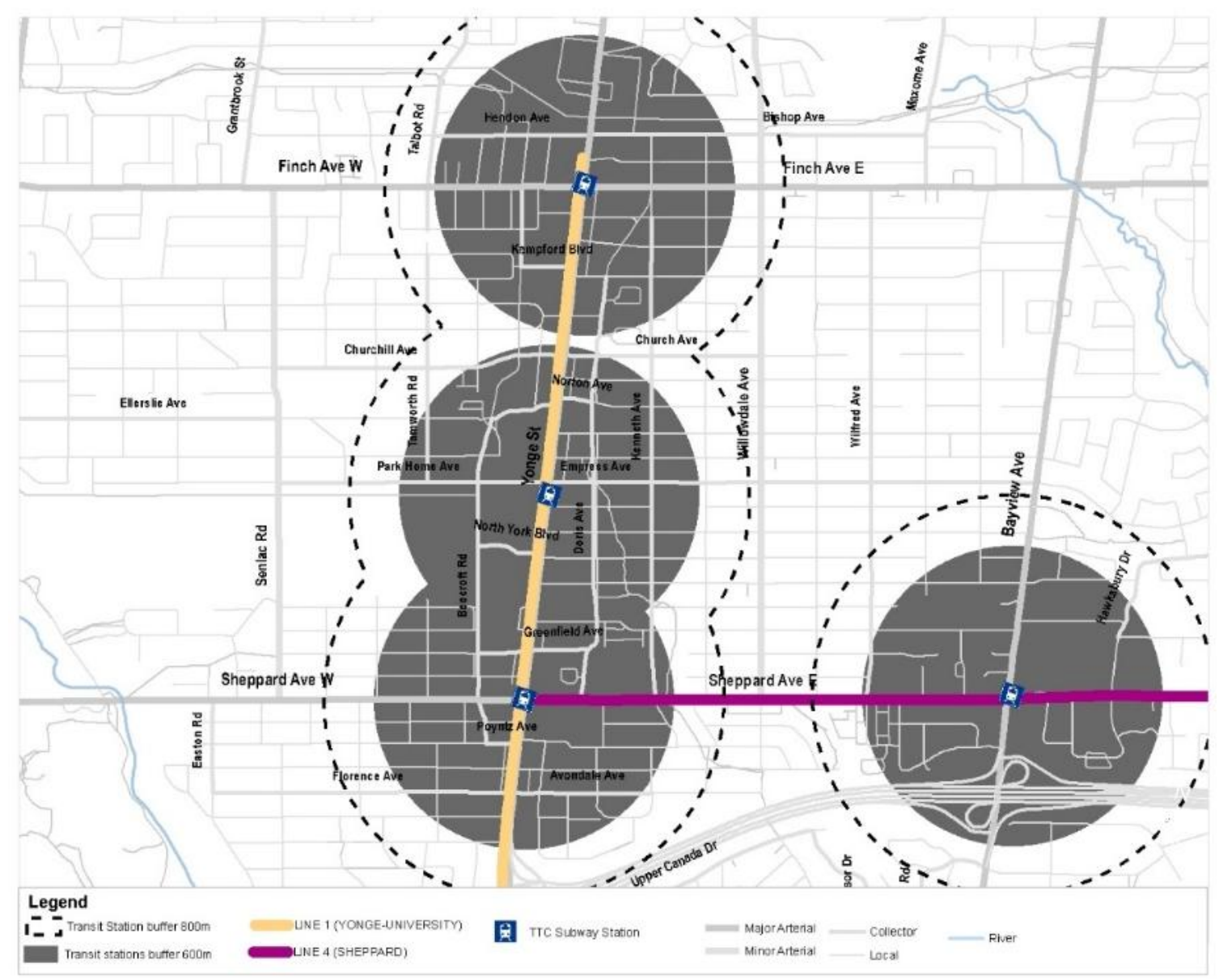

Figure 5-10: Rapid Transit Corridor and Station Catchment areas with 600m and 800m buffer 


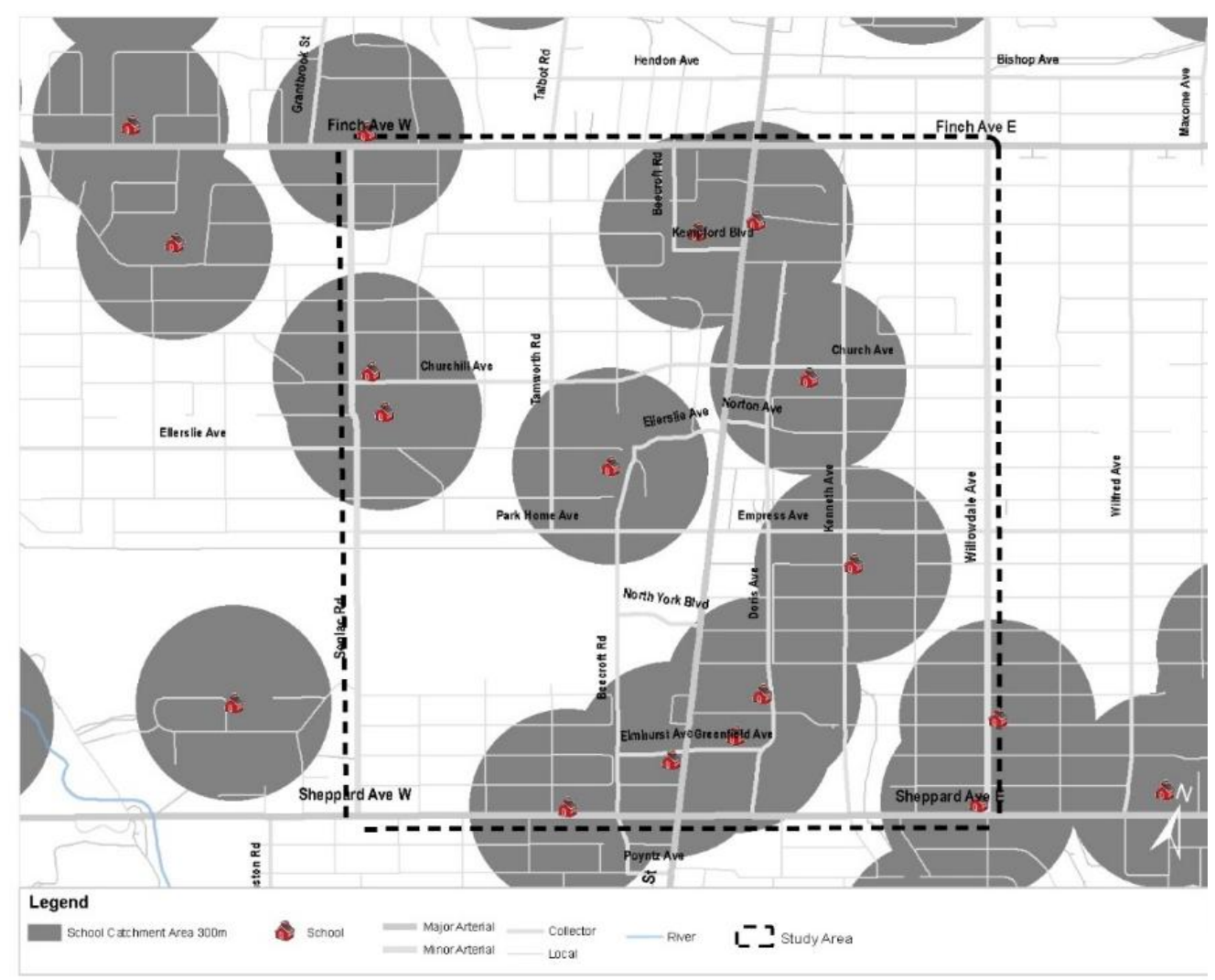

Figure 5-11: School zone catchment area with $300 \mathrm{~m}$ buffer

\subsection{Connectivity Index: Active Mode}

Street connectivity is one of the key components for the good neighborhood design as per advocates of new urbanist and in the concept of neo-traditional planning (Dill, 2004). The census tract was used to measure the Connectivity Index (CI). According to The City of Calgary Connectivity Handbook (2010), the total number of links and nodes for active transportation were calculated in each census zone and based on the range provided earlier in the methodology section. The table (Appendix B) shows whether the census tract connectivity index falls within the desirable zones or not. The result shows that most of the area is not in desirable zone for the active transportation connectivity criteria.

Figure 5-12 illustrates that only south-west side of Yonge Street was found well connected, where cycling and pedestrian routes exist. However, the area along the Yonge Street from Sheppard to Finch was mostly curvilinear, except only one zone where the North York center is located. These results also suggest that there is lack of active transportation facilities and links in this area. 
Street network that are more grid iron pattern are more preferred over the network that has more culde-sacs and long blocks, thus increases the walking or cycling distances between destinations. Even though the area has very high potential to be as the higher walking and cycling activity due to the land use type is mixed use and residential, also three subway stations already exists along the Yonge street corridor from Sheppard Avenue to Finch Avenue. Due to the lack of direct street connection, shown by Figure 5-12, the overall walking and cycling is discouraged despite the higher potential for active transportation. In order to provide a direct and shorter route for the pedestrian and bike we have to provide more connected streets and small blocks.

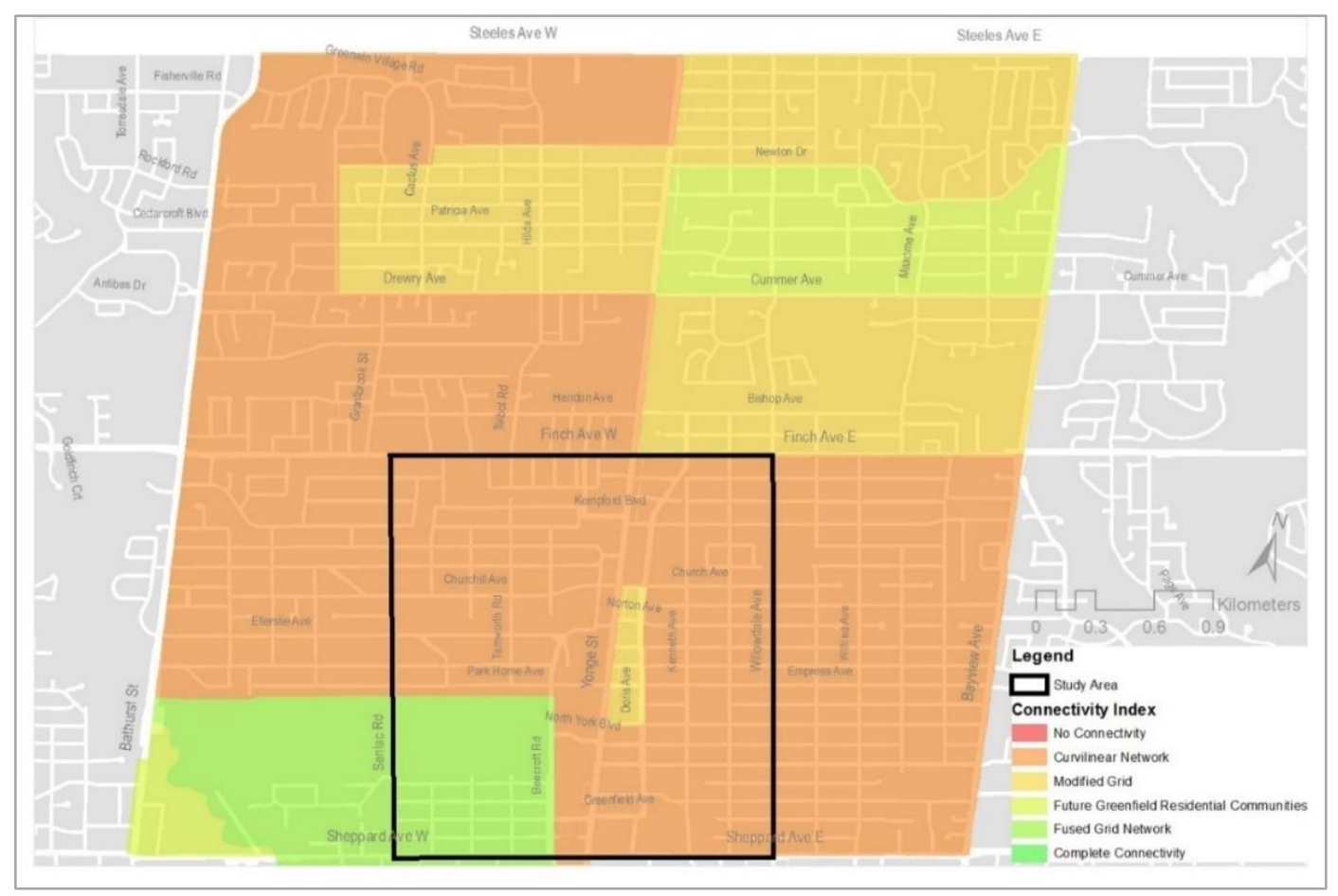

Figure 5-12: Active mode connectivity measure for census zones.

\subsection{Network Performance Analysis: Level of Service Methods}

\subsubsection{Pedestrian Network Level of Service}

A network quality analysis was done using the City of Ottawa Multimodal Level of Service (MMLOS) methodology on the major arterial streets and some collectors focusing on the North York center area. The overall results show that the performance along the major arterial streets is quite poor compared to that of the minor arterial and Collector Street. The map illustrates that Finch Avenue and Sheppard Ave are having LOS E, which means very low pedestrian comfortability. However, Yonge Street has LOS D 
due to lower speed limit (speed limit $50 \mathrm{~km} / \mathrm{hr}$.) and on-street parking facilities (some segments). The minor arterials are having LOS C, means moderately high comfortable along most of the streets except the Empress Avenue due to its not having the boulevard present.

On the other hand, the pedestrian crossings LOS were found worst in most of the arterial street crossings than that of minor arterial/collector. Pedestrian crosswalk in the intersections on the Arterial corridor such as; Yonge Street, Finch Avenue and Sheppard Avenue are all LOS F, that means the lowest comfortable for pedestrian, due to higher number of lanes to cross and the operating speed of the arterial corridor is higher than the minor arterial/collector (Figure 5-13).

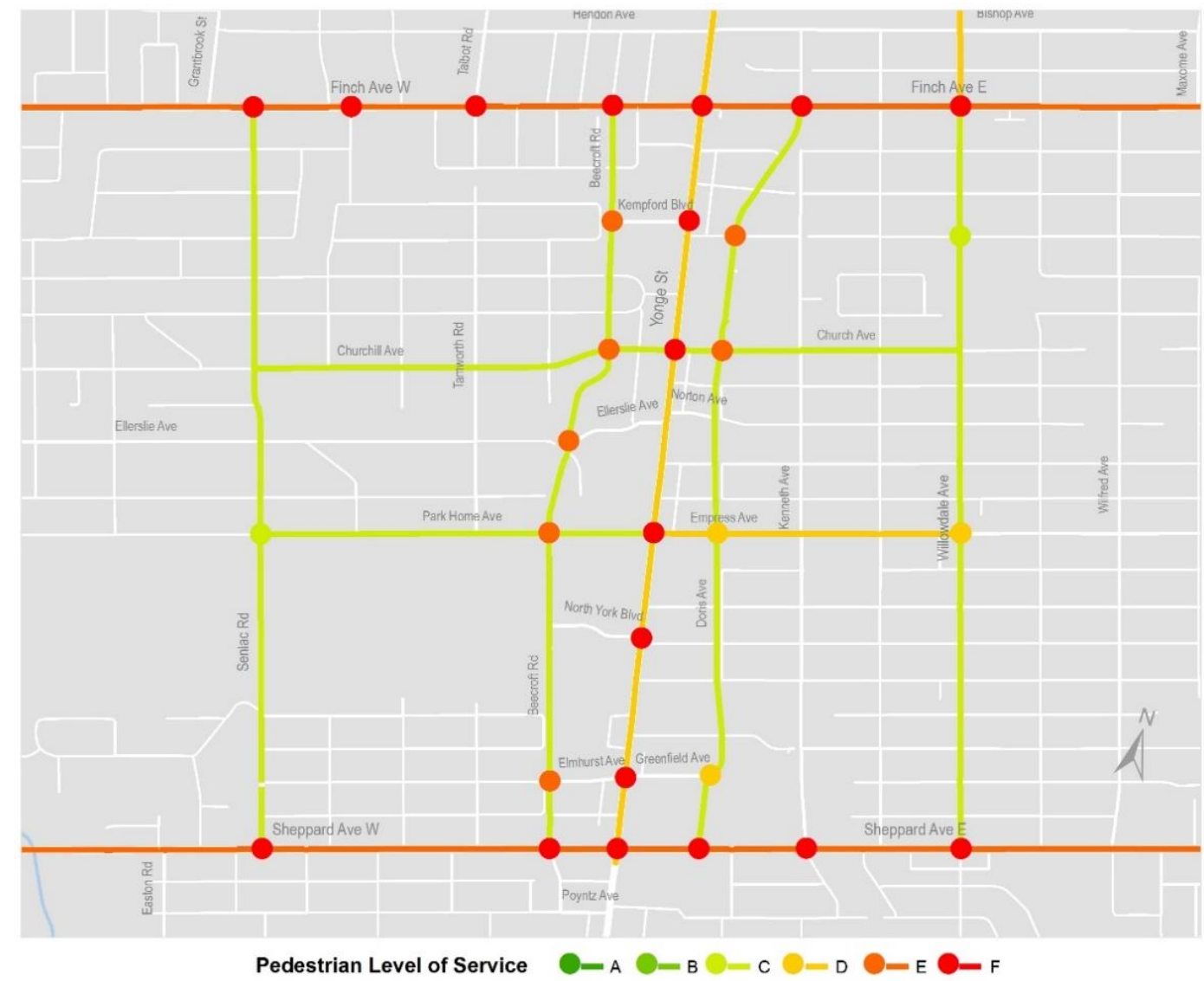

Figure 5-13: Existing Pedestrian Level of Service 


\subsubsection{Cycling Network Level of Service}

Following the same method, cycling network was evaluated for local major streets and intersections. Since no bike facilities exist in the study area, the overall result for the major streets are having the LOS F. The higher operating speed and no existing facilities are the major obstacles for cycling activity in this region. However, some collectors with lower number of travel lanes and speed limit have better for cycling, for instances, Church Ave and Park Home ave segments have the LOS B (Figure 5-14).

The intersections bike performance measure results are showing almost as like as pedestrian. Due to the higher number of lane crossing, right turning conflict, no exclusive cycling facilities in the intersection are making cyclist uncomfortable and very unsafe in almost all of the intersections. Some of the intersections along the Willowdale Aveneue and Doris Avene were found to be LOS C or D as the number of lanes is lower and conflict is relatively less. So, the overall existing performance is very low in the study area.

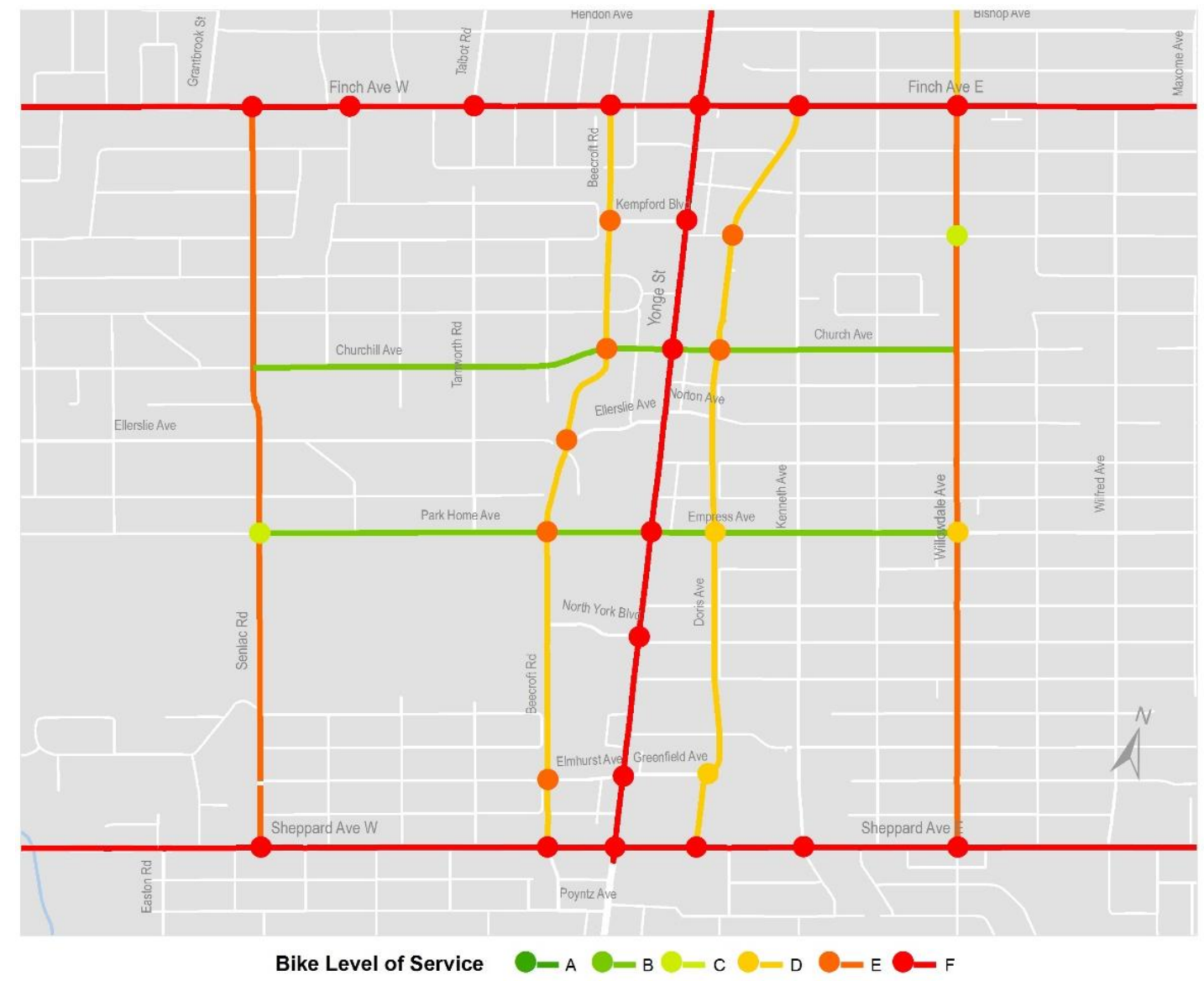

Figure 5-14: Existing Bike Level of Service 


\subsection{Estimating Active Transportation Demand}

\subsubsection{Existing Active Transportation Travel Demand}

From the results indicated above, it is apparent that active transportation potential of the urban growth center is very high. So, this study was focused more along Yonge corridor from Sheppard to Finch Avenue and also two N-S streets Beecroft Rd. on the east and Doris Ave on the west. For more detail analysis and potential active transportation demand estimation, these streets corridor along with eastwest collector streets (Churchill Ave, Church Ave, Park Home Ave.), were considered for the further analysis.

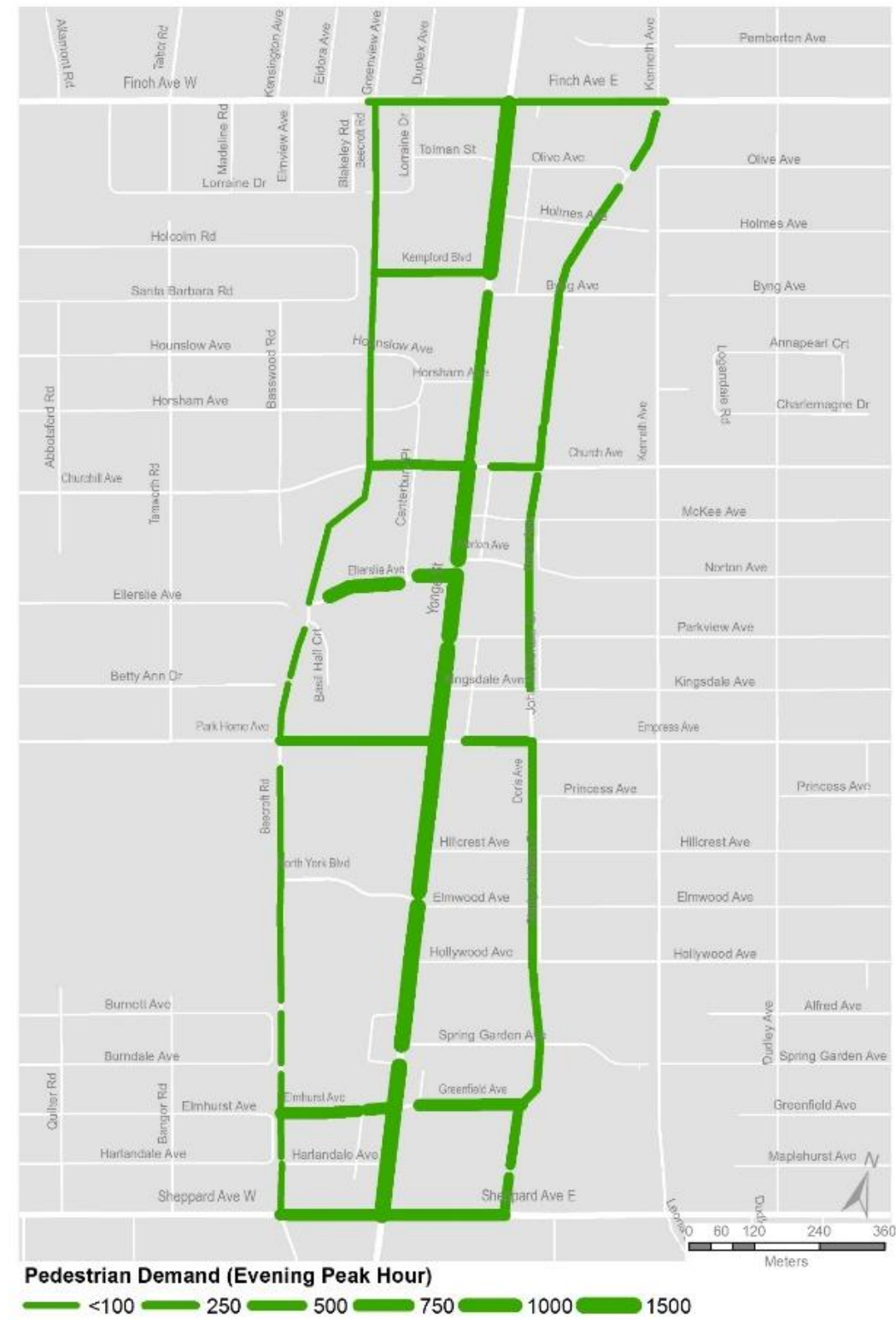

Figure 5-15: Existing Pedestrian demand on the links 


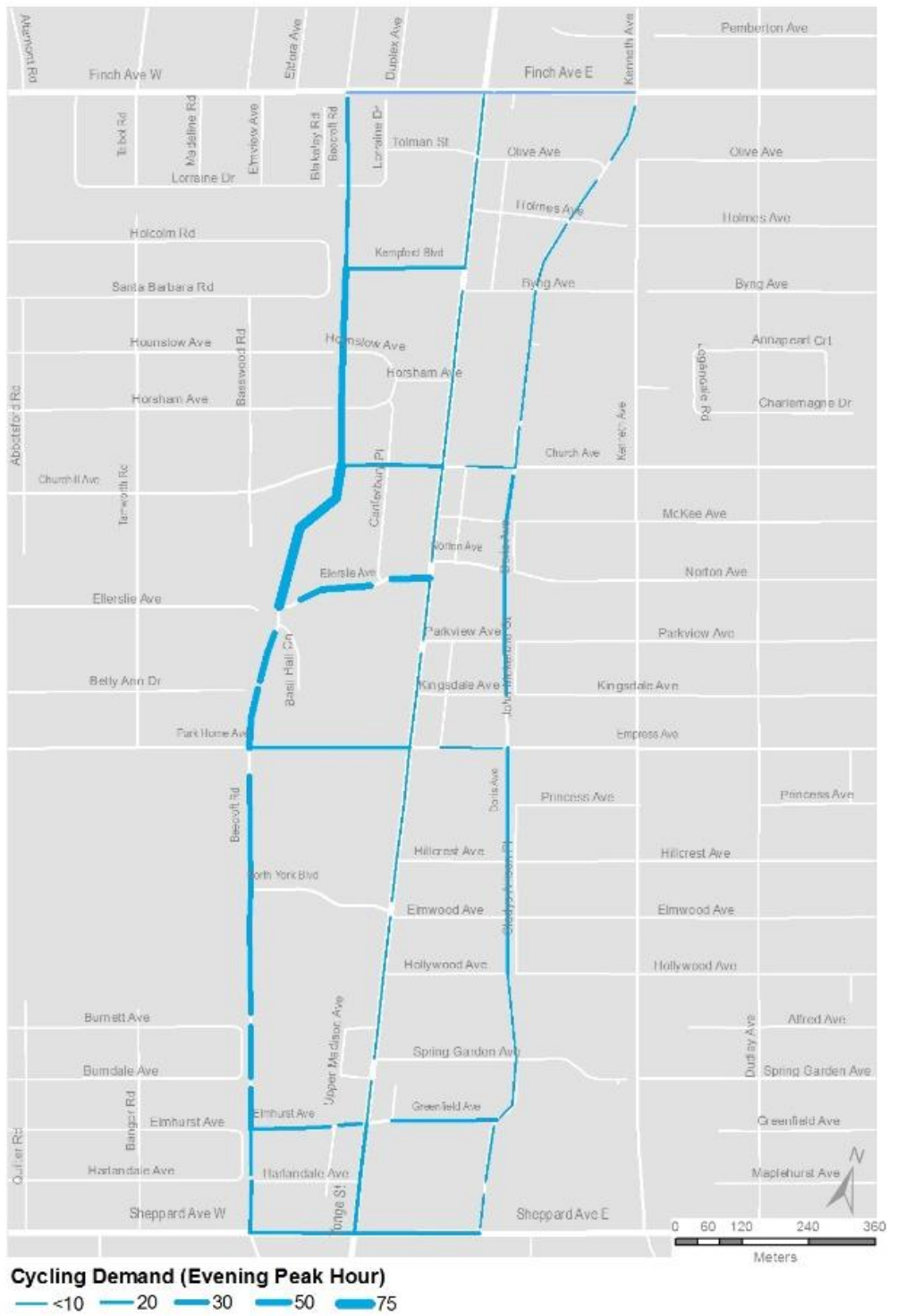

Figure 5-16: Existing Bike Demand on the links

The existing demand for pedestrian on the sidewalk and cycling on the links were estimated based on the pedestrian and cycling crossing volume from signalized intersection peak hour volume. For simplicity of calculation, it was assumed that the cross-walk pedestrian volume splits 50:50 in the sidewalk along the streets on both directions. The figures show that the existing pedestrian demand is comparatively higher on the Yonge street corridor and on the other hand the Beecroft Avenue has higher bike demand than that of others. Pedestrian volume is relatively higher on the east-west minor streets as they feel safer on those streets where as existing cycling demand is very low on the Yonge street. The reason is because due to higher operating speed and unsafe condition for cyclist on arterial streets. 


\subsubsection{Estimation of Potential Trips}

\subsubsection{Pedestrian Potential Trips}

For measuring the pedestrian and cycling potential demand, the existing trip data was considered using different modes of transportation. From the TTS survey data, the figure illustrates the existing mode share in the study area. The auto mode share dominates with $61 \%$ in total even though the trip distance is within $1 \mathrm{~km}$, which is walkable. At present, the walking mode share is only $31 \%$, and all other short auto trips can be converted to make 100\% walking trips. However, there might be some exceptional cases in which people need to use their vehicle for exclusive working purpose, such as, carrying heavy goods and/or for the movement of older/disable people. Therefore, it could be over estimation, but it was assumed that anyone can manage to walk up to $1 \mathrm{~km}$ regardless of the trip purpose.

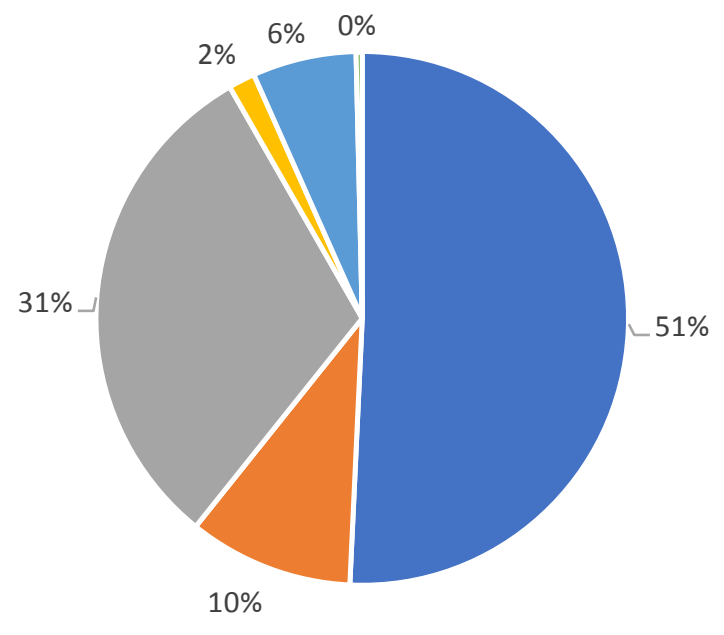

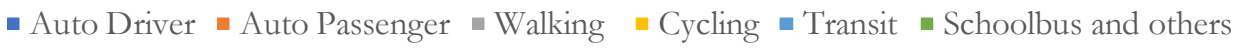

Figure 5-17: Existing Mode share for evening peak period and trip distance up to $1 \mathrm{~km}$

The criteria or assumptions used for the potential pedestrian trip conversion are as below.

- The trips are shorter than $<1 \mathrm{~km}$.

- The existing trips are done by Auto driver or Auto Passenger and Taxi.

- Transit trips are not converted to potential pedestrian trip as some part of transit trips are still required walking to/from the bus/transit stops.

- Existing Walking and Cycling trips are excluded from the potential trip conversion.

- Following these criteria 100\% trips by Auto and Taxi users are considered as the potential trips for the walking trips. 
By using the above criteria, total around 4000 trips can be possible to consider as potential walking trips in the zone surrounded by the Drewry and Cummer Ave in the North, Highway 401 and natural river boundary in the South, Bathurst and Bayview in the West and East respectively during evening peak period (Figure 5-18). Then multiplying the peak hour ratio by 0.6 , the total peak hour trip was estimated approximately 2400 trips. The area within and at the N-W corner of the North York Centre have the highest potential for the walking trips as the people make most of the short trips (about 700 trips) using auto. Other than that, the zones along the Yonge St. corridor or mixed use areas are not as potential as the surrounding residential zones, as they have already making their short trips by walking, cycling or transit.

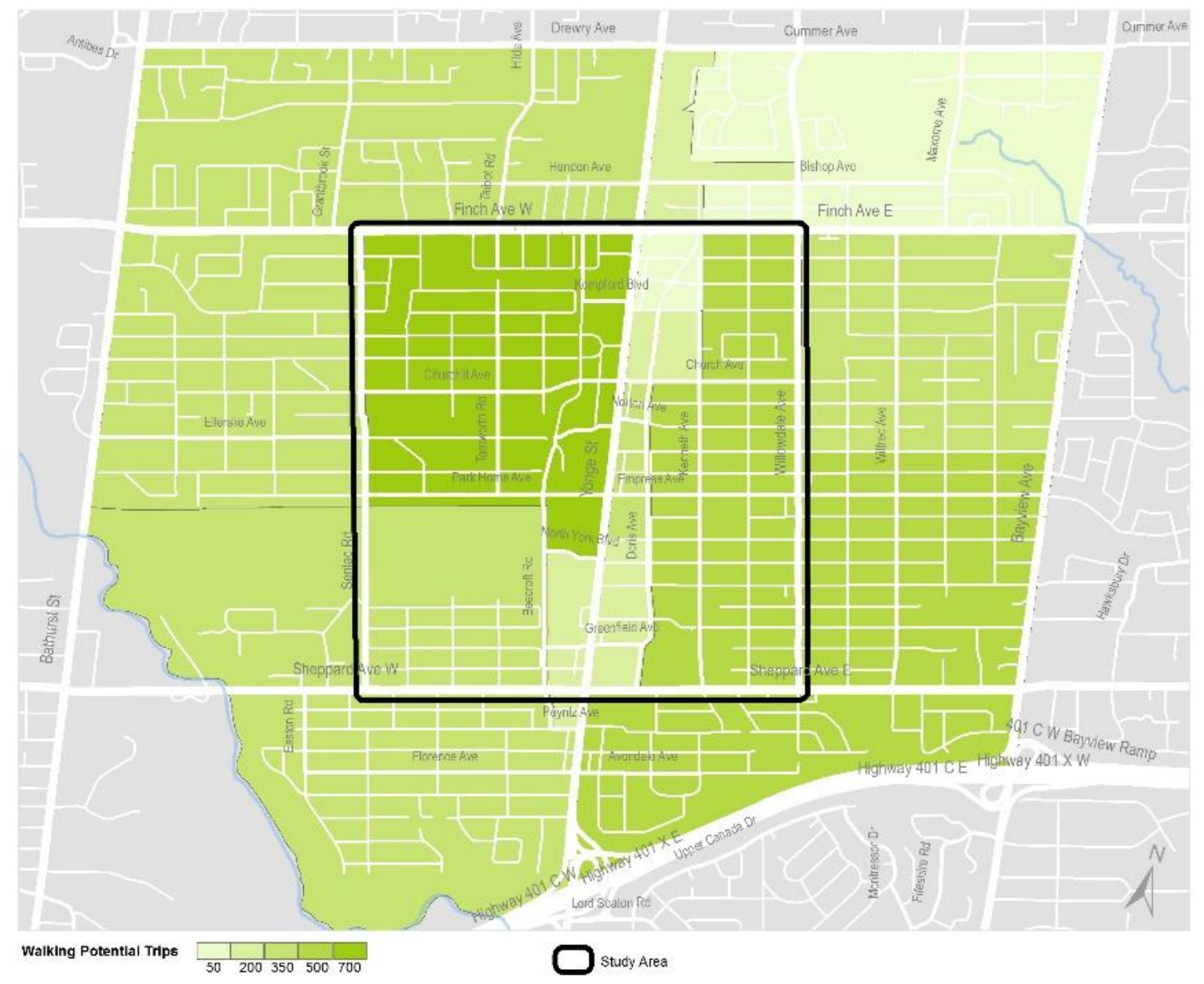

Figure 5-18: Walking potential trips for census zones 


\subsubsection{Cycling Potential Trips}

Current mode shares within 1-5 km trip distance in the study area is depicted in the graph below where car mode is $75 \%$ and walking constitutes about $10 \%$ trips. Although there are three subway stations in the study area, the transit share is only 14\%. The existing auto users for the short trips can be potential for the cycle trips, which is only $1 \%$ at present.

The criteria or assumptions used for the potential cycling trip conversion are as below.

- The trip distance is within1-5km or 20-30 min cycling distance.

- The existing modes are mainly Auto driver, Auto passenger and Taxi users.

- Transit trips are not converted to potential pedestrian trip.

- Existing Walking and Cycling trips are excluded.

- Almost 50\% trips are considered that could be potential for the cycling.

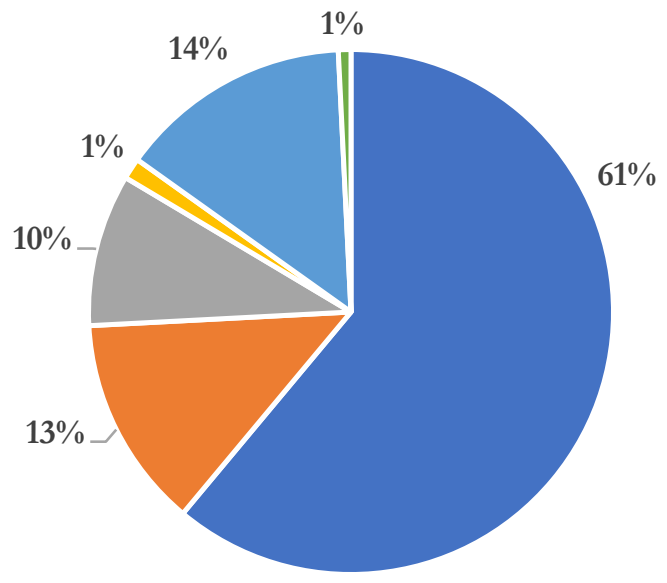

- Auto Driver $=$ Auto Passenger $\|$ Walking $\|$ Cycling $\|$ Transit $\|$ Schoolbus and others

Figure 5-19: Existing Mode share for evening peak period and trip distance 1-5 km 


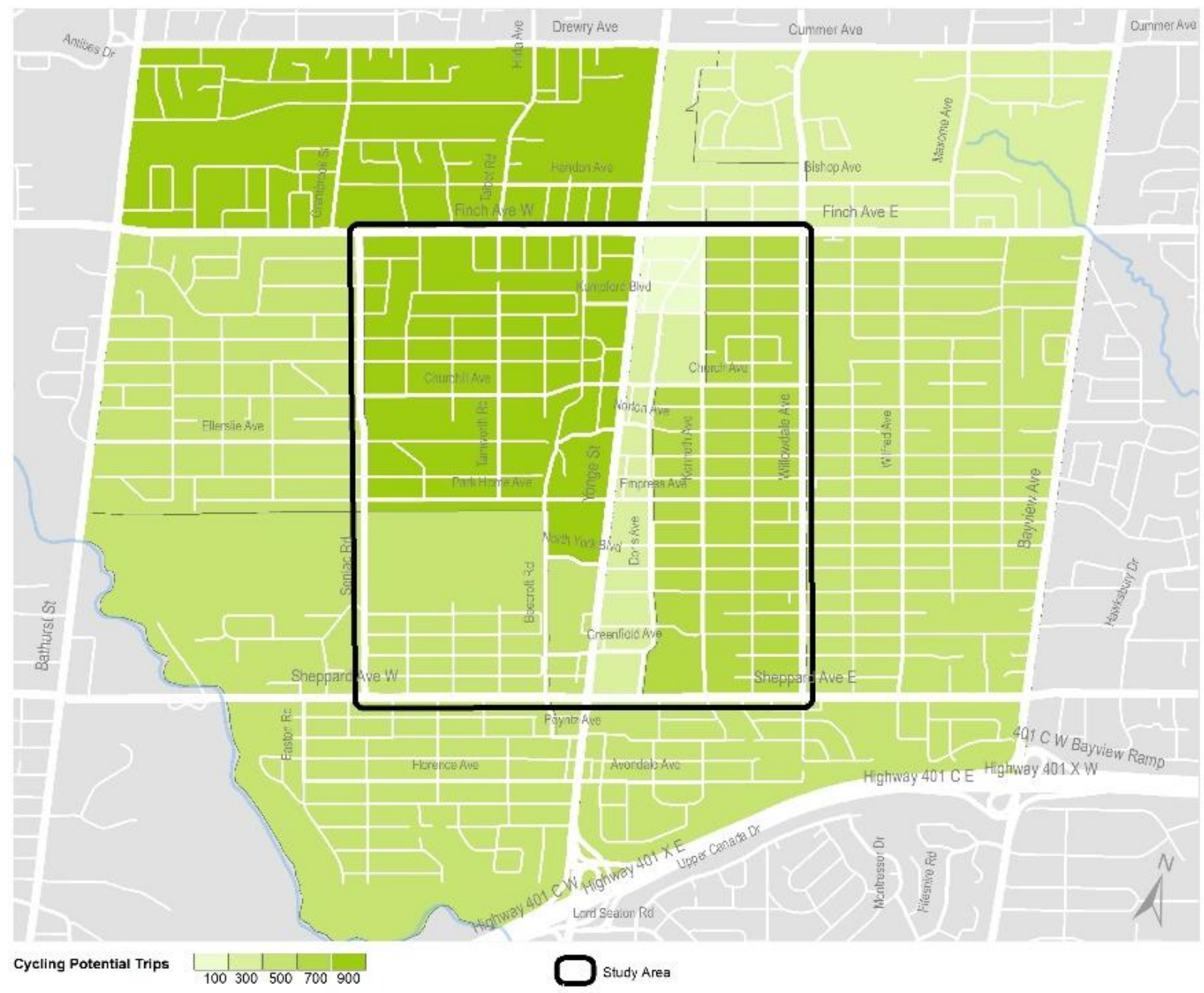

Figure 5-20: Cycling potential trips for census zones

By considering the above criteria, total around 7000 trips can be potentially considered as the cycling trips in the study area census zones during the evening peak period. Then by multiplying with peak hour ratio 0.6, the total peak hour trip is estimated that is roughly 4200 trips. However, not all the trips can be easily considered as the potential trips for bicycle. Assuming that $50 \%$ trips from this potential trip number could be transferred to bicycle mode, the potential network demand was estimated. 


\subsubsection{Potential Active Transportation Demand}

The total potentials trips were then converted to the potential demand using the ratio of signalized intersection existing demand within a census zone. For instance, if there are 4 signalized intersections within a census zone and the percentage of existing demand are $50 \%, 25 \%, 15 \%$ and $10 \%$ respectively corresponding to the total volume, the potential trips were distributed using the same percentage on the top of the existing demand. Thus, the potential pedestrian and cycling demand were estimated and assigned to the network. The estimated potential network demands for pedestrian and cycling are illustrated in Figure 5-21 and Figure 5-22. Pedestrian potential demand is very high on the Yonge street corridor whereas cycling demand is higher on the Beecroft corridor.

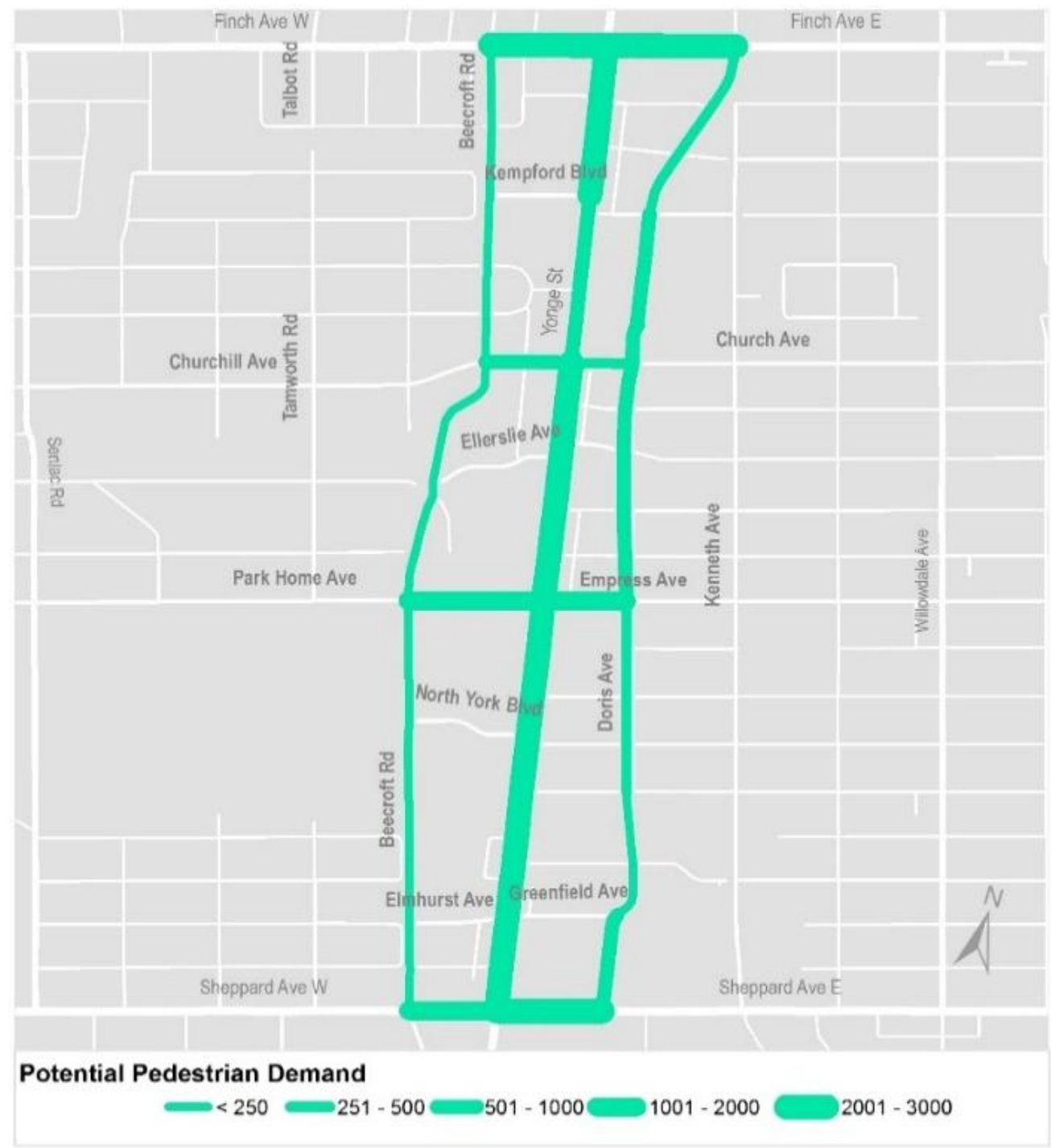

Figure 5-21: Potential Pedestrian Demand 


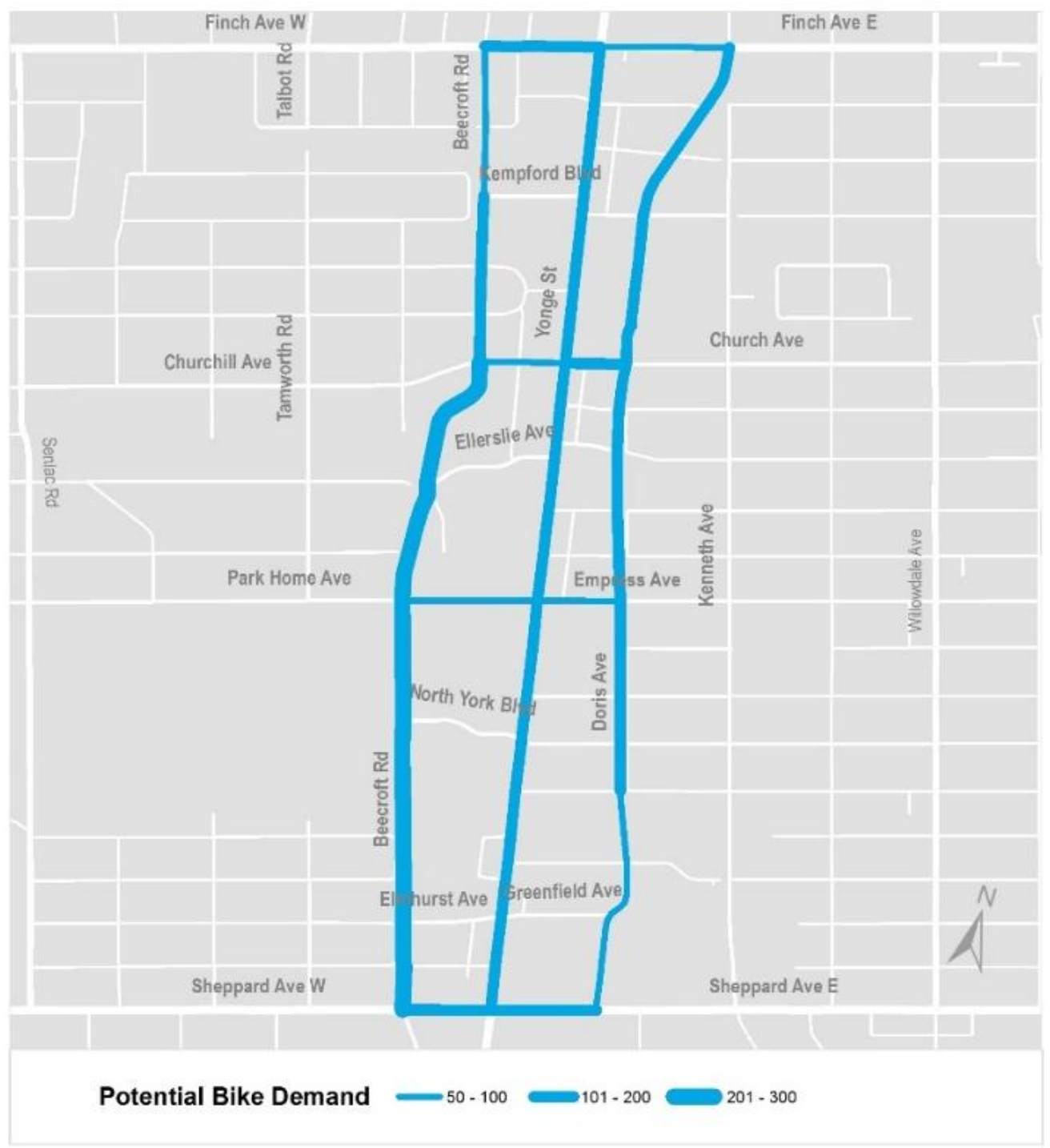

Figure 5-22: Potential Cycling Demand

\subsection{Evaluate Potential Demand Network Condition}

The potential network demand with the existing network facilities were evaluated using the HCM methodology for pedestrian and bike LOS. Potential pedestrian flow rate per hour was taken into consideration for measuring the potential pedestrain LOS (PLOS). Pedestrain and Bike LOS calculator were used to measure level of services based on the HCM method, developed by the League of Illinois Bicyclist (2017). . As the pedestrian comfortability depends on mostly the sidewalk facilities and operating speed on the roadway, the collector streets are more comfortable than the arterial streets. So, Beecroft Rd. and Doris Avenue are having higher level of comfortability, safety and mobility for pedestrain ( 
Figure 5-23).

In contrast, with the higher potential cycling demand and no cycling facilities at all, the BLOS is D for all the arterial and collector streets which means very uncomfortable and only a few people those are very strong cyclist can able to bike there. However, some of the local streets having lower operating speed and parking presents, make the LOS $\mathrm{C}$ which is comfortable and safe for the most of the user (Figure 5-24 ). Therefore, these streets need to redesign to make more pedestrain and bike friendly environment so that all means of transportation will get their desired level of service.

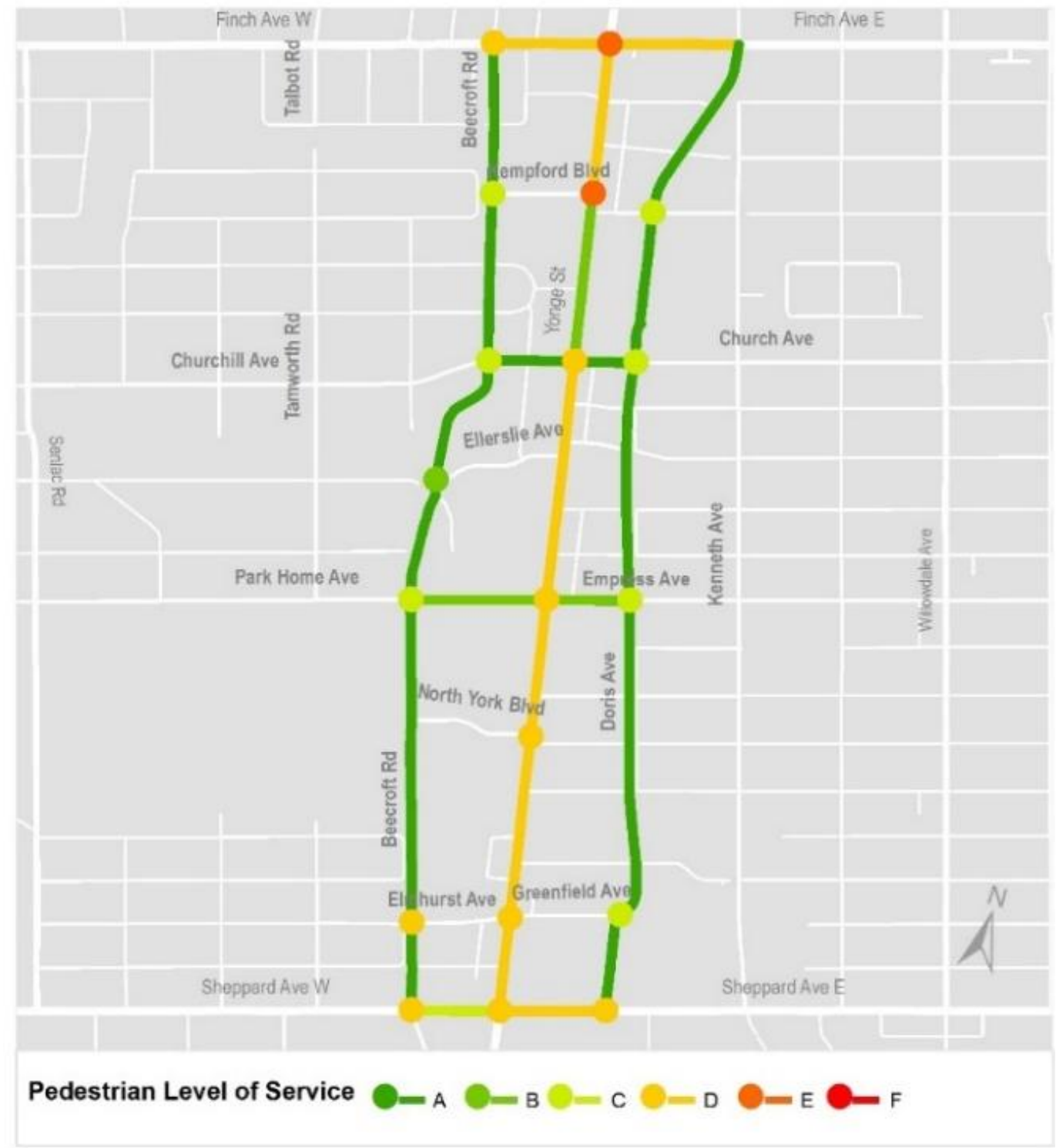

Figure 5-23: Pedestrian LOS for Potential Demand 


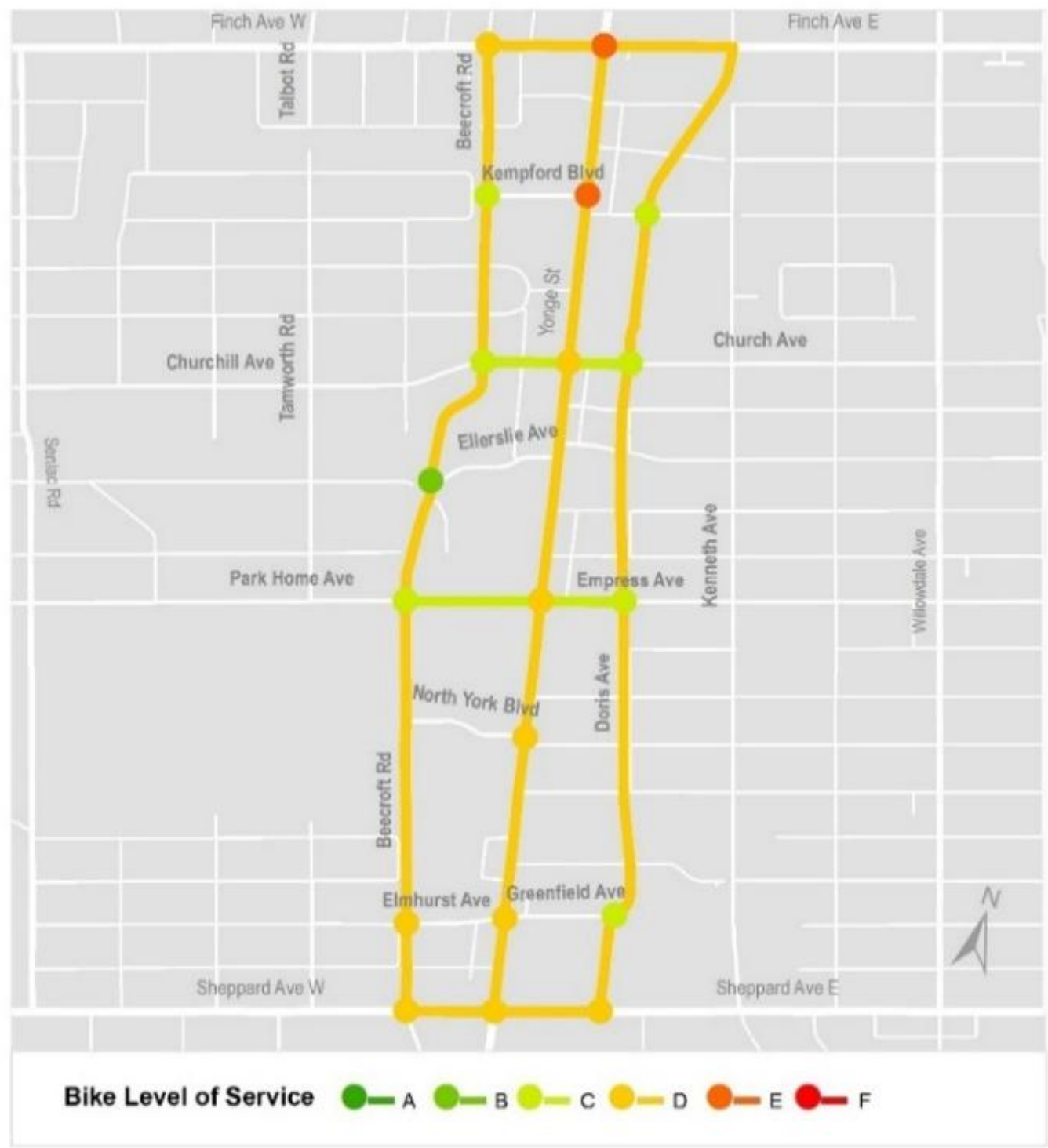

Figure 5-24: Bike LOS for Potential Demand 


\section{EVALUATION OF INFRASTRUCTURE IMPROVEMENTS}

\subsection{Review the Roadway Design Guidelines}

To accommodate the potential pedestrian and cycling demand on the streets and along the sidewalks, it is necessary to make some improvements. Several design guidelines have been reviewed to evaluate and redesign the existing streets emphasizing the active transportation users. For instances, NACTO Urban Street Design Guide, NACTO Bikeway Design Guide, Ontario Traffic Manual book 18: Cycling Facilities, TAC Geometric Design Guidelines and City of Toronto Vehicle Lane width guidelines were used to determine the design parameters. However, the TAC Geometric Design Guidelines (1999) is more than a decade old and do not account all transportation modes, especially walking and cycling (Transportation Association of Canada, 2017) (City of Toronto, 2015). Therefore, this study has considered mostly used design standards and the overall design parameters and standard measures are summarized in Table 6-1.

For improvement and redesigning of the streets, the total Right-of-way width is being considered fixed and lane configuration has the minor impact. The existing sidewalk width on most of the section of the streets are not in compliance with the recent guidelines and vehicle lane width are wider than the actual lane width proposed in the guidelines (NACTO, 2013) (City of Toronto, 2015). Thus the major potential improvements include widening sidewalks, introducing bike lanes and reducing lane width. In addition, many researchers suggest that for vehicle use, the narrow lanes are actually safer than the wider lanes and the extra space can be easily used for the multimodal road users mobility purposes (Karim, 2015). 
Table 6-1: Street with Walking and Cycling Facility Design Standards

\begin{tabular}{|c|c|c|c|c|c|}
\hline \multicolumn{6}{|c|}{ Street Design Parameters } \\
\hline \multirow{2}{*}{$\begin{array}{l}\text { Complete Street Design } \\
\text { Parameters }\end{array}$} & \multirow[t]{2}{*}{ Type of Lane } & \multirow[t]{2}{*}{ Road Type } & \multicolumn{3}{|c|}{ Lane Width } \\
\hline & & & $\max$ & target & $\min$ \\
\hline \multirow[t]{6}{*}{ Vehicle Travel Lane width } & \multirow[t]{2}{*}{ Inner/Through Lane } & Major Arterial & 3.6 & 3.2 & 2.8 \\
\hline & & Minor Arterial/Collector & 3.3 & 3.0 & 2.8 \\
\hline & \multirow[t]{2}{*}{ Curve lane (Left or Right-turn lane) } & Major Arterial & 3.6 & 3.2 & 2.8 \\
\hline & & Minor Arterial/Collector & 3.3 & 3.0 & 2.8 \\
\hline & Shared Curve lane (with Cycling facilities) & All road type & 4.3 & 4.3 & 2.8 \\
\hline & Two-way Left turn lane (TWLT) & & 3.2 & 3.0 & 2.7 \\
\hline \multirow[t]{8}{*}{ Blke lane width } & Shared Roadway with signed bike route & & 4.5 & 4.3 & 4.0 \\
\hline & \multirow[t]{3}{*}{ Conventional Bike lane } & One Travel lane & & 1.8 & 1.5 \\
\hline & & Two Travel lane & & 2.0 & 1.8 \\
\hline & & Adjacent to Parking lane & & $1.5 \mathrm{~m}$ Lane $+1.0 \mathrm{~m}$ buffer & $1.5 \mathrm{~m}$ Lane $+0.5 \mathrm{~m}$ buffer \\
\hline & \multirow[t]{4}{*}{ Separated Bike Lane } & Marked Buffer & & $1.8 \mathrm{~m}$ lane $+1.2 \mathrm{~m}$ buffer & $1.5 \mathrm{~m}$ lane $+0.5 \mathrm{~m}$ buffer \\
\hline & & Flexible Bollards & & $2.0 \mathrm{~m}$ lane $+1.2 \mathrm{~m}$ buffer & $1.5 \mathrm{~m}$ lane $+0.5 \mathrm{~m}$ buffer \\
\hline & & $\begin{array}{l}\text { Planters / Concrete Curb } \\
\text { / Median }\end{array}$ & & $2.0 \mathrm{~m}$ lane $+1.2 \mathrm{~m}$ buffer & $1.8 \mathrm{~m}$ lane $+0.5 \mathrm{~m}$ buffer \\
\hline & & On-Street Parking & & $1.8 \mathrm{~m}$ lane $+1.2 \mathrm{~m}$ buffer & $1.5 \mathrm{~m}$ lane $+0.8 \mathrm{~m}$ buffer \\
\hline \multirow[t]{5}{*}{ Sidewalk Width } & \multirow[t]{5}{*}{ Sidewalk zone } & $\begin{array}{l}\text { Through Zone } \\
\text { (Residential) }\end{array}$ & 2.1 & 1.8 & 1.5 \\
\hline & & $\begin{array}{l}\text { Through Zone } \\
\text { (Commercial Areas) }\end{array}$ & 3.7 & 3 & 2.5 \\
\hline & & Building Frontage & 0.9 & 0.5 & 0.4 \\
\hline & & $\begin{array}{l}\text { Street Furniture/Curb } \\
\text { Zone }\end{array}$ & 0.8 & 0.5 & 0.4 \\
\hline & & Edge/Buffer Zone & 0.9 & 0.5 & 0.4 \\
\hline
\end{tabular}




\subsection{Redesign the Streets for potential multimodal transportaion users}

Using the existing cross-sections, recommended redesign for the improvement of different streets is shown in the following figures. Improvement potentials for only arterial and collector streets are summarized here. Firstly, based on the high potential for active mode users especially cycling, Beecroft $\mathrm{Rd}$ is recommended to have a bike lane on both sides of the streets. The proposed design has also sidewalk width $2.1 \mathrm{~m}$ both side instead of $1.5 \mathrm{~m}$, reducing the lane width to the standard using the guidelines. The existing parking lane which is more than $4 \mathrm{~m}$ width is converted to the standard parking lane width of $3 \mathrm{~m}$.

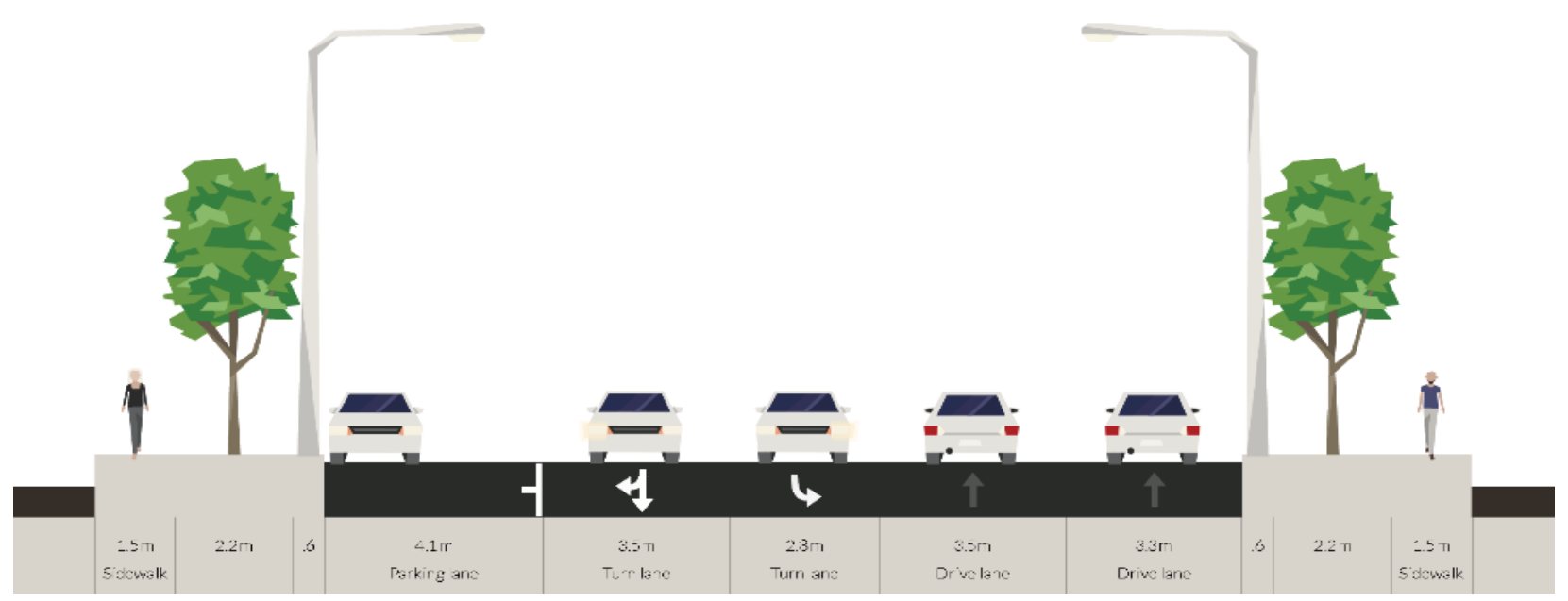

Figure 6-1: Existing Cross-section of Beecroft Rd at Sheppard Ave. W (Looking North)

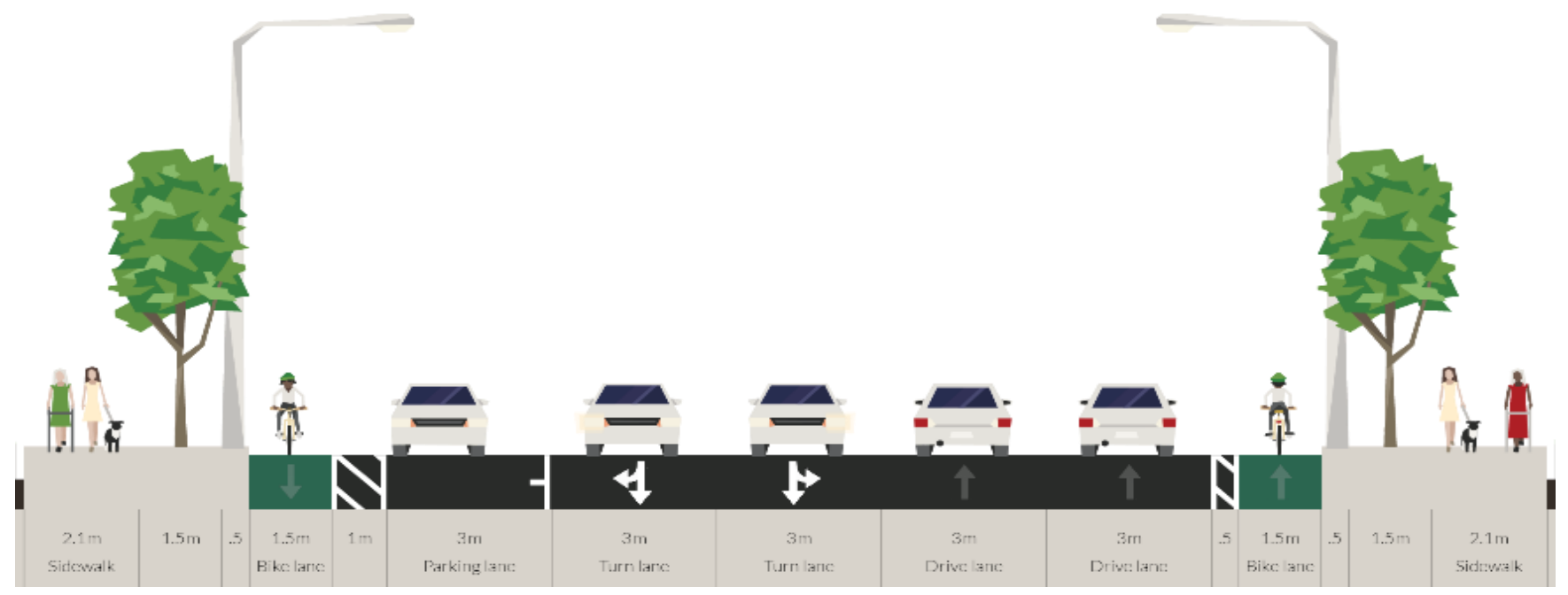

Figure 6-2: Recommended Cross-section of Beecroft Rd at Sheppard Ave. W (Looking North) 
The existing Yonge street segment has seven lanes in total for both direction at the intersections, with only $1.8 \mathrm{~m}$ sidewalk and no trees or buffer present (Figure 6-3). As the posted speed is high 50 $\mathrm{km} / \mathrm{hr}$ and with hihger Average Daily Traffic (ADT), a dedicated/protected cycle track is proposed in this street based on the OTM guidelines. The increased sidewalk width and trees zone are provided in order to make the street more pedestrian friendly also.

However, the total number of lane is reduced to five, which means two through lane is reduced from both direction of the street. Having convertion of all short trips and making streets for more pedestrian and cycle friendly, it is resonable to assume that the number of car traffic demand would be lower significantly. Moreover, according to the multimodal LOS guidelines auto mode needs to be LOS E which would be possible to achieve with lower traffic volume.

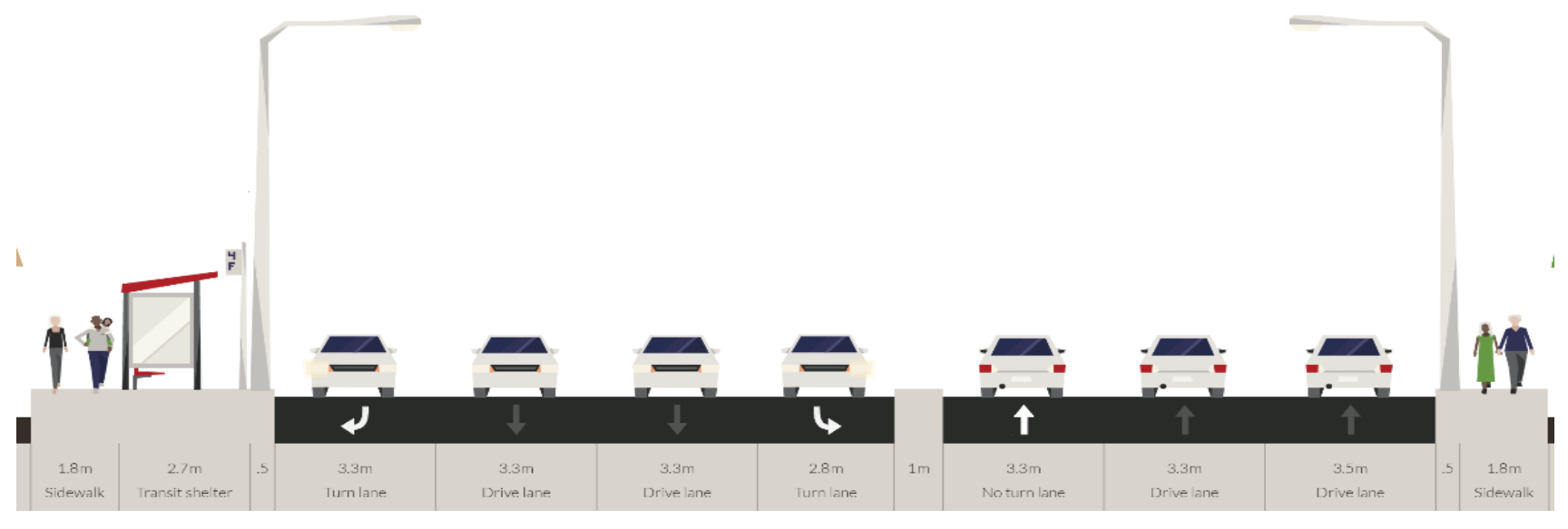

Figure 6-3: Existing Cross-section of Yonge Street at Sheppard Ave. (Looking North)

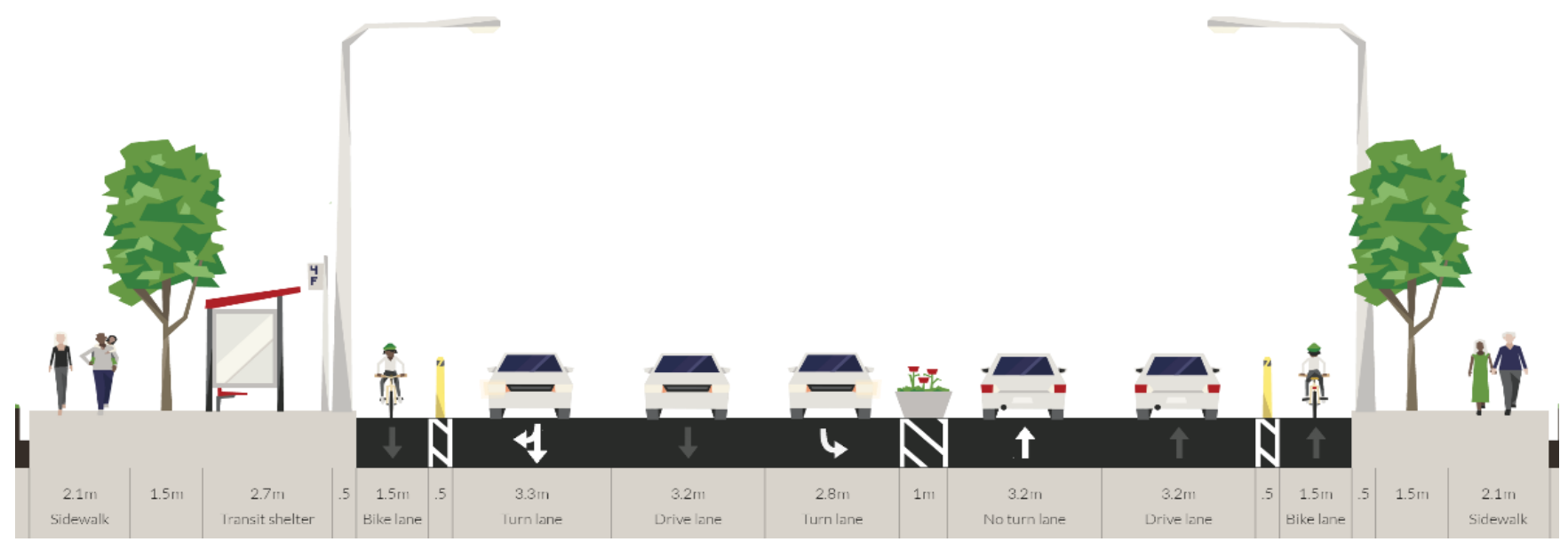

Figure 6-4: Recommended Cross-section of Yonge Street at Sheppard Ave. (Looking North) 
The Doris Ave. has two lanes on both direction with one parking lane and the sidewalk width is only $1.5 \mathrm{~m}$. Moreover, the lane width is also higher than the standard target width. A conventional bike lane with buffer has been proposed on both directions and tree zone is proposed to create safe and comfortable environment for the pedestrians and bike users.

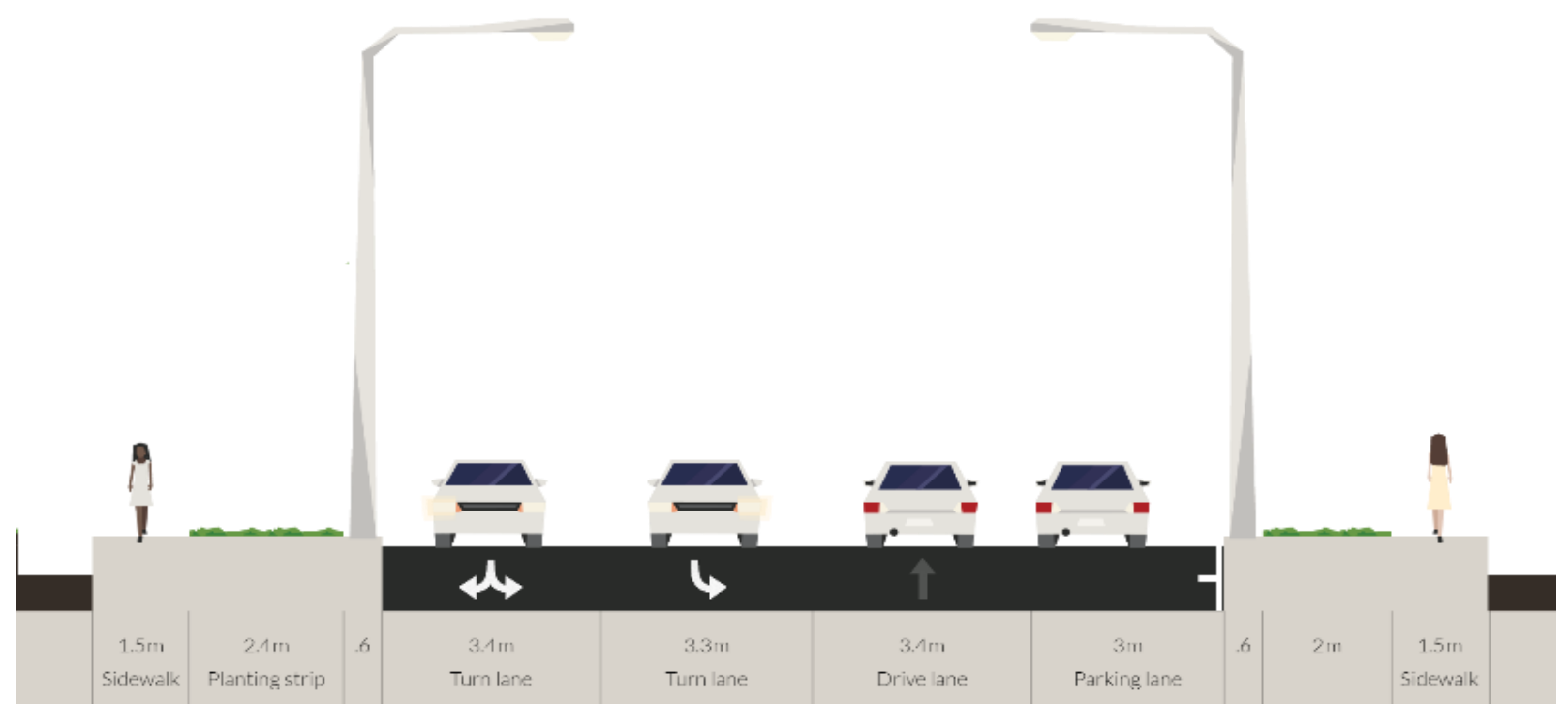

Figure 6-5: Existing Cross-section of Doris Ave. at Sheppard Ave. E (Looking North)

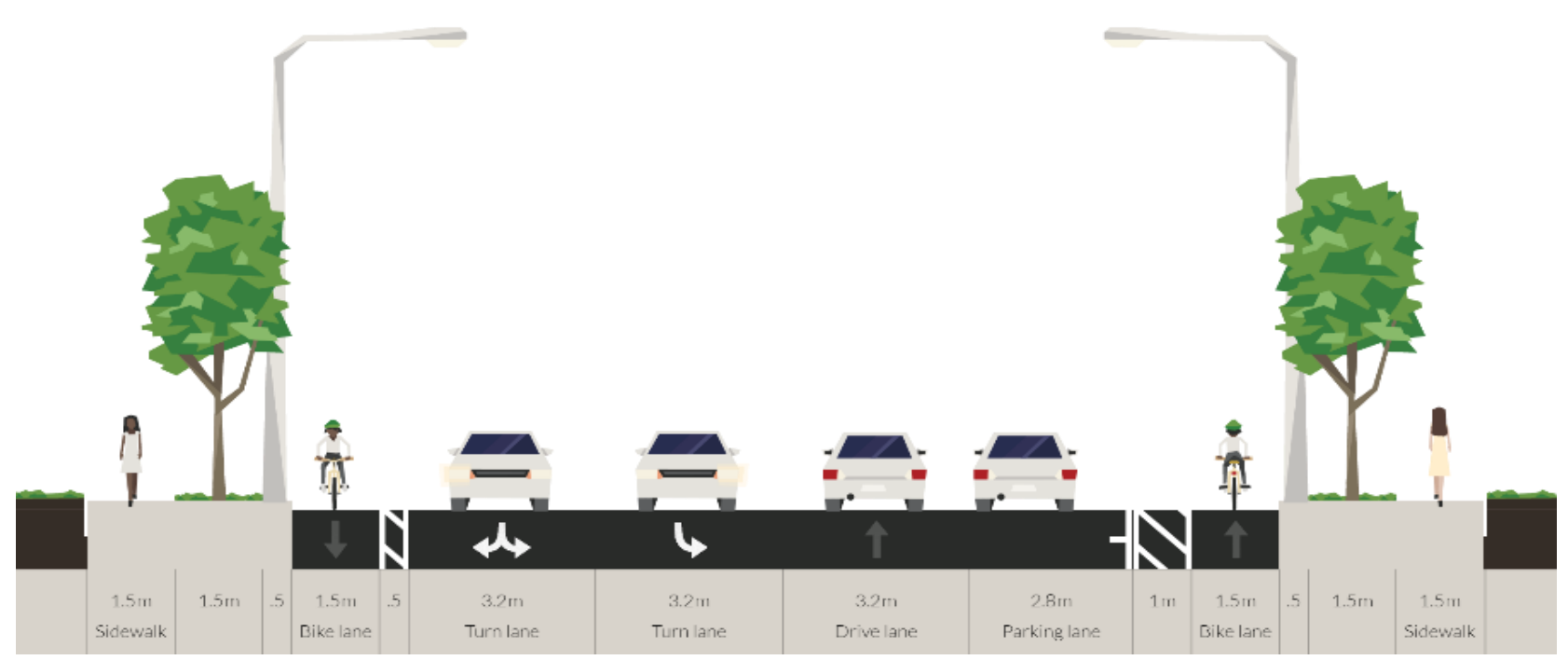

Figure 6-6: Existing Cross-section of Doris Ave. at Sheppard Ave. E (Looking North) 
The East-West collector streets are Church Street and Park Home Ave, where the operating speed and ADT are lower than that in the north-south streets. Unlike the north-south streets, the existing condition of these streets is more pedestrian friendly, such as, wider sidewalk and boulevard with trees (Figure 6-7). As the cycling demand is lower on those streets, shared bike lane has been proposed in one side of the street. A new bike lane has been proposed on Park Home Ave as the existing rightof-way permits.

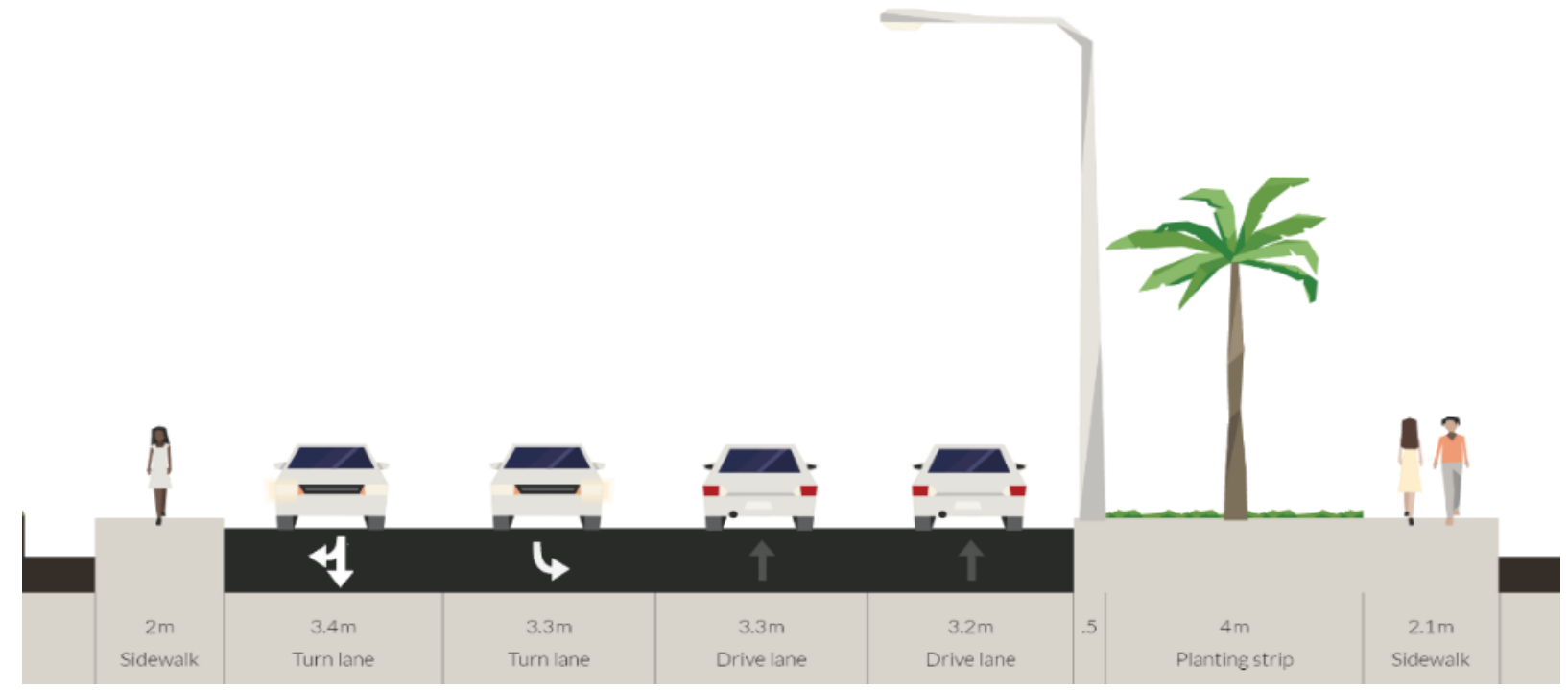

Figure 6-7: Existing Cross-section of Church St. at Doris Ave. (Looking West)

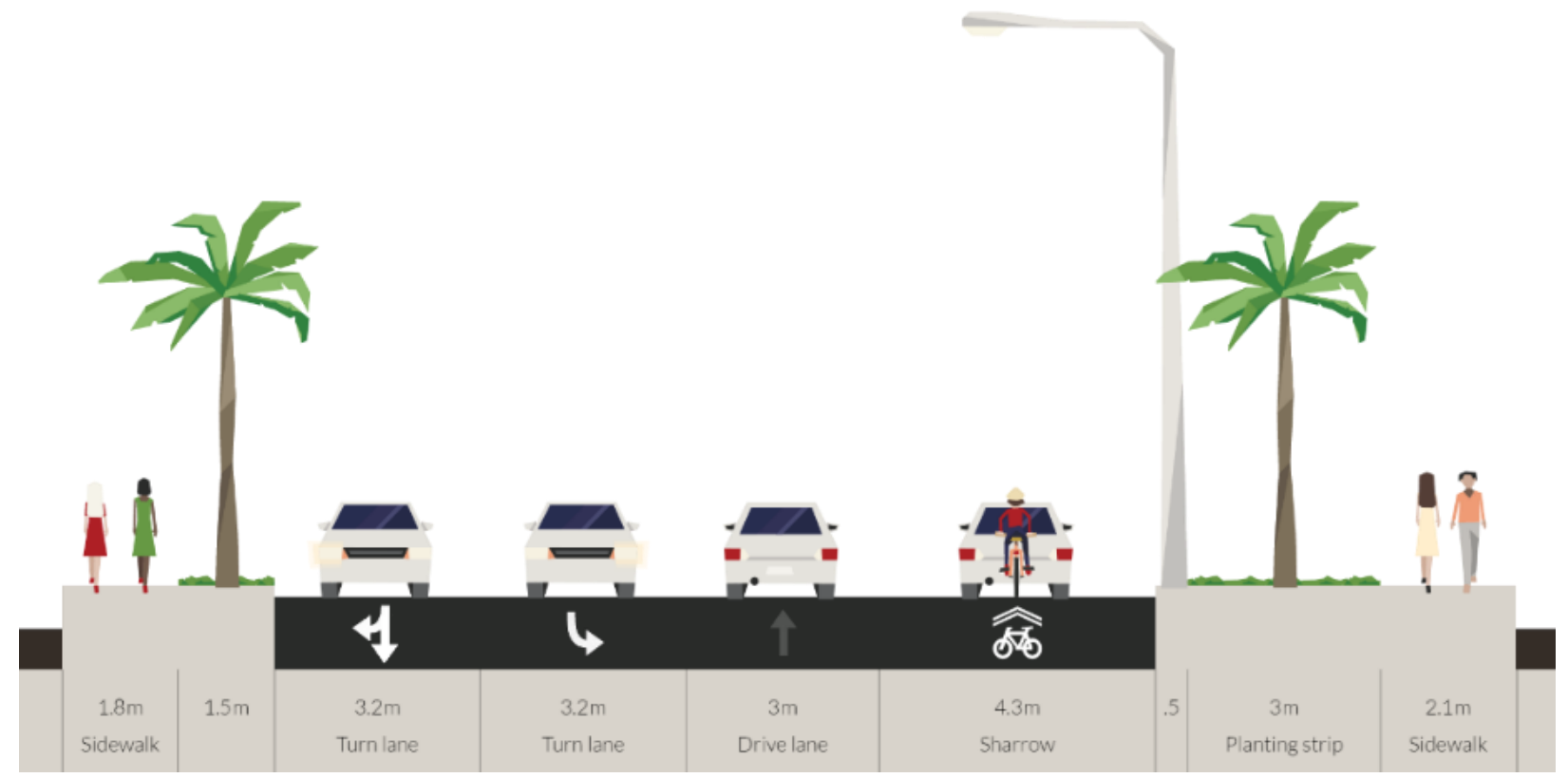

Figure 6-8: Recommended Cross-section of Church St. at Doris Ave. (Looking West) 


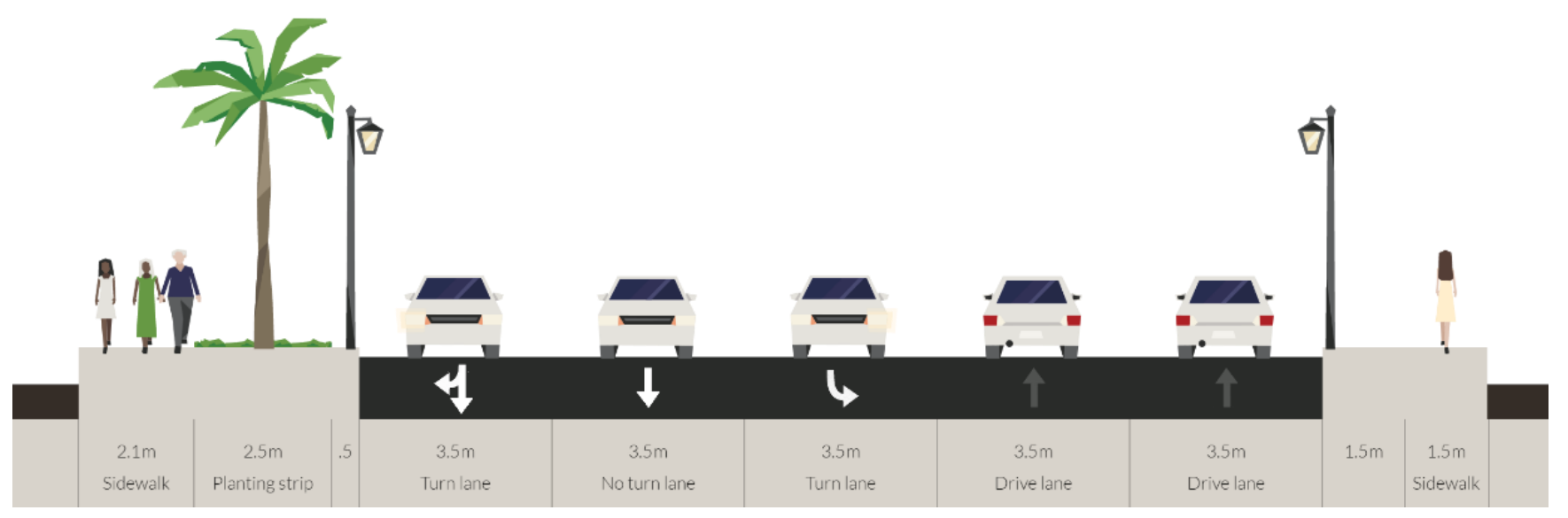

Figure 6-9: Existing Cross-section of Park Home Ave. at Beecroft Rd. (Looking East)

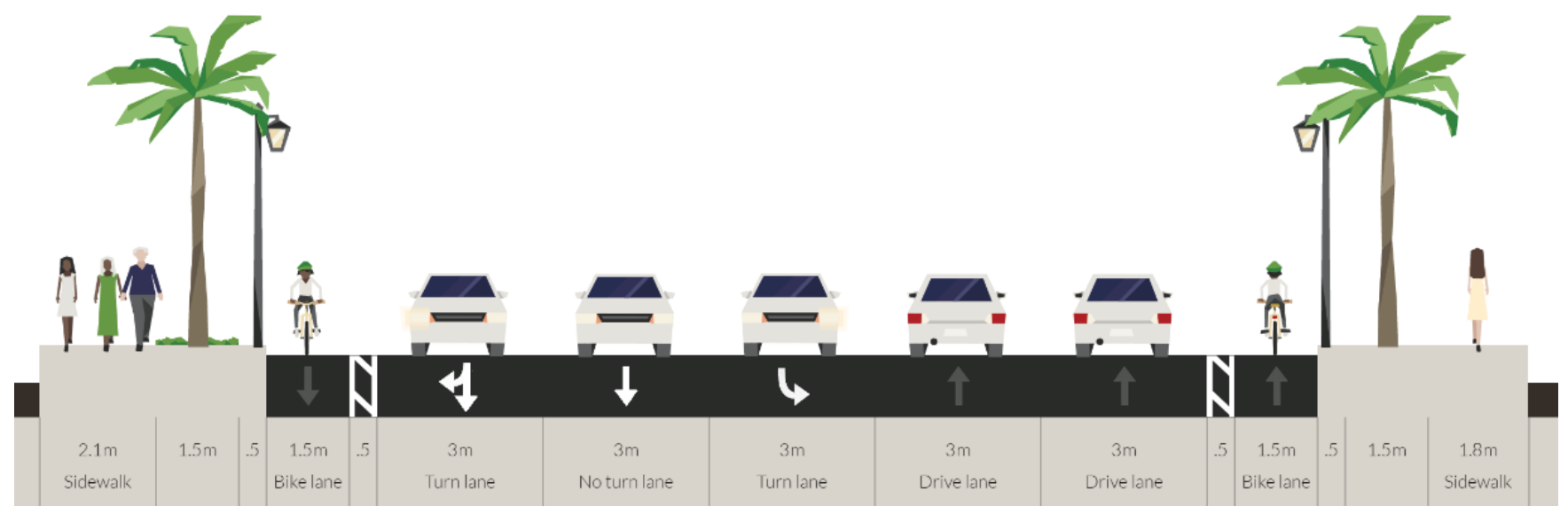

Figure 6-10: Recommended Cross-section of Park Home Ave. at Beecroft Rd. (Looking East)

The overall evaluation on performance of the streets with different links for pedestrians and bikes are summarized in Table 6-2. As it has been mentioned earlier that most of the streets segments are within the $600 \mathrm{~m}$ catchment areas of rapid transit stations or $300 \mathrm{~m}$ catchment area of schools, which are high generator for the active modes of transportation. Therefore, the desired LOS for pedestrian is LOS A and Bike is LOS B. However, after all the improvement/redesign, it is possible to achieve pedestrian LOS C in the arterial streets and LOS B in the collector streets. Since, Yonge Street has still high auto uses and operating speed, it is not possible to improve to the desired level. The best way to improve the quality is possible by incorporating traffic calming measures, such as, reducing the speeds from the current posted speeds. By reducing the speed limit to $30 \mathrm{~km} / \mathrm{hr}$, it would be possible to achieve their desired/target LOS A and B respectively for pedestrian and cycling. 


\begin{tabular}{|c|c|c|c|c|c|c|c|c|c|c|c|}
\hline \multicolumn{4}{|c|}{ Streets } & \multicolumn{2}{|c|}{ Existing Condition } & \multicolumn{2}{|c|}{$\begin{array}{l}\text { Potential } \\
\text { Scenario }\end{array}$} & \multicolumn{2}{|c|}{$\begin{array}{c}\text { Desired } \\
\text { Performance }\end{array}$} & \multicolumn{2}{|c|}{$\begin{array}{l}\text { Performance after } \\
\text { Improvement }\end{array}$} \\
\hline $\begin{array}{l}\text { Street } \\
\text { Direction }\end{array}$ & Corridor & $\begin{array}{l}\text { Street } \\
\text { Type }\end{array}$ & Segment & $\begin{array}{l}\text { Existing } \\
\text { PLOS }\end{array}$ & $\begin{array}{l}\text { Existing } \\
\text { BLOS }\end{array}$ & $\begin{array}{l}\text { PLOS } \\
\text { with } \\
\text { Potential } \\
\text { Demand }\end{array}$ & $\begin{array}{l}\text { BLOS } \\
\text { with } \\
\text { Potential } \\
\text { Demand }\end{array}$ & $\begin{array}{l}\text { Desired } \\
\text { PLOS }\end{array}$ & $\begin{array}{l}\text { Desired } \\
\text { BLOS }\end{array}$ & $\begin{array}{l}\text { PLOS } \\
\text { Achieved }\end{array}$ & $\begin{array}{l}\text { BLOS } \\
\text { Achieved }\end{array}$ \\
\hline \multirow{13}{*}{$\begin{array}{l}\text { North - } \\
\text { South } \\
\text { Streets }\end{array}$} & \multirow{6}{*}{ Beecroft Road } & \multirow{6}{*}{ Collector } & $\begin{array}{l}\text { Finch- } \\
\text { Kempford }\end{array}$ & C & D & B & D & A & B & B & C \\
\hline & & & $\begin{array}{l}\text { Kempford- } \\
\text { Churchill }\end{array}$ & C & D & B & D & A & B & B & C \\
\hline & & & $\begin{array}{l}\text { Churchill- } \\
\text { Ellerslie }\end{array}$ & C & D & B & D & A & B & B & C \\
\hline & & & $\begin{array}{l}\text { Ellerslie-Park } \\
\text { Home }\end{array}$ & C & D & B & D & A & B & B & C \\
\hline & & & $\begin{array}{l}\text { Park Home- } \\
\text { Elmhurst }\end{array}$ & C & D & B & D & A & B & B & C \\
\hline & & & $\begin{array}{l}\text { Elmhurst- } \\
\text { Sheppard }\end{array}$ & C & D & B & D & A & B & B & C \\
\hline & \multirow{6}{*}{ Yonge Street } & \multirow{6}{*}{$\begin{array}{l}\text { Major } \\
\text { Arterial }\end{array}$} & $\begin{array}{l}\text { Finch- } \\
\text { Kempford }\end{array}$ & D & $\mathbf{F}$ & D & D & A & B & C & C \\
\hline & & & $\begin{array}{l}\text { Kempford- } \\
\text { Churchill }\end{array}$ & D & $\mathbf{F}$ & D & D & A & B & C & C \\
\hline & & & $\begin{array}{l}\text { Churchill-Park } \\
\text { Home }\end{array}$ & D & $\mathbf{F}$ & D & D & A & B & C & C \\
\hline & & & $\begin{array}{l}\text { Park Home- } \\
\text { Elmwood }\end{array}$ & D & $\mathbf{F}$ & D & D & A & B & C & C \\
\hline & & & $\begin{array}{l}\text { Elmwood- } \\
\text { Elmhurst }\end{array}$ & D & $\mathbf{F}$ & $D$ & D & A & B & C & C \\
\hline & & & $\begin{array}{l}\text { Elmhurst- } \\
\text { Sheppard }\end{array}$ & D & $\mathbf{F}$ & D & D & $\mathbf{A}$ & B & C & C \\
\hline & Doris Avenue & Collector & Finch-Byng & C & D & B & D & A & B & B & B \\
\hline
\end{tabular}




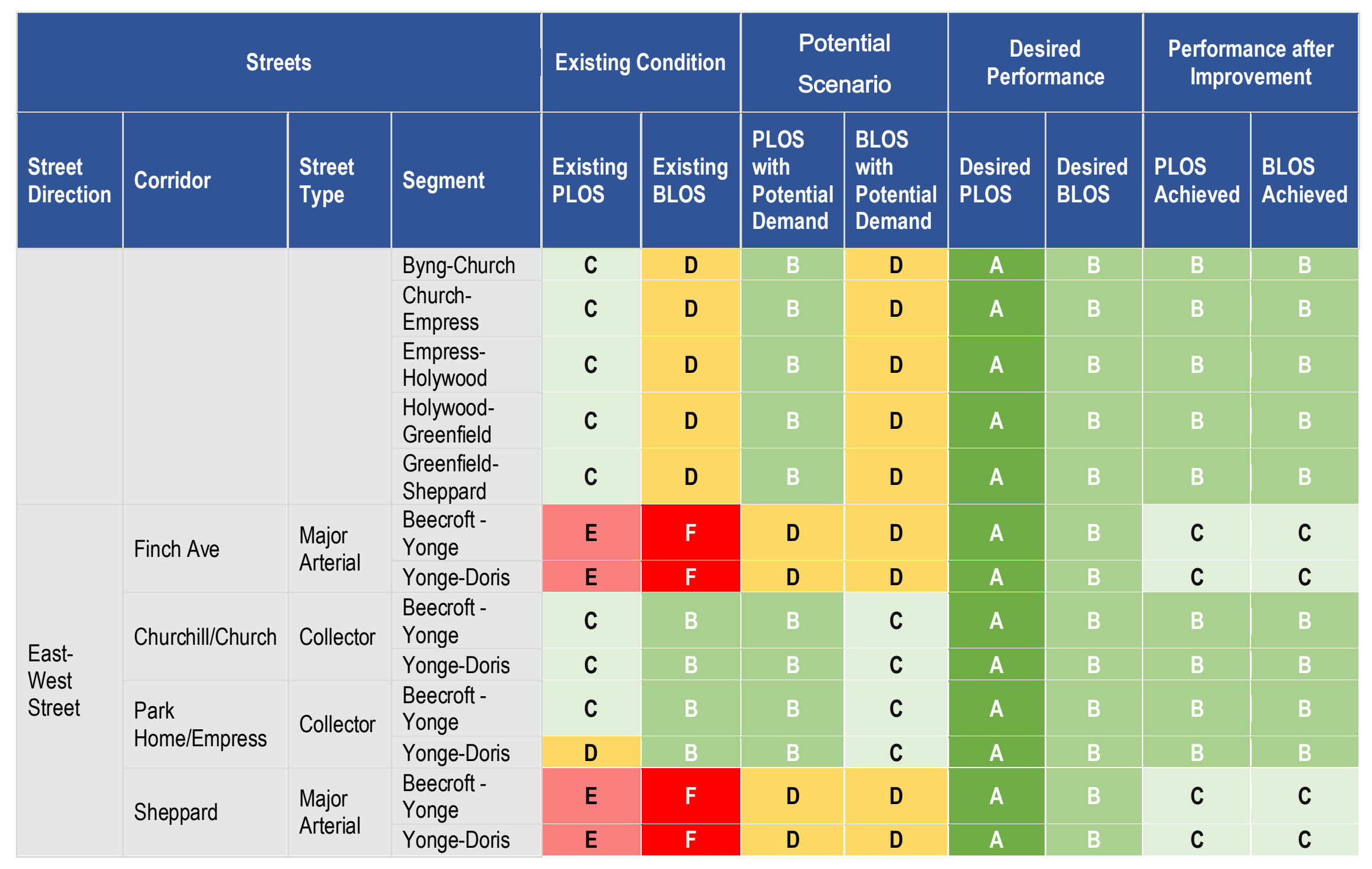




\section{CONCLUSIONS}

This study highlights the importance of a comprehensive methodology to address active transportation potential demand and evaluation of its infrastructure. This study has developed an integrated methodology framework for the assessment of the infrastructure requirements and quality for guiding the planners and engineers. Different quantitative methods recently developed by various researchers have been used in developing this method. The integrated method developed in this study has been successfully applied in the case study for evaluating the potential of walking and cycling. Eventually, a new street design has been recommended to improve livability of the area residents and visitors mobility choices.

Due to unavailability of sufficient walking and cycling count data, in some steps, this study had to rely on only signalized intersection volume data and some mid-block data on Yonge Streets to verify the sidewalk demand. However, the accuracy would be even better if all street segment pedestrian and cycling count data are available. Moreover, the study assumes that the potential trips are distributed as per signalized intersection under existing demand conditions and proportions. When trips from auto modes are converted to estimate distribution of active transportation trips potential, it could be impacted by different pattern and bahaviour.

Although the study considered connectivity, comfortability, convenience of the active transportation mode; safety analysis using crash statistics is another essential factor that needs to be considered in future studies to improve the proposed active transportation evaluation framework. 


\section{APPENDIX A: TRAFFIC VOLUME DATA}

\section{TIITRORNTO}

City of Toronto - Traffic Safety Unit

\section{Turning Movement Count Summary Report}

SHEPPARD AVE AT YONGE ST (PX 125)

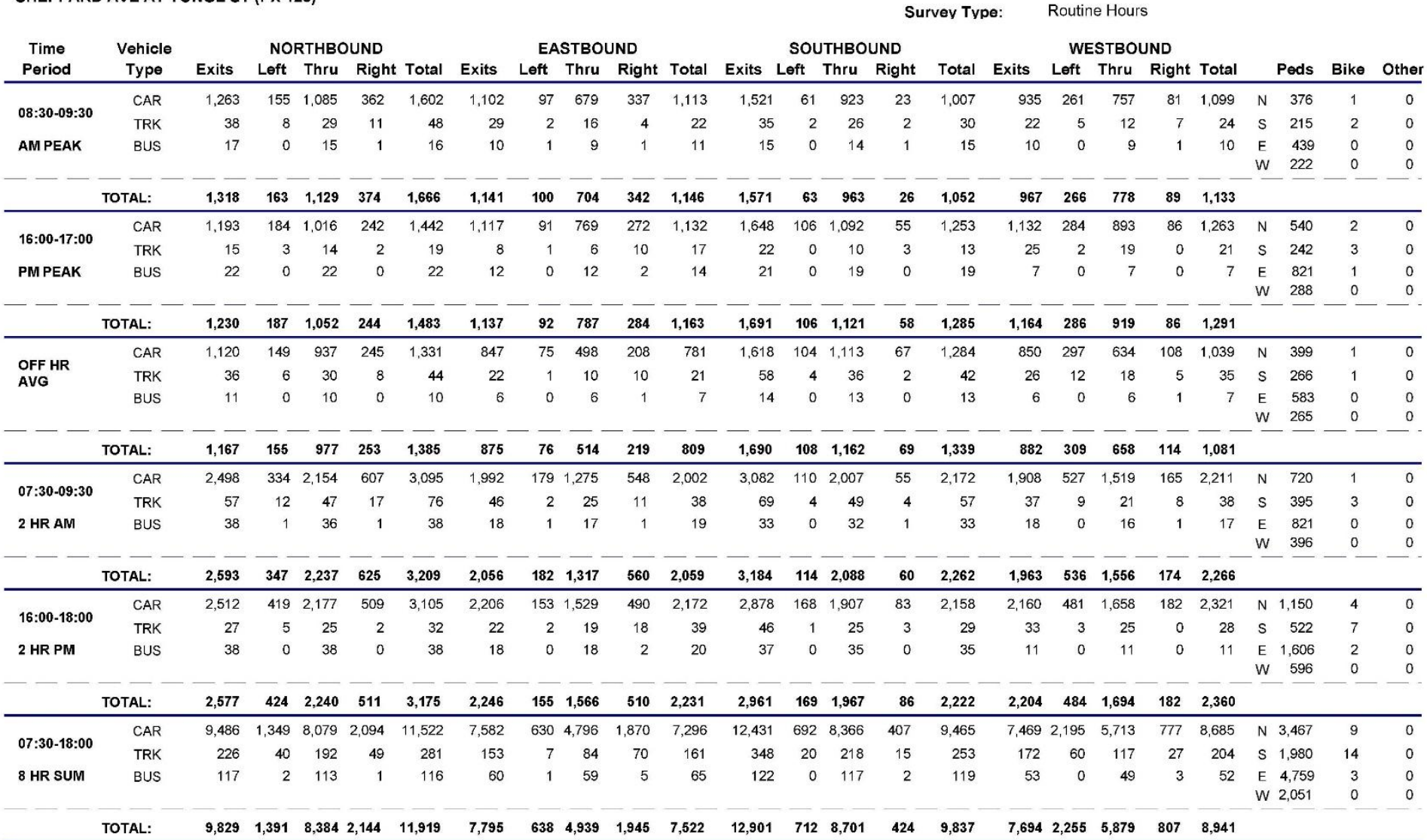

Total 8 Hour Vehicle Volume: $\mathbf{3 8 , 2 1 9}$ Comment:
Total 8 Hour Bicycle Volume: 26 
Turning Movement Count Summary Report

EMPRESS AVE AT PARK HOME AVE \& YONGE ST (PX 126)

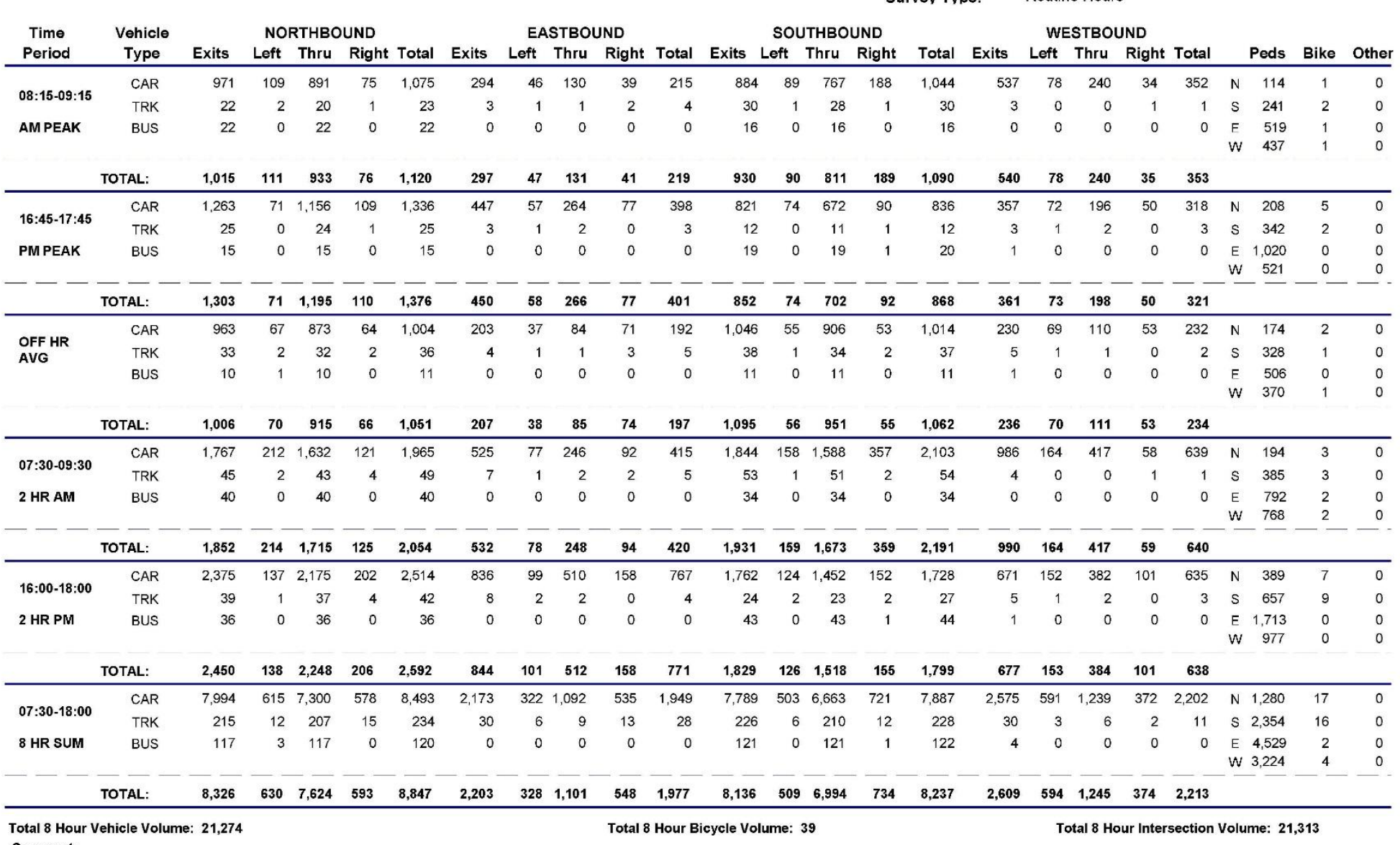


Turning Movement Count Summary Report

CHURCH AVE AT CHURCHILL AVE \& YONGE ST (PX 127)

\begin{tabular}{|c|c|c|c|c|c|c|c|c|c|c|c|c|c|c|c|c|c|c|c|c|c|c|c|c|c|}
\hline \multirow{2}{*}{$\begin{array}{l}\text { Time } \\
\text { Period }\end{array}$} & \multirow{2}{*}{$\begin{array}{c}\text { Vehicle } \\
\text { Type }\end{array}$} & \multirow[b]{2}{*}{ Exits } & \multicolumn{3}{|c|}{ NORTHBOUND } & \multirow[b]{2}{*}{ Total } & \multicolumn{5}{|c|}{ EASTBOUND } & \multicolumn{5}{|c|}{ SOUTHBOUND } & \multicolumn{5}{|c|}{ WESTBOUND } & \multirow{2}{*}{\multicolumn{2}{|c|}{ Peds }} & \multirow[b]{2}{*}{ Bike } & \multirow[b]{2}{*}{ Othe } \\
\hline & & & Left & Thru & Right & & Exits & Left & Thru & Right & Total & Exits & Left & Thru & Right & Total & Exits & Left & Thru & Right & Total & & & & \\
\hline \multirow{2}{*}{$08: 15-09: 15$} & CAR & 939 & 37 & 807 & 71 & 915 & 268 & 70 & 135 & 38 & 243 & 1,344 & 62 & 1,200 & 55 & 1,317 & 263 & 106 & 171 & 62 & 339 & $\mathrm{~N}$ & 115 & 1 & 0 \\
\hline & TRK & 28 & 0 & 27 & 0 & 27 & 1 & 0 & 0 & 1 & 1 & 38 & 1 & 36 & 0 & 37 & 2 & 1 & 2 & 1 & 4 & s & 58 & 1 & 0 \\
\hline \multirow[t]{2}{*}{ AM PEAK } & BUS & 22 & 0 & 22 & 1 & 23 & 1 & 0 & 0 & 0 & 0 & 16 & 0 & 16 & 1 & 17 & 1 & 0 & 0 & 0 & 0 & E & 174 & 0 & $\begin{array}{l}0 \\
0\end{array}$ \\
\hline & TOTAL: & 989 & 37 & 856 & 72 & 965 & 270 & 70 & 135 & 39 & 244 & 1,398 & 63 & 1,252 & 56 & 1,371 & 266 & 107 & 173 & 63 & 343 & & & & \\
\hline \multirow{2}{*}{$16: 30-17: 30$} & CAR & 1,255 & 38 & 1,139 & 85 & 1,262 & 368 & 59 & 225 & 29 & 313 & 884 & 58 & 783 & 46 & 887 & 308 & 72 & 224 & 57 & 353 & $\mathrm{~N}$ & 157 & 0 & 0 \\
\hline & TRK & 18 & 0 & 17 & 1 & 18 & 3 & 0 & 2 & 1 & 3 & 19 & 0 & 16 & 0 & 16 & 0 & 2 & 0 & 1 & 3 & $\mathrm{~s}$ & 112 & 0 & 0 \\
\hline \multirow[t]{2}{*}{ PM PEAK } & BUS & 16 & 0 & 16 & 0 & 16 & 0 & 0 & 0 & 0 & 0 & 20 & 0 & 20 & 0 & 20 & 0 & 0 & 0 & 0 & 0 & E & 450 & 0 & 0 \\
\hline & $\overline{\text { TOTAI. }}$ & 1289 & 38 & $-\overline{172}$ & 86 & $\overline{1296}$ & $\overline{371}$ & 59 & 227 & $\overline{30}$ & 316 & 923 & 58 & 819 & 46 & $\overline{793}$ & 308 & 74 & 224 & 58 & 356 & & & & \\
\hline \multirow{4}{*}{$\begin{array}{l}\text { OFF HR } \\
\text { AVG }\end{array}$} & CAR & 973 & 26 & 869 & 30 & 925 & 158 & 52 & 77 & 29 & 158 & 1,039 & 51 & 956 & 40 & 1,047 & 148 & 54 & 82 & 52 & 188 & $\mathrm{~N}$ & 157 & 2 & 0 \\
\hline & TRK & 33 & 2 & 32 & 1 & 35 & 3 & 1 & 0 & 2 & 3 & 38 & 2 & 34 & 1 & 37 & 5 & 2 & 2 & 0 & 4 & s & 74 & 1 & 0 \\
\hline & BUS & 10 & 0 & 10 & 0 & 10 & 0 & 0 & 0 & 0 & 0 & 11 & 0 & 11 & 0 & 11 & 0 & 0 & 0 & 0 & 0 & E & 275 & 0 & 0 \\
\hline & TOTAL: & 1,016 & 28 & 911 & 31 & 970 & 161 & 53 & 77 & 31 & 161 & 1,088 & 53 & 1.001 & 41 & 1.095 & 153 & 56 & 84 & 52 & 192 & & & & \\
\hline \multirow{2}{*}{$07: 30-09: 30$} & CAR & 1,732 & 62 & 1,516 & 102 & 1,680 & 466 & 111 & 239 & 64 & 414 & 2,564 & 125 & 2,298 & 103 & 2,526 & 477 & 202 & 312 & 105 & 619 & $\mathrm{~N}$ & 161 & 3 & 0 \\
\hline & TRK & 52 & 2 & 45 & 0 & 47 & 3 & 4 & 1 & 3 & 8 & 60 & 2 & 55 & 1 & 58 & 7 & 2 & 4 & 3 & 9 & s & 93 & 2 & 0 \\
\hline \multirow[t]{3}{*}{2 HR AM } & BUS & 40 & 0 & 40 & 1 & 41 & 2 & 0 & 1 & 0 & 1 & 33 & 0 & 33 & 1 & 34 & 1 & 0 & 0 & 0 & 0 & E & 270 & 0 & 0 \\
\hline & - & & & - & & - & - & - & - & 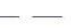 & & - & - - & & & — & & & & & $-x_{1}$ & & -20 & & - - \\
\hline & TOTAL: & 1,824 & 64 & 1,601 & 103 & 1,768 & 471 & 115 & 241 & 67 & 423 & 2,657 & 127 & 2,386 & 105 & 2,618 & 485 & 204 & 316 & 108 & 628 & & & & \\
\hline \multirow{2}{*}{$16: 00-18: 00$} & CAR & 2,333 & 79 & 2,111 & 151 & 2,341 & 668 & 114 & 412 & 54 & 580 & 1,889 & 105 & 1,706 & 105 & 1,916 & 599 & 129 & 415 & 108 & 652 & N & 292 & 1 & 0 \\
\hline & TRK & 35 & 1 & 34 & 2 & 37 & 6 & 0 & 4 & 2 & 6 & 31 & 0 & 26 & 0 & 26 & 1 & 3 & 0 & 1 & 4 & s & 255 & 3 & 0 \\
\hline \multirow[t]{2}{*}{2 HR PM } & BUS & 38 & 0 & 38 & 1 & 39 & 1 & 0 & 0 & 0 & 0 & 44 & 0 & 44 & 0 & 44 & 0 & 0 & 0 & 0 & 0 & E & 912 & 0 & 0 \\
\hline & TTAL - & 2406 & 80 & 2183 & 154 & 2417 & 675 & 114 & 416 & 56 & 586 & 1964 & 105 & 1776 & 105 & 1986 & 600 & 132 & 415 & 109 & 656 & & & & \\
\hline \multirow{2}{*}{$07: 30-18: 00$} & CAR & 7,956 & 246 & 7,101 & 371 & 7,718 & 1,764 & 433 & 960 & 235 & 1,628 & 8,607 & 433 & 7,827 & 368 & 8,628 & 1,670 & 545 & 1,056 & 422 & 2,023 & $\mathrm{~N}$ & 1,079 & 10 & 0 \\
\hline & TRK & 218 & 10 & 205 & 6 & 221 & 23 & 8 & 6 & 11 & 25 & 241 & 11 & 218 & 3 & 232 & 24 & 12 & 11 & 5 & 28 & $\mathrm{~s}$ & 642 & 8 & 0 \\
\hline \multirow[t]{2}{*}{8 HR SUM } & BUS & 117 & 0 & 116 & 2 & 118 & 3 & 1 & 1 & 0 & 2 & 122 & 0 & 122 & 1 & 123 & 1 & 0 & 0 & 0 & 0 & & $\begin{array}{l}2,283 \\
1,160\end{array}$ & $\begin{array}{l}1 \\
2\end{array}$ & $\begin{array}{l}0 \\
0\end{array}$ \\
\hline & TOTAL: & 8,291 & 256 & 7,422 & 379 & 8,057 & 1,790 & 442 & 967 & 246 & 1,655 & 8,970 & 444 & 8,167 & 372 & 8,983 & 1,695 & 557 & 1,067 & 427 & 2,051 & & & & \\
\hline
\end{tabular}

Total 8 Hour Vehicle Volume: 20,746

Total 8 Hour Bicycle Volume: 21

Total 8 Hour Intersection Volume: 20,767

Comment: 
Turning Movement Count Summary Report

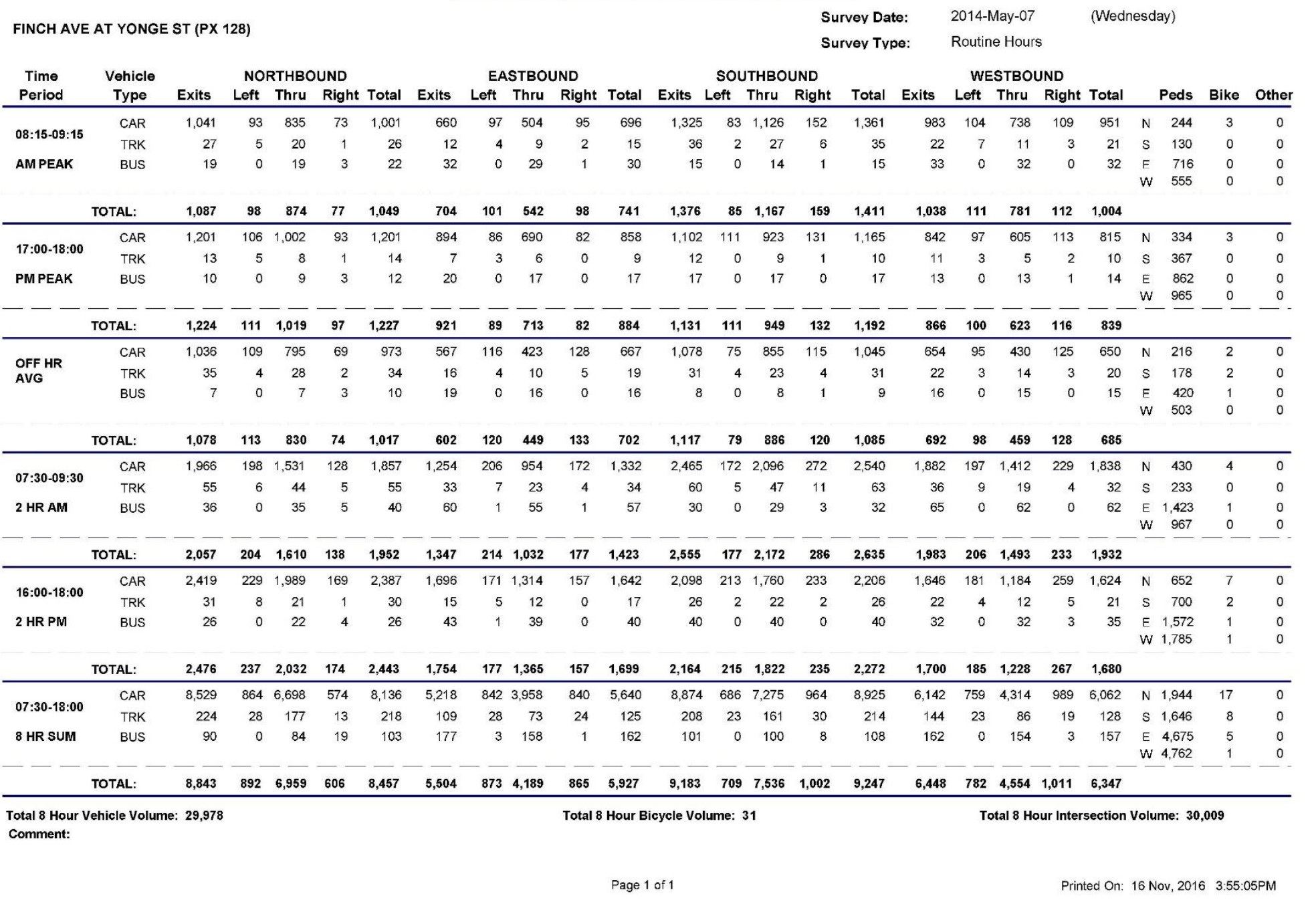


Turning Movement Count Summary Report

\begin{tabular}{|c|c|c|c|c|c|c|c|c|c|c|c|c|c|c|c|c|c|c|c|c|c|c|c|c|c|}
\hline \multirow{3}{*}{$\begin{array}{l}\text { ELMWOOD } \\
\text { Time } \\
\text { Period }\end{array}$} & \multirow{3}{*}{$\begin{array}{c}\text { Vehicle } \\
\text { Type }\end{array}$} & \multirow[b]{3}{*}{ Exits } & \multirow{2}{*}{\multicolumn{3}{|c|}{ NORTHBOUND }} & \multirow[b]{3}{*}{ Total } & \multirow[b]{3}{*}{ Exits } & \multirow{2}{*}{\multicolumn{3}{|c|}{ EASTBOUND }} & \multirow[b]{3}{*}{ Total } & \multirow[b]{3}{*}{ Exits } & \multirow{2}{*}{\multicolumn{3}{|c|}{ SOUTHBOUND }} & \multicolumn{2}{|c|}{$\begin{array}{l}\text { urvey Date: } \\
\text { urvev Type: }\end{array}$} & \multicolumn{3}{|c|}{$\begin{array}{l}\text { 2012-Jul-04 } \\
\text { Routine Hours }\end{array}$} & \multicolumn{2}{|c|}{ (Wednesday) } & \multirow[b]{3}{*}{ eds } & \multirow[b]{3}{*}{ Bike } & \multirow[b]{3}{*}{ Othe } \\
\hline & & & & & & & & & & & & & & & & & & & STBOL & & & & & & \\
\hline & & & Left & Thru & Right & & & Left & Thru & Right & & & Left $T$ & Thru & Right & Total & Exits & Left & Thru & Right & Total & & & & \\
\hline \multirow{3}{*}{$\begin{array}{l}\text { 08:00-09:00 } \\
\text { AM PEAK }\end{array}$} & CAR & 1,247 & 165 & 1,058 & 31 & 1,254 & 148 & 79 & 40 & 36 & 155 & 1,774 & 77 & 1,608 & 48 & 1,733 & 254 & 130 & 41 & 110 & 281 & $\mathrm{~N}$ & 107 & 0 & 0 \\
\hline & TRK & 56 & 1 & 49 & 0 & 50 & 0 & 7 & 0 & 5 & 12 & 69 & 0 & 64 & 0 & 64 & 1 & 0 & 0 & 0 & 0 & s & 162 & 0 & 0 \\
\hline & BUS & 29 & 0 & 29 & 0 & 29 & 0 & 0 & 0 & 0 & 0 & 13 & 0 & 13 & 0 & 13 & 0 & 0 & 0 & 0 & 0 & E & 146 & 0 & 0 \\
\hline \multicolumn{2}{|r|}{ TOTAL: } & 1,332 & 166 & 1,136 & 31 & 1,333 & 148 & 86 & 40 & 41 & 167 & 1,856 & 77 & 1,685 & 48 & 1,810 & 255 & 130 & 41 & 110 & 281 & & & & \\
\hline \multirow{4}{*}{$\begin{array}{l}\text { 16:45-17:45 } \\
\text { PM PEAK }\end{array}$} & CAR & 1,625 & 71 & 1,301 & 127 & 1,499 & 361 & 170 & 99 & 185 & 454 & 1,186 & 135 & 826 & 82 & 1,043 & 415 & 175 & 262 & 154 & 591 & $\mathrm{~N}$ & 141 & 0 & 0 \\
\hline & TRK & 64 & 1 & 61 & 0 & 62 & 2 & 2 & 2 & 2 & 6 & 61 & 0 & 59 & 0 & 59 & 10 & 0 & 9 & 1 & 10 & $s$ & 286 & 0 & 0 \\
\hline & BUS & 43 & 0 & 43 & 0 & 43 & 0 & 0 & 0 & 0 & 0 & 30 & 0 & 30 & 0 & 30 & 0 & 0 & 0 & 0 & 0 & E & 232 & 0 & 0 \\
\hline & TOTAL: & 1,732 & 72 & 1,405 & 127 & 1,604 & 363 & 172 & 101 & 187 & 460 & 1,277 & 135 & 915 & 82 & 1,132 & 425 & 175 & 271 & 155 & 601 & & & & \\
\hline \multirow{4}{*}{$\begin{array}{l}\text { OFF HR } \\
\text { AVG }\end{array}$} & CAR & 1,375 & 131 & 1,214 & 44 & 1,389 & 160 & 69 & 39 & 71 & 179 & 1,051 & 77 & 843 & 65 & 985 & 333 & 137 & 137 & 92 & 366 & $\mathrm{~N}$ & 139 & 0 & 0 \\
\hline & TRK & 71 & 2 & 70 & 1 & 73 & 2 & 1 & 1 & 1 & 3 & 57 & 0 & 56 & 0 & 56 & 2 & 0 & 0 & 0 & 0 & s & 206 & 0 & 0 \\
\hline & BUS & 19 & 0 & 19 & 0 & 19 & 0 & 0 & 0 & 0 & 0 & 18 & 0 & 18 & 0 & 18 & 0 & 0 & 0 & 0 & 0 & $\begin{array}{l}E \\
W\end{array}$ & $\begin{array}{l}246 \\
451\end{array}$ & $\begin{array}{l}0 \\
0\end{array}$ & $\begin{array}{l}0 \\
0\end{array}$ \\
\hline & TOTAL: & 1,465 & 133 & 1,303 & 45 & 1,481 & 162 & 70 & 40 & 72 & 182 & 1,126 & 77 & 917 & 65 & 1,059 & 335 & 137 & 137 & 92 & 366 & & & & \\
\hline \multirow{2}{*}{$07: 30-09: 30$} & CAR & 2,502 & 311 & 2,114 & 60 & 2,485 & 250 & 153 & 79 & 70 & 302 & 3,394 & $4 \quad 111$ & 3,065 & 70 & 3,246 & 493 & 259 & 112 & 235 & 606 & $\mathrm{~N}$ & 175 & 0 & 0 \\
\hline & TRK & 114 & 2 & 103 & 1 & 106 & 2 & 11 & 1 & 13 & 25 & 130 & 0 & 117 & 0 & 117 & 2 & 0 & 0 & 0 & 0 & $s$ & 329 & 0 & 0 \\
\hline \multirow[t]{3}{*}{2 HR AM } & Bus & 60 & 0 & 60 & 0 & 60 & 0 & 0 & 0 & 0 & 0 & 31 & 0 & 31 & 0 & 31 & 0 & 0 & 0 & 0 & 0 & E & 287 & 0 & 0 \\
\hline & & - & -1 & C & 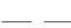 & - & - & 工 & - & $\ldots$ & & & - & - & & - & & & & & & w & 961 & 0 & 0 \\
\hline & TOTAL: & 2,676 & 313 & 2,277 & 61 & 2,651 & 252 & 164 & 80 & 83 & 327 & 3,555 & 111 & 3,213 & 70 & 3,394 & 495 & 259 & 112 & 235 & 606 & & & & \\
\hline $16-00-18 \cdot 00$ & CAR & 3,126 & 120 & 2,525 & 217 & 2,862 & 697 & 293 & 196 & 331 & 820 & 2,301 & 284 & 1,654 & 164 & 2,102 & 718 & 316 & 434 & 308 & 1,058 & $\mathrm{~N}$ & 315 & 0 & 0 \\
\hline 16:00-18:00 & TRK & 116 & 2 & 106 & 1 & 109 & 3 & 6 & 2 & 5 & 13 & 120 & 0 & 114 & 0 & 114 & 16 & 1 & 14 & 4 & 19 & $s$ & 544 & 0 & 0 \\
\hline $2 \mathrm{HR}$ PM & BUS & 85 & 0 & 82 & 0 & 82 & 0 & 0 & 0 & 0 & 0 & 57 & 0 & 57 & 0 & 57 & 0 & 0 & 0 & 3 & 3 & E & 455 & 0 & 0 \\
\hline & TOTAL: & 3,327 & 122 & 2,713 & 218 & 3,053 & 700 & 299 & 198 & 336 & 833 & 2,478 & 284 & 1,825 & 164 & 2,273 & 734 & 317 & 448 & 315 & 1,080 & & & & \\
\hline $07 \cdot 30-18.00$ & CAR & 11,128 & 953 & 9,496 & 451 & 10,900 & 1,583 & 721 & 430 & 686 & 1,837 & 9,901 & 702 & 8,091 & 494 & 9,287 & 2,539 & 1,124 & 1,092 & 911 & 3,127 & $\mathrm{~N}$ & 1,047 & 0 & 0 \\
\hline $07: 30-18: 00$ & TRK & 515 & 10 & 490 & 5 & 505 & 10 & 21 & 5 & 22 & 48 & 476 & 0 & 453 & 0 & 453 & 24 & 1 & 14 & 4 & 19 & s 1 & 1,697 & 0 & 0 \\
\hline 8 HR SUM & BUS & 220 & 0 & 217 & 0 & 217 & 0 & 0 & 0 & 0 & 0 & 159 & 0 & 159 & 0 & 159 & 0 & 0 & 0 & 3 & 3 & & $\begin{array}{l}1,726 \\
4,002\end{array}$ & $\begin{array}{l}0 \\
0\end{array}$ & $\begin{array}{l}0 \\
0\end{array}$ \\
\hline & TOTAL: & 11,863 & 963 & 10,203 & 456 & 11,622 & 1,593 & 742 & 435 & 708 & 1,885 & 10,536 & 702 & 8,703 & 494 & 9,899 & 2,563 & 1,125 & 1,106 & 918 & 3,149 & & & & \\
\hline $\begin{array}{l}\text { Total } 8 \text { Hour V } \\
\text { Comment: }\end{array}$ & ehicle Volun & 26,555 & & & & & & & & Total 8 & 3 Hour B & icycle Volu & lume: 0 & & & & & & tal $8 \mathrm{Ho}$ & jur Inters & rsection 1 & Volum & me: 26, & & \\
\hline
\end{tabular}


Turning Movement Count Summary Report

ELMHURST AVE AT GREENFIELD AVE \& YONGE ST (PX 1100)

Survey Date:

2016-May-18

(Wednesday)

Time Vehicle

Survey Type: Routine Hours

\begin{tabular}{|c|c|c|c|c|c|c|c|c|c|c|c|c|c|c|c|c|c|c|c|c|c|c|c|c|c|}
\hline \multirow{2}{*}{$\begin{array}{l}\text { IIme } \\
\text { Period }\end{array}$} & \multirow{2}{*}{$\begin{array}{c}\text { Venicle } \\
\text { Type }\end{array}$} & \multicolumn{5}{|c|}{ NURITLUUND } & \multicolumn{5}{|c|}{ EADIDUUIVD } & \multicolumn{5}{|c|}{ SOUIREUUINL } & & \multirow{2}{*}{\multicolumn{2}{|c|}{ Peds }} & \multirow[b]{2}{*}{ Bike } & \multirow[b]{2}{*}{ Other } \\
\hline & & Exits & Left & Thru & Right & Total & Exits & Left & Thru & Right & Total & Exits & Left & Thru & Right & Total & Exits & Left & Thru & Right & Total & & & & \\
\hline \multirow{2}{*}{ 07:30-08:30 } & CAR & 930 & 64 & 831 & 153 & 1,048 & 276 & 24 & 81 & 34 & 139 & 1,010 & 42 & 749 & 65 & 856 & 223 & 227 & 94 & 75 & 396 & $\mathrm{~N}$ & 259 & 0 & 0 \\
\hline & TRK & 18 & 0 & 14 & 4 & 18 & 6 & 0 & 2 & 0 & 2 & 28 & 0 & 25 & 1 & 26 & 2 & 3 & 1 & 4 & 8 & $s$ & 179 & 0 & 0 \\
\hline \multirow[t]{3}{*}{ AM PEAK } & BUS & 19 & 0 & 19 & 1 & 20 & 1 & 0 & 0 & 0 & 0 & 18 & 0 & 18 & 0 & 18 & 0 & 0 & 0 & 0 & 0 & E & 606 & 0 & 0 \\
\hline & & & & & & & & & & & & & & & & & & & & & & & & & \\
\hline & TOTAL: & 967 & 64 & 864 & 158 & 1,086 & 283 & 24 & 83 & 34 & 141 & 1,056 & 42 & 792 & 66 & 900 & 225 & 230 & 95 & 79 & 404 & & & & \\
\hline \multirow{2}{*}{ 16:00-17:00 } & CAR & 1,158 & 28 & 1,063 & 69 & 1,160 & 202 & 41 & 86 & 66 & 193 & 1,129 & 47 & 850 & 54 & 951 & 164 & 213 & 82 & 54 & 349 & $\mathrm{~N}$ & 345 & 5 & 0 \\
\hline & TRK & 16 & 0 & 12 & 2 & 14 & 3 & 1 & 0 & 0 & 1 & 14 & 1 & 13 & 1 & 15 & 1 & 1 & 0 & 3 & 4 & s & 367 & 2 & 0 \\
\hline \multirow{3}{*}{$\begin{array}{l}\text { PM PEAK } \\
-\ldots-\ldots\end{array}$} & BUS & 22 & 0 & 22 & 0 & 22 & 0 & 0 & 0 & 0 & 0 & 23 & 0 & 23 & 0 & 23 & 0 & 0 & 0 & 0 & 0 & E & 805 & 0 & 0 \\
\hline & --- & - & -1 & - & -- & - & - & - & - & - & $-\ldots+c_{2}$ & - & -- & - & - & - & -- & - & -- & - & - & & -520 & & \\
\hline & TOTAL: & 1,196 & 28 & 1,097 & 71 & 1,196 & 205 & 42 & 86 & 66 & 194 & 1,166 & 48 & 886 & 55 & 989 & 165 & 214 & 82 & 57 & 353 & & & & \\
\hline \multirow{5}{*}{$\begin{array}{l}\text { OFF HR } \\
\text { AVG }\end{array}$} & CAR & 1,021 & 47 & 944 & 76 & 1,067 & 139 & 27 & 29 & 69 & 125 & 1,210 & 34 & 995 & 68 & 1,097 & 151 & 146 & 36 & 50 & 232 & $\mathrm{~N}$ & 349 & 2 & 0 \\
\hline & TRK & 34 & 1 & 31 & 5 & 37 & 8 & 1 & 1 & 1 & 3 & 41 & 2 & 37 & 2 & 41 & 4 & 3 & 1 & 2 & 6 & $s$ & 295 & & 0 \\
\hline & BUS & 10 & 0 & 10 & 0 & 10 & 0 & 0 & 0 & 0 & 0 & 13 & 0 & 13 & 0 & 13 & 0 & 0 & 0 & 0 & 0 & E & 670 & & 0 \\
\hline & & & & & & & & & & & & & & & & & & & & & & w & 530 & & 0 \\
\hline & TOTAL: & 1,065 & 48 & 985 & 81 & 1,114 & 147 & 28 & 30 & 70 & 128 & 1,264 & 36 & 1,045 & 70 & 1,151 & 155 & 149 & 37 & 52 & 238 & & & & \\
\hline \multirow{2}{*}{ 07:30-09:30 } & CAR & 1,897 & 134 & 1,718 & 258 & 2,110 & 512 & 49 & 172 & 80 & 301 & 1,868 & 82 & 1,375 & 133 & 1,590 & 433 & 413 & 166 & 130 & 709 & $\mathrm{~N}$ & 505 & 0 & 0 \\
\hline & TRK & 48 & 1 & 42 & 7 & 50 & 9 & 0 & 2 & 1 & 3 & 56 & 0 & 51 & 5 & 56 & 9 & 4 & 3 & 6 & 13 & $s$ & 359 & 1 & 0 \\
\hline \multirow[t]{3}{*}{2 HR AM } & BUS & 38 & 0 & 38 & 1 & 39 & 1 & 0 & 0 & 0 & 0 & 33 & 0 & 33 & 0 & 33 & 0 & 0 & 0 & 0 & 0 & E & 1,080 & & 0 \\
\hline & & - & -- & - & $\ldots$ & - & - & $\ldots$ & - & - & - & 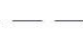 & $-1-1$ & - & & - & 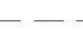 & - & 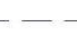 & 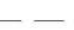 & - - & $-w$ & 1 & 2 & 0 \\
\hline & TOTAL: & 1,983 & 135 & 1,798 & 266 & 2,199 & 522 & 49 & 174 & 81 & 304 & 1,957 & 82 & 1,459 & 138 & 1,679 & 442 & 417 & 169 & 136 & 722 & & & & \\
\hline \multirow{2}{*}{ 16:00-18:00 } & CAR & 2,376 & 65 & 2,205 & 141 & 2,411 & 384 & 72 & 160 & 122 & 354 & 1,906 & 83 & 1,347 & 105 & 1,535 & 353 & 437 & 183 & 99 & 719 & $\mathrm{~N}$ & 706 & 8 & 0 \\
\hline & TRK & 32 & 0 & 28 & 2 & 30 & 6 & 1 & 1 & 0 & 2 & 25 & 3 & 22 & 1 & 26 & 1 & 3 & 0 & 3 & 6 & $s$ & 653 & 3 & 0 \\
\hline \multirow[t]{2}{*}{2 HR PM } & BUS & 36 & 0 & 36 & 0 & 36 & 0 & 0 & 0 & 0 & 0 & 38 & 0 & 38 & 0 & 38 & 0 & 0 & 0 & 0 & 0 & E & 1,788 & & 0 \\
\hline & TOTAI. & & & & & & & & & & & & & 1407 & & 1590 & & & & & 705 & & & & \\
\hline \multirow{2}{*}{$07: 30-18: 00$} & CAR & 8,359 & 388 & 7,700 & 701 & 8,789 & 1,447 & 230 & 446 & 477 & 1,153 & 8,613 & 300 & 6,703 & 509 & 7,512 & 1,389 & 1,433 & 492 & 429 & 2,354 & $\mathrm{~N}$ & 2,607 & 15 & 0 \\
\hline & TRR & 214 & 3 & 195 & 27 & 225 & 42 & 3 & 6 & 6 & 15 & 242 & 9 & 219 & 15 & 243 & 25 & 17 & 7 & 16 & 40 & $s$ & 2,191 & 6 & 0 \\
\hline \multirow[t]{3}{*}{8 HR SUM } & BUS & 116 & 0 & 115 & 1 & 116 & 2 & 1 & 1 & 0 & 2 & 122 & 0 & 122 & 0 & 122 & 0 & 0 & 0 & 0 & 0 & & & & 0 \\
\hline & & & & & & & & & & & & & & & & & & & & & & & $-0,00$ & & \\
\hline & TOTAL: & 8,689 & 391 & 8,010 & 729 & 9,130 & 1,491 & 234 & 453 & 483 & 1,170 & 8,977 & 309 & 7,044 & 524 & 7,877 & 1,414 & 1,450 & 499 & 445 & 2,394 & & & & \\
\hline
\end{tabular}

Total 8 Hour Vehicle Volume: 20,571

Total 8 Hour Bicycle Volume: 28

Total 8 Hour Intersection Volume: $\mathbf{2 0 , 5 9 9}$

Comment:

Page 1 of 1

Printed On: 16 Nov, 2016 4:09:55PM 


\section{[II TORONTO}

City of Toronto - Traffic Safety Unit

Turning Movement Count Summary Report

KEMPFORD BLVD AT YONGE ST (PX 1101)

Survey Date:

2014-Apr-14

(Monday)

Time Vehicle

Survey Type: Routine Hours

\begin{tabular}{|c|c|c|c|c|c|c|c|c|c|c|c|c|c|c|c|c|c|c|c|c|c|c|c|c|c|}
\hline \multirow{2}{*}{ Period } & \multirow[b]{2}{*}{ Type } & \multirow[b]{2}{*}{ Exits } & & \multirow[b]{2}{*}{ Exits } & & & & \multirow{2}{*}{\multicolumn{2}{|c|}{ Peds }} & \multirow{3}{*}{$\frac{\text { Bike }}{3}$} & \multirow[b]{2}{*}{ Other } \\
\hline & & & Left & Thru & Right & Total & & Left & Thru & Right & Total & Exits & Left & Thru & Right & Total & Exits & Left & Thru & Right & Total & & & & \\
\hline \multirow{2}{*}{ 08:00-09:00 } & CAR & 991 & 57 & 953 & 0 & 1,010 & 0 & 38 & 0 & 32 & 70 & 1,191 & c & 1,159 & 76 & 1,235 & 133 & 0 & 0 & 0 & 0 & $\mathrm{~N}$ & 28 & & 0 \\
\hline & TRK & 28 & 1 & 27 & 0 & 28 & 0 & 1 & 0 & 1 & 2 & 27 & 7 & 26 & 1 & 27 & 2 & 0 & 0 & 0 & 0 & $s$ & 25 & 4 & 0 \\
\hline \multirow[t]{2}{*}{ AM PEAK } & BUS & 25 & 0 & 25 & 0 & 25 & 0 & 0 & 0 & 0 & 0 & 25 & 5 & 25 & 2 & 27 & 2 & 0 & 0 & 0 & 0 & E & 0 & 1 & 0 \\
\hline & TOTAL: & 1,044 & 58 & 1,005 & 0 & 1,063 & 0 & 39 & 0 & 33 & 72 & 1,243 & 3 & $\begin{array}{ll}0 & 1,210\end{array}$ & 79 & 1,289 & 137 & 0 & 0 & 0 & 0 & & & & \\
\hline \multirow{2}{*}{ 17:00-18:00 } & CAR & 1,315 & 53 & 1,281 & 0 & 1,334 & 0 & 34 & 0 & 39 & 73 & 920 & 0 & 881 & 55 & 936 & 108 & 0 & 0 & 0 & 0 & $\mathrm{~N}$ & 88 & 2 & 0 \\
\hline & TRK & 11 & 1 & 11 & 0 & 12 & 0 & 0 & 0 & 1 & 1 & 7 & 7 & 6 & 0 & 6 & 1 & 0 & 0 & 0 & 0 & $s$ & 71 & 2 & 0 \\
\hline \multirow[t]{3}{*}{ PM PEAK } & BUS & 13 & 0 & 13 & 0 & 13 & 0 & 0 & 0 & 0 & 0 & 18 & c & 18 & 0 & 18 & 0 & 0 & 0 & 0 & 0 & E & 0 & 0 & 0 \\
\hline & - & - & -- & - & $\ldots$ & - - & _ & 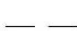 & $\ldots$ & - & 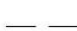 & 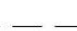 & - & - & - & - & - & _ & $-\ldots$ & - & 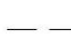 & w & -200 & 0 & 0 \\
\hline & TOTAL: & 1,339 & 54 & 1,305 & 0 & 1,359 & 0 & 34 & 0 & 40 & 74 & 945 & 5 & 905 & 55 & 960 & 109 & 0 & 0 & 0 & 0 & & & & \\
\hline \multirow{5}{*}{$\begin{array}{l}\text { OFF HR } \\
\text { AVG }\end{array}$} & CAR & 1,000 & 36 & 972 & 0 & 1,008 & 1 & 28 & 1 & 36 & 65 & 950 & 0 & 914 & 46 & 960 & 82 & 0 & 0 & 0 & 0 & $\mathrm{~N}$ & 43 & 1 & 0 \\
\hline & TRK & 33 & 0 & 33 & 0 & 33 & 0 & 0 & 0 & 0 & 0 & 31 & 1 & 31 & 0 & 31 & 0 & 0 & 0 & 0 & 0 & $s$ & 35 & 2 & 0 \\
\hline & BUS & 9 & 0 & 9 & 1 & 10 & 1 & 0 & 0 & 0 & 0 & 11 & c & 11 & 0 & 11 & 0 & 0 & 0 & 0 & 0 & E & 0 & & 0 \\
\hline & & & & & & & & & & & & & & & & & & & & & & & & & \\
\hline & TOTAL: & 1,042 & 36 & 1,014 & 1 & 1,051 & 2 & 28 & 1 & 36 & 65 & 992 & 2 & 956 & 46 & 1,002 & 82 & 0 & 0 & 0 & 0 & & & & \\
\hline \multirow{2}{*}{$07: 30-09: 30$} & CAR & 1,868 & 94 & 1,797 & 0 & 1,891 & 0 & 71 & 0 & 70 & 141 & 2,233 & 3 & $0 \quad 2,163$ & 126 & 2,289 & 220 & 0 & 0 & 0 & 0 & $\mathrm{~N}$ & 66 & 6 & 0 \\
\hline & TRK & 54 & 5 & 53 & 0 & 58 & 0 & 1 & 0 & 2 & 3 & 59 & 9 & $\begin{array}{l}0 \quad 57 \\
0\end{array}$ & 1 & 58 & 6 & 0 & 0 & 0 & 0 & $s$ & 49 & 6 & 0 \\
\hline \multirow{3}{*}{2 HR AM } & BUS & 48 & 1 & 47 & 0 & 48 & 0 & 1 & 0 & 0 & 1 & 44 & 4 & 44 & 3 & 47 & 4 & 0 & 0 & 0 & 0 & E & 0 & 2 & 0 \\
\hline & & & & - & & - & - & - & $\ldots$ & 一 & - & -- & - & -- & & - & - & - & $\ldots-1$ & - & - & $w$ & 249 & 0 & \\
\hline & TOTAL: & 1,970 & 100 & 1,897 & 0 & 1,997 & 0 & 73 & 0 & 72 & 145 & 2,336 & & $\begin{array}{ll}0 & 2,264 \\
\end{array}$ & 130 & 2,394 & 230 & 0 & 0 & 0 & 0 & & & & \\
\hline \multirow{2}{*}{$16: 00-18: 00$} & CAR & 2,564 & 103 & 2,493 & 0 & 2,596 & 0 & 71 & 0 & 83 & 154 & 1,757 & 7 & $\begin{array}{l}0 \quad 1,674 \\
\end{array}$ & 116 & 1,790 & 219 & 0 & 0 & 0 & 0 & $\mathrm{~N}$ & 152 & 4 & 0 \\
\hline & TRK & 25 & 1 & 25 & 0 & 26 & 0 & 0 & 0 & 2 & 2 & 14 & 4 & $0 \quad 12$ & 1 & 13 & 2 & 0 & 0 & 0 & 0 & $s$ & 120 & 3 & 0 \\
\hline \multirow[t]{3}{*}{2 HR PM } & BUS & 29 & 0 & 29 & 0 & 29 & 0 & 0 & 0 & 0 & 0 & 41 & c & 41 & 1 & 42 & 1 & 0 & 0 & 0 & 0 & E & 0 & 0 & 0 \\
\hline & & & & & & & & & & & & & & & & & & & & & & w & 374 & 0 & 0 \\
\hline & TOTAL: & 2,618 & 104 & 2,547 & 0 & 2,651 & 0 & 71 & 0 & 85 & 156 & 1,812 & 2 & $\begin{array}{ll}0 & 1,727 \\
\end{array}$ & 118 & 1,845 & 222 & 0 & 0 & 0 & 0 & & & & \\
\hline \multirow{2}{*}{$07: 30-18: 00$} & CAR & 8,434 & 339 & 8,179 & 0 & 8,518 & 2 & 255 & 2 & 295 & 552 & 7,786 & 6 & $\begin{array}{l}0 \\
7,491\end{array}$ & 426 & 7,917 & 765 & 0 & 0 & 0 & 0 & $\mathrm{~N}$ & 390 & 13 & 0 \\
\hline & TRK & 213 & 7 & 211 & 0 & 218 & 0 & 2 & 0 & 5 & 7 & 197 & c & $\begin{array}{l}0 \quad 192 \\
\end{array}$ & 3 & 195 & 10 & 0 & 0 & 0 & 0 & $s$ & 308 & 15 & 0 \\
\hline 8 HR SUM & BUS & 111 & 1 & 110 & 2 & 113 & 2 & 1 & 0 & 0 & 1 & 129 & 9 & 129 & 4 & 133 & 5 & 0 & 0 & 0 & 0 & $\stackrel{E}{W}$ & $\begin{array}{r}0 \\
1,095\end{array}$ & $\begin{array}{l}5 \\
0\end{array}$ & $\begin{array}{l}0 \\
0\end{array}$ \\
\hline & TOTAL: & 8,758 & 347 & 8,500 & 2 & 8,849 & 4 & 258 & 2 & 300 & 560 & 8,112 & 8 & 0 & 433 & 8,245 & 780 & 0 & 0 & 0 & 0 & & & & \\
\hline
\end{tabular}

Total 8 Hour Vehicle Volume: 17,654

Total 8 Hour Bicycle Volume: 33

Total 8 Hour Intersection Volume: $\mathbf{1 7 , 6 8 7}$

Comment: 
Turning Movement Count Summary Report

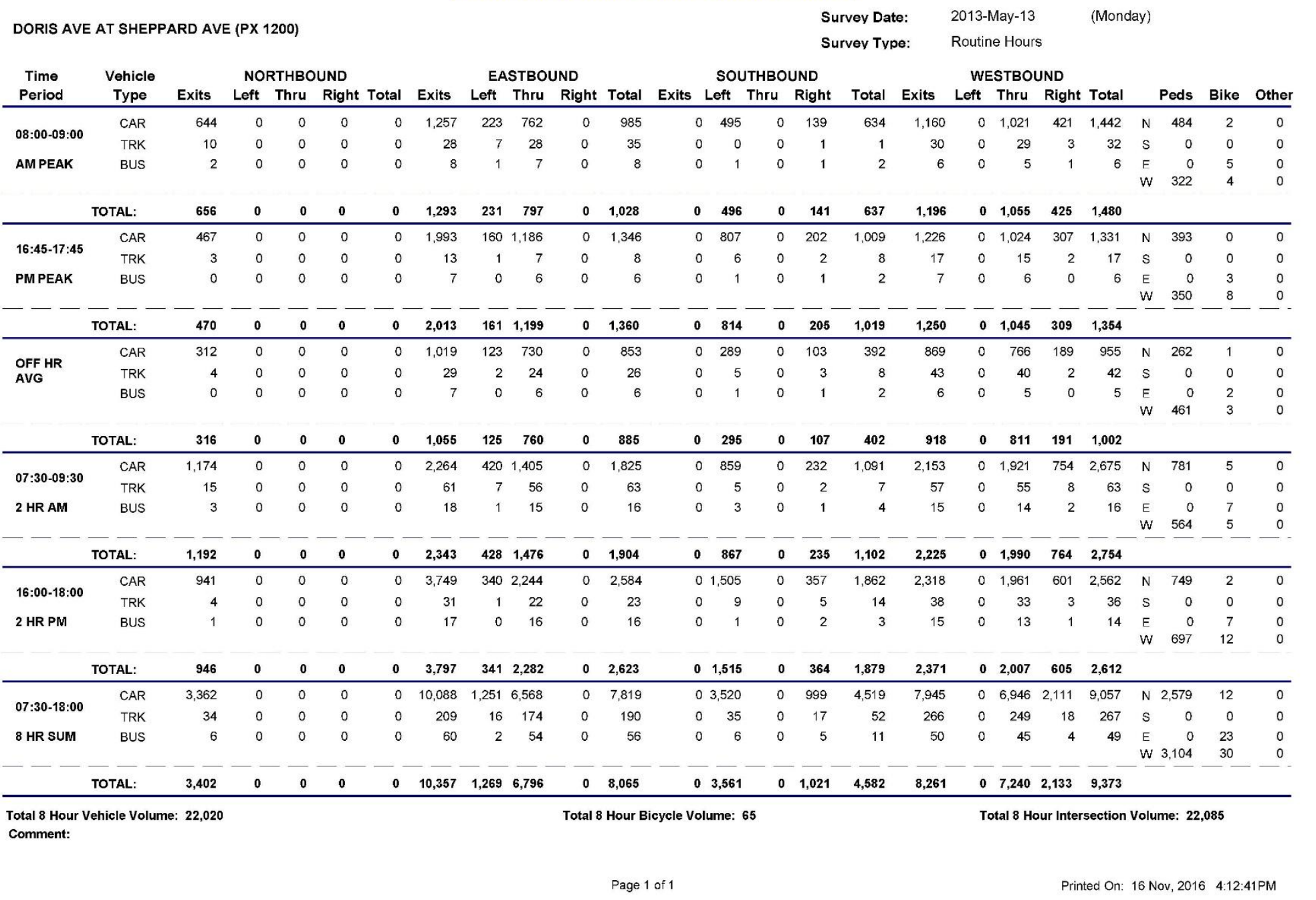


Turning Movement Count Summary Report

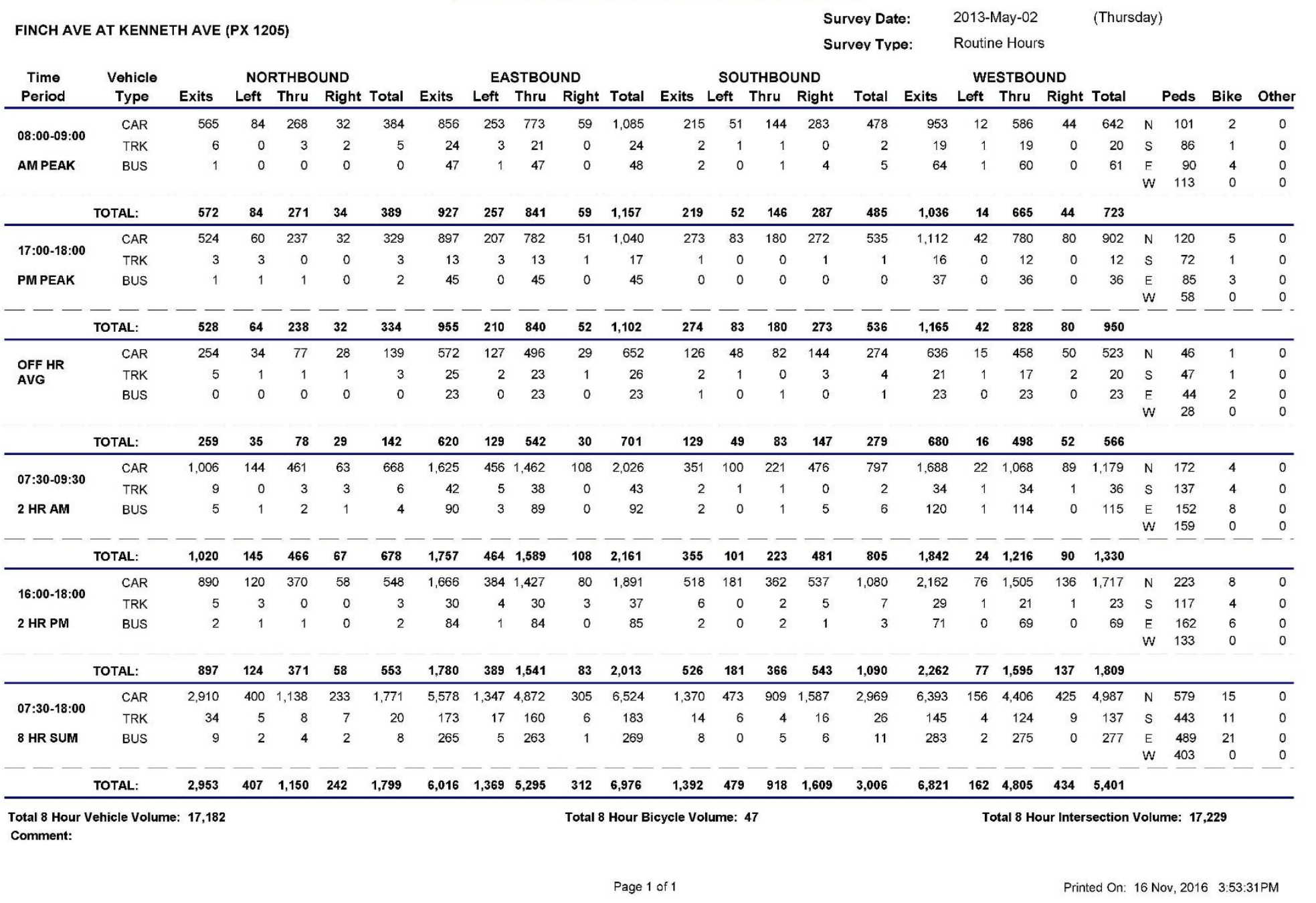


Turning Movement Count Summary Report

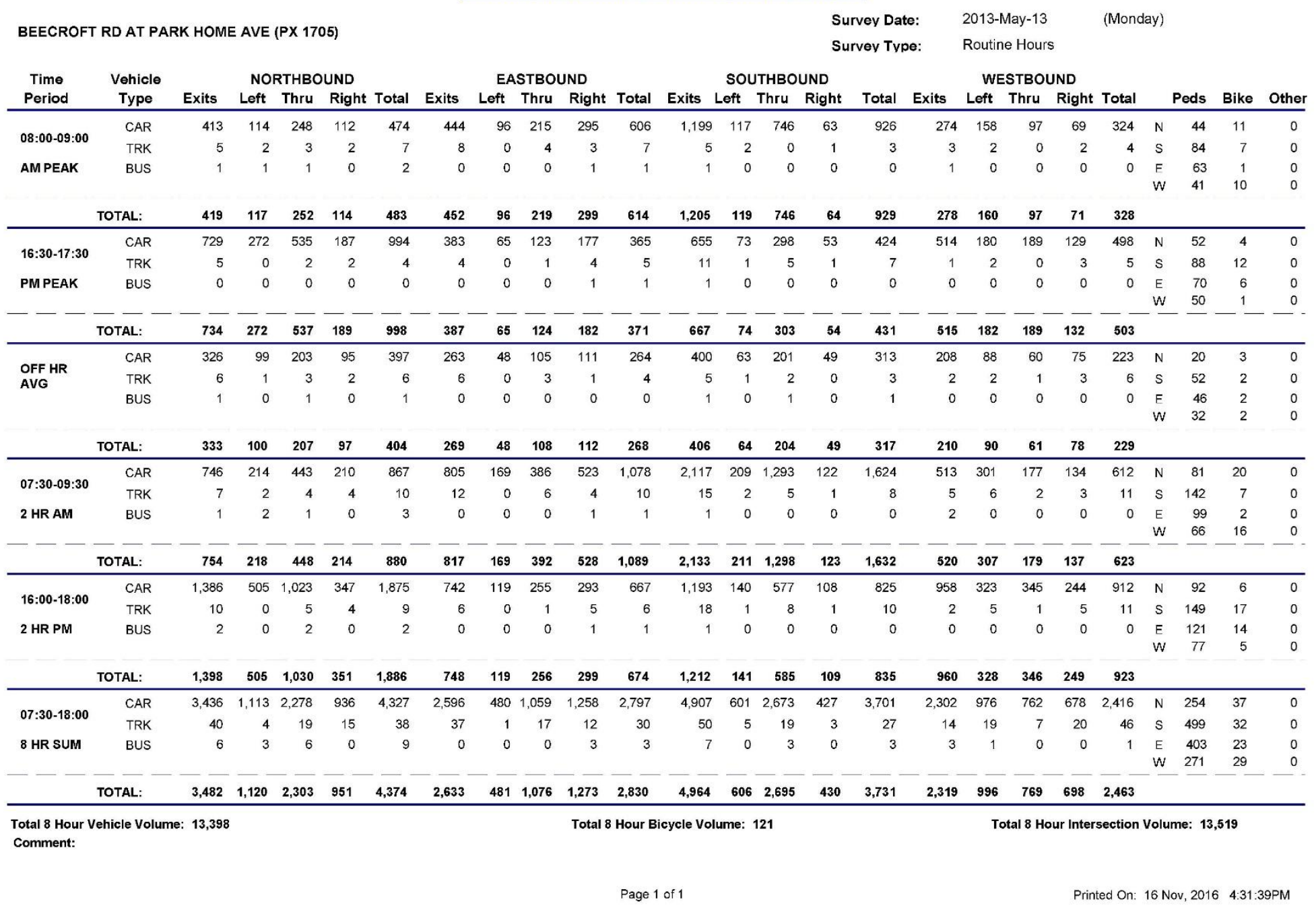




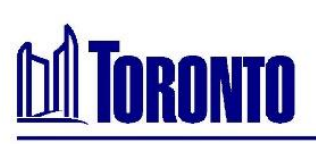

\section{City of Toronto - Traffic Safety Unit}

Turning Movement Count Summary Report

DORIS AVE AT GREENFIELD AVE (PX 1751)

Survey Date:

Survey Type:

2013-May-13

Routine Hours

(Monday)

\begin{tabular}{|c|c|c|c|c|c|c|c|c|c|c|c|c|c|c|c|c|c|c|c|c|c|c|c|c|c|}
\hline \multirow{2}{*}{$\begin{array}{l}\text { Time } \\
\text { Period }\end{array}$} & \multirow{2}{*}{$\begin{array}{c}\text { Vehicle } \\
\text { Type } \\
\end{array}$} & \multirow[b]{2}{*}{ Exits } & \multicolumn{3}{|c|}{ NORTHBOUND } & \multirow[b]{2}{*}{ Total } & \multicolumn{5}{|c|}{ EASTBOUND } & \multicolumn{5}{|c|}{ SOUTHBOUND } & \multicolumn{5}{|c|}{ WESTBOUND } & \multirow{2}{*}{\multicolumn{2}{|c|}{ Peds }} & \multirow[b]{2}{*}{ Bike } & \multirow[b]{2}{*}{ Other } \\
\hline & & & Left & Thru & Right & & Exits & Left & Thru & Right & Total & Exits & Left & Thru & Right & Total & Exits & Left & Thru & Right & Total & & & & \\
\hline \multirow{2}{*}{ 08:00-09:00 } & CAR & 417 & 125 & 337 & 22 & 484 & 142 & 78 & 59 & 277 & 414 & 875 & 61 & 595 & 240 & 896 & 371 & 3 & 6 & 2 & 11 & $\mathrm{~N}$ & 60 & 1 & 0 \\
\hline & TRK & 5 & 0 & 2 & 0 & 2 & 1 & 3 & 1 & 2 & 6 & 3 & 0 & 1 & 0 & 1 & 0 & 0 & 0 & 0 & 0 & $s$ & 206 & 1 & 0 \\
\hline \multirow[t]{2}{*}{ AM PEAK } & BUS & 0 & 0 & 0 & 0 & 0 & 0 & 0 & 0 & 0 & 0 & 1 & 0 & 1 & 0 & 1 & 0 & 0 & 0 & 0 & 0 & E & 66 & 0 & 0 \\
\hline & TOTAL: & 422 & 125 & 339 & 22 & 486 & 143 & 81 & 60 & 279 & 420 & 879 & 61 & 597 & 240 & 898 & 371 & 3 & 6 & 2 & 11 & & & & \\
\hline \multirow{2}{*}{ 16:30-17:30 } & CAR & 633 & 55 & 358 & 14 & 427 & 35 & 194 & 12 & 261 & 467 & 852 & 9 & 527 & 216 & 752 & 319 & 64 & 48 & 81 & 193 & $\mathrm{~N}$ & 25 & 0 & 0 \\
\hline & TRK & 2 & 0 & 2 & 0 & 2 & 0 & 0 & 0 & 0 & 0 & 2 & 0 & 2 & 0 & 2 & 0 & 0 & 0 & 0 & 0 & s & 29 & 4 & 0 \\
\hline \multirow[t]{3}{*}{ PM PEAK } & BUS & 0 & 0 & 0 & 0 & 0 & 0 & 0 & 0 & 0 & 0 & 1 & 0 & 1 & 0 & 1 & 0 & 0 & 0 & 0 & 0 & E & 41 & 0 & 0 \\
\hline & - & & & - & & - & 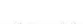 & & 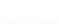 & 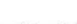 & & & & & & 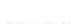 & 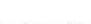 & & & & & w & 132 & 1 & 0 \\
\hline & TOTAL: & 635 & 55 & 360 & 14 & 429 & 35 & 194 & 12 & 261 & 467 & 855 & 9 & 530 & 216 & 755 & 319 & 64 & 48 & 81 & 193 & & & & \\
\hline \multirow{3}{*}{$\begin{array}{l}\text { OFF HR } \\
\text { AVG }\end{array}$} & CAR & 301 & 46 & 229 & 12 & 287 & 29 & 68 & 13 & 116 & 197 & 436 & 4 & 312 & 111 & 427 & 165 & 8 & 8 & 4 & 20 & $\mathrm{~N}$ & 47 & 1 & 0 \\
\hline & TRK & 2 & 1 & 2 & 0 & 3 & 1 & 0 & 0 & 2 & 2 & 7 & 1 & 5 & 3 & 9 & 4 & 0 & 0 & 0 & 0 & s & 201 & 0 & 0 \\
\hline & BUS & 0 & 0 & 0 & 0 & 0 & 0 & 0 & 0 & 0 & 0 & 0 & 0 & 0 & 0 & 0 & 0 & 0 & 0 & 0 & 0 & E & 48 & 0 & 0 \\
\hline \multirow{2}{*}{\multicolumn{2}{|c|}{ TOTAL: }} & & & & & & & & & & & & & & & & & & & & & & & & \\
\hline & & & & & & & & & & & & & & & & & & & & & & & & & \\
\hline \multirow{2}{*}{ 07:30-09:30 } & CAR & 743 & 202 & 594 & 44 & 840 & 255 & 144 & 117 & 436 & 697 & 1,448 & 94 & 1,005 & 408 & 1,507 & 628 & 7 & 18 & 5 & 30 & $\mathrm{~N}$ & 78 & 2 & 0 \\
\hline & TRK & 7 & 0 & 4 & 2 & 6 & 3 & 3 & 1 & 2 & 6 & 5 & 0 & 3 & 0 & 3 & 0 & 0 & 0 & c & 0 & s & 227 & 2 & 0 \\
\hline \multirow{3}{*}{2 HR AM } & BUS & 0 & 0 & 0 & 0 & 0 & 0 & 0 & 0 & 0 & 0 & 2 & 0 & 2 & 0 & 2 & 0 & 0 & 0 & 0 & 0 & E & 79 & 0 & 0 \\
\hline & & & & & & & & & & & & & & & & & & & & & & w & 333 & 1 & 0 \\
\hline & TOTAL: & 750 & 202 & 598 & 46 & 846 & 258 & 147 & 118 & 438 & 703 & 1,455 & 94 & 1,010 & 408 & 1,512 & 628 & 7 & 18 & 5 & 30 & & & & \\
\hline \multirow{2}{*}{ 16:00-18:00 } & CAR & 1,174 & 116 & 677 & 27 & 820 & 68 & 369 & 24 & 510 & 903 & 1,630 & 17 & 1,020 & 384 & 1,421 & 593 & 100 & 93 & 128 & 321 & $\mathrm{~N}$ & 49 & 1 & 0 \\
\hline & TR & 3 & 0 & 3 & 0 & 3 & 0 & 0 & 0 & 1 & 1 & 6 & 0 & 5 & 0 & 5 & 0 & 0 & 0 & 0 & 0 & s & 80 & 5 & 0 \\
\hline \multirow[t]{3}{*}{2 HR PM } & BUS & 0 & 0 & 0 & 0 & 0 & 0 & 0 & 0 & 0 & 0 & 1 & 0 & 1 & 0 & 1 & 0 & 0 & 0 & 0 & 0 & $E$ & 81 & 1 & 0 \\
\hline & & & & & & & & & & & & & & & & & & & & & & & & & \\
\hline & TOTAL: & 1,177 & 116 & 680 & 27 & 823 & 68 & 369 & 24 & 511 & 904 & 1,637 & 17 & 1,026 & 384 & 1,427 & 593 & 100 & 93 & 128 & 321 & & & & \\
\hline & CAR & 3,120 & 503 & 2,187 & 118 & 2,808 & 437 & 784 & 194 & 1,408 & 2,386 & 4,822 & 125 & 3,274 & 1,236 & 4,635 & 1,883 & 140 & 144 & 149 & 433 & $\mathrm{~N}$ & 316 & 5 & 0 \\
\hline 07:30-18:00 & & 17 & 3 & 14 & 2 & 19 & 5 & 3 & 1 & 11 & 15 & 39 & 2 & 27 & 10 & 39 & 13 & 1 & 0 & 0 & 1 & & 1,112 & 8 & 0 \\
\hline 8 HR SUM & Bus & 0 & 0 & 0 & 0 & 0 & 0 & 0 & 0 & 0 & 0 & 4 & 0 & 4 & 0 & 4 & 0 & 0 & 0 & 0 & 0 & & 352 & 2 & 0 \\
\hline & & 137 & 506 & 2.2 & 120 & & 442 & 787 & 195 & 19 & 2,401 & 4.865 & 127 & 3.305 & 1.246 & 4.678 & 1896 & 141 & 144 & 149 & 434 & & & & \\
\hline
\end{tabular}

Total 8 Hour Vehicle Volume: 10,340

Total 8 Hour Bicycle Volume: 19

Total 8 Hour Intersection Volume: 10,359

Comment: 


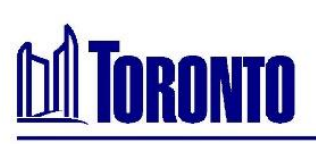

\section{City of Toronto - Traffic Safety Unit}

Turning Movement Count Summary Report

BEECROFT RD AT ELMHURST AVE (PX 1783)

Survey Date:

2013-May-02

(Thursday)

Survey Type: Routine Hours

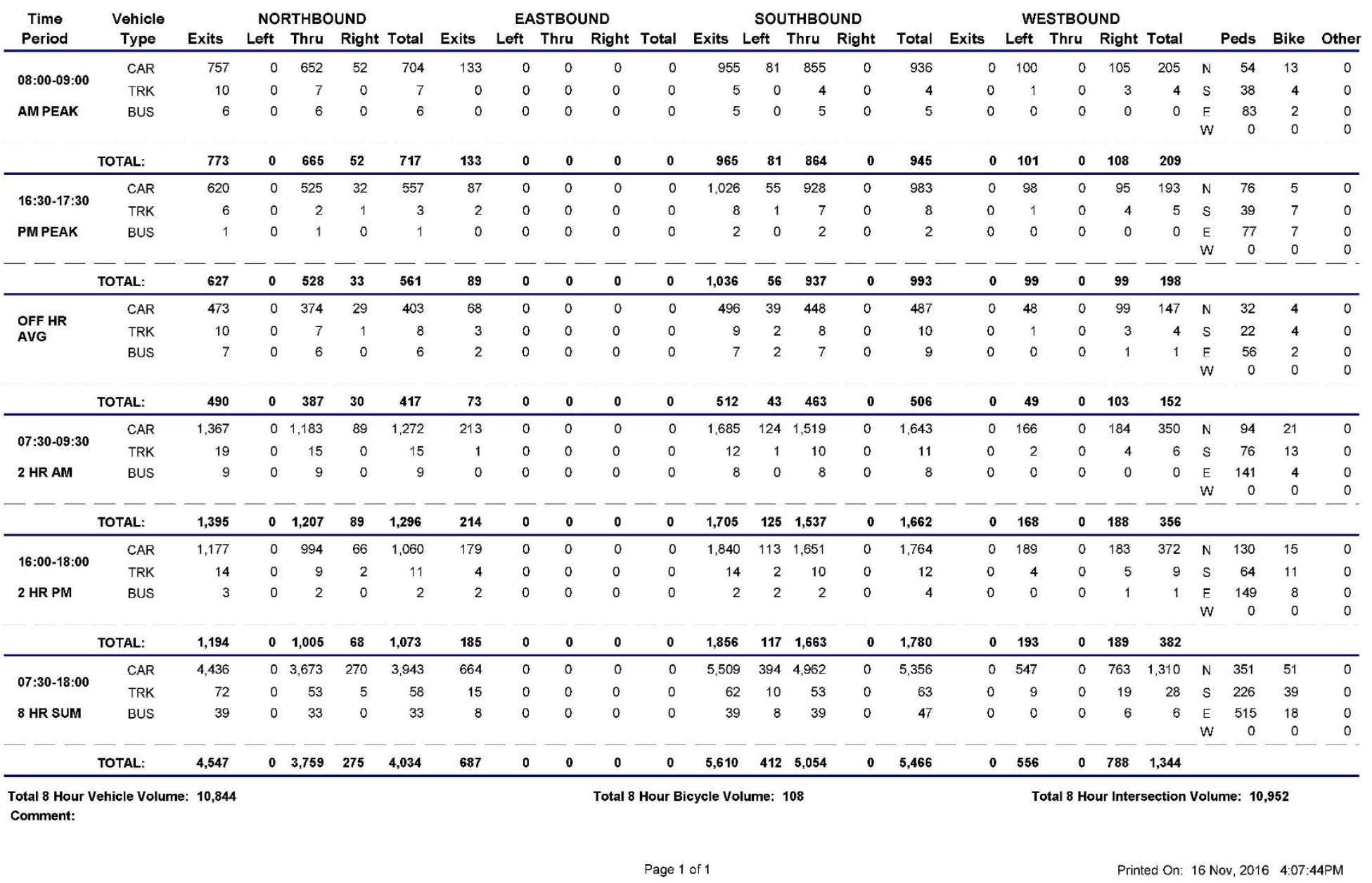


Turning Movement Count Summary Report

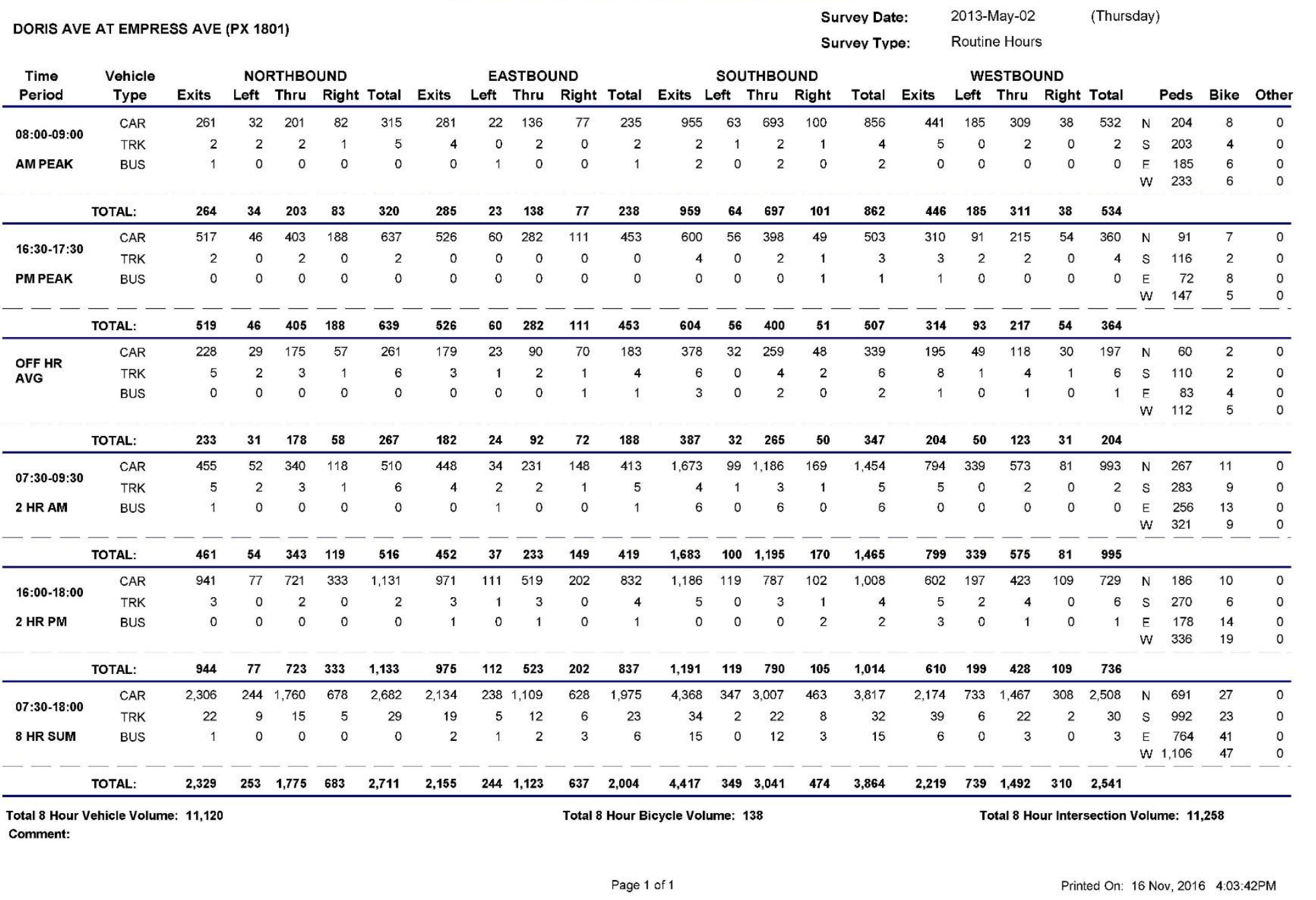


Turning Movement Count Summary Report

CHURCH AVE AT DORIS AVE (PX 1977)

(Wednesday)

\begin{tabular}{|c|c|c|c|c|c|c|c|c|c|c|c|c|c|c|c|c|c|c|c|c|c|c|c|c|c|}
\hline \multirow{2}{*}{$\begin{array}{l}\text { Time } \\
\text { Period }\end{array}$} & \multirow{2}{*}{$\begin{array}{c}\text { Vehicle } \\
\text { Type }\end{array}$} & \multirow[b]{2}{*}{ Exits } & \multicolumn{3}{|c|}{ NORTHBOUND } & \multirow[b]{2}{*}{ Total } & \multicolumn{5}{|c|}{ EASTBOUND } & \multicolumn{5}{|c|}{ SOUTHBOUND } & \multicolumn{5}{|c|}{ WESTBOUND } & \multirow{2}{*}{\multicolumn{2}{|c|}{ Peds }} & \multirow[b]{2}{*}{ Bike } & \multirow[b]{2}{*}{ Other } \\
\hline & & & Left & Thru & Right & & Exits & Left & Thru & Right & Total & Exits & Left & Thru & Right & Total & Exits & Left & Thru & Right & Total & & & & \\
\hline \multirow{2}{*}{ 08:00-09:00 } & CAR & 340 & 22 & 208 & 59 & 289 & 255 & 75 & 145 & 51 & 271 & 661 & 51 & 510 & 149 & 710 & 340 & 100 & 169 & 57 & 326 & $\mathrm{~N}$ & 131 & 0 & 0 \\
\hline & TRK & 3 & 0 & 1 & 0 & 1 & 1 & 1 & 0 & 0 & 1 & 2 & 1 & 2 & 2 & 5 & 4 & 0 & 2 & 1 & 3 & $s$ & 229 & 2 & 0 \\
\hline \multirow[t]{2}{*}{ AM PEAK } & BUS & 1 & 0 & 0 & 0 & 0 & 0 & 0 & 0 & 0 & 0 & 3 & 0 & 3 & 1 & 4 & 1 & 0 & 0 & 1 & 1 & E & 120 & 0 & 0 \\
\hline & TOTAL: & 344 & 22 & 209 & 59 & 290 & 256 & 76 & 145 & 51 & 272 & 666 & 52 & 515 & 152 & 719 & 345 & 100 & 171 & 59 & 330 & & & & \\
\hline \multirow{2}{*}{ 17:00-18:00 } & CAR & 692 & 56 & 462 & 75 & 593 & 342 & 125 & 176 & 50 & 351 & 528 & 91 & 391 & 115 & 597 & 332 & 87 & 161 & 105 & 353 & $\mathrm{~N}$ & 173 & 2 & 0 \\
\hline & TRK & 2 & 1 & 2 & 1 & 4 & 2 & 0 & 1 & 0 & 1 & 2 & 0 & 1 & 0 & 1 & 2 & 1 & 1 & 0 & 2 & $s$ & 110 & 2 & 0 \\
\hline \multirow[t]{2}{*}{ PM PEAK } & BUS & 0 & 0 & 0 & 0 & 0 & 0 & 0 & 0 & 0 & 0 & 0 & 0 & 0 & 0 & 0 & 0 & 0 & 0 & 0 & 0 & E & 128 & 0 & 0 \\
\hline & TOTAL: & 694 & 57 & 464 & 76 & 597 & 344 & 125 & 177 & 50 & 352 & 530 & 91 & 392 & 115 & 598 & 334 & 88 & 162 & 105 & 355 & & & & \\
\hline \multirow{4}{*}{$\begin{array}{l}\text { OFF HR } \\
\text { AVG }\end{array}$} & CAR & 308 & 29 & 220 & 25 & 274 & 131 & 49 & 68 & 39 & 156 & 320 & 38 & 259 & 74 & 371 & 189 & 22 & 86 & 39 & 147 & $\mathrm{~N}$ & 83 & 2 & 0 \\
\hline & TRK & 4 & 1 & 2 & 0 & 3 & 2 & 2 & 1 & 1 & 4 & 4 & 1 & 3 & 3 & 7 & 6 & 0 & 2 & 0 & 2 & $s$ & 51 & 1 & 0 \\
\hline & BUS & 0 & 0 & 0 & 0 & 0 & 0 & 0 & 0 & 0 & 0 & 0 & 0 & 0 & 0 & 0 & 0 & 0 & 0 & 0 & 0 & E & 54 & 1 & 0 \\
\hline & TOTAL: & 312 & 30 & 222 & 25 & 277 & 133 & 51 & 69 & 40 & 160 & 324 & 39 & 262 & 77 & 378 & 195 & 22 & 88 & 39 & 149 & & & & \\
\hline \multirow{2}{*}{$07: 30-09: 30$} & CAR & 616 & 38 & 387 & 86 & 511 & 405 & 127 & 218 & 110 & 455 & 1,270 & $0 \quad 101$ & 992 & 267 & 1,360 & 601 & 168 & 296 & 102 & 566 & $\mathrm{~N}$ & 204 & 2 & 0 \\
\hline & TRK & 3 & 0 & 1 & 1 & 2 & 3 & 1 & 1 & 1 & 3 & 4 & 1 & 3 & 4 & 8 & 9 & 0 & 5 & 1 & 6 & $s$ & 284 & 2 & 0 \\
\hline \multirow[t]{3}{*}{2 HR AM } & BUS & 2 & 1 & 1 & 0 & 2 & 2 & 0 & 2 & 0 & 2 & 4 & 0 & 4 & 1 & 5 & 2 & 0 & 0 & 1 & 1 & E & 177 & 1 & 0 \\
\hline & & & & - & & - & - & 工 & & 工 & & & & & & 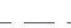 & & & & & $\cdots$ & $w$ & 208 & 2 & 0 \\
\hline & TOTAL: & 621 & 39 & 389 & 87 & 515 & 410 & 128 & 221 & 111 & 460 & 1,278 & 102 & 999 & 272 & 1,373 & 612 & 168 & 301 & 104 & 573 & & & & \\
\hline \multirow{2}{*}{ 16:00-18:00 } & CAR & 1,315 & 106 & 887 & 128 & 1,121 & 599 & 249 & 315 & 100 & 664 & 930 & 156 & 694 & 213 & 1,063 & 624 & 136 & 305 & 179 & 620 & $\mathrm{~N}$ & 335 & 5 & 0 \\
\hline & TRK & 4 & 1 & 4 & 1 & 6 & 3 & 0 & 2 & 2 & 4 & 6 & 0 & 3 & 2 & 5 & 5 & 1 & 2 & 0 & 3 & $s$ & 201 & 3 & 0 \\
\hline \multirow[t]{2}{*}{2 HR PM } & BUS & 0 & 0 & 0 & 0 & 0 & 1 & 0 & 0 & 0 & 0 & 2 & 1 & 1 & 0 & 2 & 0 & 1 & 0 & 0 & 1 & E & 242 & 0 & 0 \\
\hline & TOTAL: & 1,319 & 107 & 891 & 129 & 1,127 & 603 & 249 & 317 & 102 & 668 & 938 & 157 & $698 \mathrm{Z} \quad \mathrm{C}$ & 215 & 1,070 & 629 & 138 & 307 & 179 & 624 & & & & \\
\hline \multirow{2}{*}{ 07:30-18:00 } & CAR & 3,159 & 261 & 2,152 & 314 & 2,727 & 1,526 & 571 & 805 & 367 & 1,743 & 3,479 & 407 & $7 \quad 2,722$ & 775 & 3,904 & 1,980 & 390 & 944 & 436 & 1,770 & $\mathrm{~N}$ & 869 & 13 & 0 \\
\hline & TRK & 23 & 3 & 12 & 3 & 18 & 13 & 9 & 7 & 6 & 22 & 26 & 3 & 18 & 16 & 37 & 32 & 2 & 13 & 2 & 17 & $s$ & 688 & 10 & 0 \\
\hline \multirow[t]{2}{*}{8 HR SUM } & BUS & 2 & 1 & 1 & 0 & 2 & 3 & 0 & 2 & 0 & 2 & 7 & 1 & 6 & 1 & 8 & 2 & 1 & 0 & 1 & 2 & E & 635 & 3 & 0 \\
\hline & TOTAL: & 3,184 & 265 & 2,165 & 317 & 2,747 & 1,542 & 580 & 814 & 373 & 1,767 & 3,512 & 411 & 12,746 & 792 & 3,949 & 2,014 & 393 & 957 & 439 & 1,789 & & & & \\
\hline
\end{tabular}

Total 8 Hour Vehicle Volume: 10,252

Total 8 Hour Bicycle Volume: 30

Total 8 Hour Intersection Volume: $\mathbf{1 0 , 2 8 2}$

Comment:

Page 1 of 1

Printed On: 16 Nov, 2016 3:59:59PM 
Turning Movement Count Summary Report

BYNG AVE AT DORIS AVE (PX 2192)

\begin{tabular}{|c|c|c|c|c|c|c|c|c|c|c|c|c|c|c|c|c|c|c|c|c|c|c|c|c|c|}
\hline \multirow{2}{*}{$\begin{array}{l}\text { Time } \\
\text { Period }\end{array}$} & \multirow{2}{*}{$\begin{array}{c}\text { Vehicle } \\
\text { Type }\end{array}$} & \multirow[b]{2}{*}{ Exits } & \multicolumn{3}{|c|}{ NORTHBOUND } & \multirow[b]{2}{*}{ Total } & \multicolumn{5}{|c|}{ EASTBOUND } & \multicolumn{5}{|c|}{ SOUTHBOUND } & \multicolumn{5}{|c|}{ WESTBOUND } & \multirow{2}{*}{\multicolumn{2}{|c|}{ Peds }} & \multirow[b]{2}{*}{ Bike } & \multirow[b]{2}{*}{ Other } \\
\hline & & & Left & Thru & Right & & Exits & Left & Thru & Right & Total & Exits & Left & Thru & Right & Total & Exits & Left & Thru & Right 7 & Total & & & & \\
\hline \multirow{2}{*}{ 08:00-09:00 } & CAR & 435 & 32 & 403 & 37 & 472 & 86 & 5 & 11 & 8 & 24 & 733 & 38 & 658 & 10 & 706 & 68 & 67 & 26 & 27 & 120 & $\mathrm{~N}$ & 87 & 0 & 0 \\
\hline & TRK & 1 & 0 & 1 & 0 & 1 & 0 & 0 & 0 & 0 & 0 & 3 & 0 & 3 & 0 & 3 & 1 & 0 & 1 & 0 & 1 & $s$ & 75 & 2 & 0 \\
\hline \multirow[t]{2}{*}{ AM PEAK } & BUS & 4 & 1 & 3 & 0 & 4 & 1 & 1 & 0 & 0 & 1 & 2 & 1 & 1 & 0 & 2 & 1 & 1 & 0 & 0 & 1 & $\begin{array}{l}E \\
W\end{array}$ & $\begin{array}{l}82 \\
70\end{array}$ & $\begin{array}{l}0 \\
0\end{array}$ & $\begin{array}{l}0 \\
0\end{array}$ \\
\hline & TOTAL: & 440 & 33 & 407 & 37 & 477 & 87 & 6 & 11 & 8 & 25 & 738 & 39 & 662 & 10 & 711 & 70 & 68 & 27 & 27 & 122 & & & & \\
\hline \multirow{2}{*}{ 17:00-18:00 } & CAR & 544 & 23 & 501 & 25 & 549 & 68 & 19 & 11 & 21 & 51 & 562 & 32 & 519 & 10 & 561 & 40 & 22 & 7 & 24 & 53 & $\mathrm{~N}$ & 64 & 1 & 0 \\
\hline & TRK & 0 & 0 & 0 & 0 & 0 & 0 & 0 & 0 & 0 & 0 & 2 & 0 & 2 & 0 & 2 & 0 & 0 & 0 & 0 & 0 & $s$ & 61 & 2 & 0 \\
\hline \multirow[t]{3}{*}{ PM PEAK } & BUS & 0 & 0 & 0 & 0 & 0 & 0 & 0 & 0 & 0 & 0 & 1 & 0 & 1 & 0 & 1 & 0 & 0 & 0 & 0 & 0 & E & 56 & 0 & 0 \\
\hline & - & - & - & - & $\ldots$ & - & - & 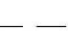 & $\ldots$ & - & 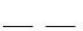 & 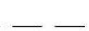 & - - & - & - & - & - & 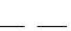 & & 工 & $\ldots$ & $w$ & 104 & 0 & 0. \\
\hline & TOTAL: & 544 & 23 & 501 & 25 & 549 & 68 & 19 & 11 & 21 & 51 & 565 & 32 & 522 & 10 & 564 & 40 & 22 & 7 & 24 & 53 & & & & \\
\hline \multirow{4}{*}{$\begin{array}{l}\text { OFF HR } \\
\text { AVG }\end{array}$} & CAR & 254 & 26 & 237 & 10 & 273 & 26 & 6 & 6 & 14 & 26 & 301 & 10 & 276 & 12 & 298 & 46 & 11 & 8 & 11 & 30 & $\mathrm{~N}$ & 35 & 2 & 0 \\
\hline & TRK & 5 & 0 & 3 & 0 & 3 & 0 & 1 & 0 & 1 & 2 & 5 & 0 & 4 & 1 & 5 & 1 & 0 & 0 & 1 & 1 & $s$ & 37 & 2 & 0 \\
\hline & BUS & 1 & 0 & 0 & 0 & 0 & 0 & 1 & 0 & 0 & 1 & 1 & 0 & 1 & 0 & 1 & 0 & 0 & 0 & 0 & 0 & E & 30 & 0 & 0 \\
\hline & TOTAL: & 260 & 26 & 240 & 10 & 276 & 26 & 8 & 6 & 15 & 29 & 307 & 10 & 281 & 13 & 304 & 47 & 11 & 8 & 12 & 31 & & & & \\
\hline \multirow{2}{*}{$07: 30-09: 30$} & CAR & 716 & 51 & 664 & 49 & 764 & 123 & 9 & 14 & 15 & 38 & 1,266 & 60 & 1,157 & 15 & 1,232 & 105 & 94 & 39 & 43 & 176 & $\mathrm{~N}$ & 150 & 5 & 0 \\
\hline & TRK & 2 & 1 & 2 & 0 & 3 & 0 & 0 & 0 & 0 & 0 & 6 & 0 & 6 & 0 & 6 & 2 & 0 & 1 & 0 & 1 & $s$ & 118 & 4 & 0 \\
\hline \multirow[t]{3}{*}{2 HR AM } & BUS & 5 & 2 & 4 & 0 & 6 & 1 & 1 & 0 & 0 & 1 & 8 & 1 & 6 & 0 & 7 & 2 & 2 & 0 & 0 & 2 & E & 143 & 3 & 0 \\
\hline & --- & & & - & -- & - & - - & - & - - & - & 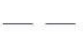 & - & - - & - & - & - & - - & - & - & - & - & w & 120 & 0 & 0 \\
\hline & TOTAL: & 723 & 54 & 670 & 49 & 773 & 124 & 10 & 14 & 15 & 39 & 1,280 & 61 & 1,169 & 15 & 1,245 & 109 & 96 & 40 & 43 & 179 & & & & \\
\hline \multirow{2}{*}{$16: 00-18: 00$} & CAR & 1,044 & 43 & 950 & 45 & 1,038 & 115 & 44 & 23 & 39 & 106 & 966 & 47 & 894 & 19 & 960 & 78 & 33 & 16 & 50 & 99 & $\mathrm{~N}$ & 117 & 5 & 0 \\
\hline & TRK & 4 & 0 & 4 & 0 & 4 & 1 & 0 & 1 & 1 & 2 & 4 & 0 & 3 & 0 & 3 & 1 & 0 & 1 & 0 & 1 & $s$ & 118 & 2 & 0 \\
\hline \multirow[t]{3}{*}{2 HR PM } & BUS & 2 & 0 & 1 & 0 & 1 & 0 & 1 & 0 & 0 & 1 & 4 & 0 & 4 & 0 & 4 & 0 & 0 & 0 & 0 & 0 & E & 109 & 2 & 0 \\
\hline & & & & & & & & & & & & & & & & & & & & & & & & & \\
\hline & TOTAL: & 1,050 & 43 & 955 & 45 & 1,043 & 116 & 45 & 24 & 40 & 109 & 974 & 47 & 901 & 19 & 967 & 79 & 33 & 17 & 50 & 100 & & & & \\
\hline \multirow{2}{*}{ 07:30-18:00 } & CAR & 2,779 & 198 & 2,563 & 135 & 2,896 & 341 & 78 & 60 & 110 & 248 & 3,438 & 146 & 3,156 & 82 & 3,384 & 365 & 172 & 85 & 138 & 395 & $\mathrm{~N}$ & 408 & 17 & 0 \\
\hline & TRK & 22 & 1 & 18 & 1 & 20 & 4 & 2 & 2 & 5 & 9 & 28 & 1 & 23 & 2 & 26 & 6 & 0 & 3 & 2 & 5 & s & 382 & 14 & 0 \\
\hline \multirow[t]{2}{*}{8 HR SUM } & BUS & 9 & 3 & 5 & 0 & 8 & 2 & 4 & 0 & 0 & 4 & 17 & 2 & 14 & 0 & 16 & 3 & 3 & 0 & 0 & 3 & $E$ & $\begin{array}{l}371 \\
557\end{array}$ & $\begin{array}{l}5 \\
1\end{array}$ & $\begin{array}{l}0 \\
0\end{array}$ \\
\hline & TOTAL: & 2,810 & 202 & 2,586 & 136 & 2,924 & 347 & 84 & 62 & 115 & 261 & 3,483 & 149 & 3,193 & 84 & 3,426 & 374 & 175 & 88 & 140 & 403 & & & & \\
\hline
\end{tabular}




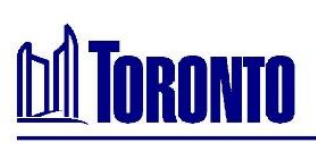

\section{City of Toronto - Traffic Safety Unit}

Turning Movement Count Summary Report

BEECROFT ROAD AT CHURCHILL AVE (PX 2299)

\begin{tabular}{|c|c|c|c|c|c|c|c|c|c|c|c|c|c|c|c|c|c|c|c|c|c|c|c|c|c|}
\hline \multirow{3}{*}{$\begin{array}{c}\text { Time } \\
\text { Period } \\
\end{array}$} & \multirow{3}{*}{$\begin{array}{c}\text { Vehicle } \\
\text { Type }\end{array}$} & \multirow{2}{*}{\multicolumn{5}{|c|}{ NORTHBOUND }} & \\
\hline & & & & & & & & & STBOL & UND & & & sou & THBOL & UND & & & & STBOU & UND & & & & & \\
\hline & & Exits & Left & Thru & Right & Total & Exits & Left & Thru & Right & Total & Exits & Left & Thru & Right & Total & Exits & Left & Thru & Right & Total & & Peds & Bike & Other \\
\hline \multirow{2}{*}{$08: 15-09: 15$} & CAR & 303 & 24 & 230 & 34 & 288 & 175 & 46 & 99 & 45 & 190 & 625 & 42 & 536 & 46 & 624 & 195 & 44 & 125 & 27 & 196 & $\mathrm{~N}$ & 21 & 9 & 0 \\
\hline & TRK & 1 & 1 & 1 & 0 & 2 & 2 & 0 & 1 & 0 & 1 & 3 & 1 & 3 & 1 & 5 & 5 & 0 & 3 & 0 & 3 & $s$ & 19 & 4 & 0 \\
\hline \multirow[t]{2}{*}{ AM PEAK } & BUS & 2 & 2 & 2 & 1 & 5 & 5 & 0 & 2 & 0 & 2 & 2 & 2 & 2 & 1 & 5 & 5 & 0 & 2 & 0 & 2 & E & 18 & 0 & 0 \\
\hline & TOTAL: & 306 & 27 & 233 & 35 & 295 & 182 & 46 & 102 & 45 & 193 & 630 & 45 & 541 & 48 & 634 & 205 & 44 & 130 & 27 & 201 & & & & \\
\hline \multirow{2}{*}{$16: 30-17: 30$} & CAR & 531 & 33 & 458 & 59 & 550 & 215 & 23 & 114 & 30 & 167 & 324 & 42 & 267 & 37 & 346 & 206 & 27 & 136 & 50 & 213 & $\mathrm{~N}$ & 26 & 13 & 0 \\
\hline & TRK & 1 & 0 & 1 & 0 & 1 & 3 & 0 & 1 & 0 & 1 & 4 & 2 & 4 & 0 & 6 & 2 & 0 & 2 & 0 & 2 & $s$ & 19 & 9 & 0 \\
\hline \multirow{3}{*}{$\begin{array}{l}\text { PM PEAK } \\
--\ldots\end{array}$} & BUS & 0 & 0 & 0 & 0 & 0 & 0 & 0 & 0 & 0 & 0 & 1 & 0 & 1 & 0 & 1 & 0 & 0 & 0 & 0 & 0 & E & 16 & 7 & 0 \\
\hline & --- & - & -- & - & -- & -- & -1 & - & -- & - & - & -- & -1 & -- & -7 & -- & -- & - & -- & - & -- & $-\frac{w}{2}$ & 36 & -6 & \\
\hline & TOTAL: & 532 & 33 & 459 & 59 & 551 & 218 & 23 & 115 & 30 & 168 & 329 & 44 & 272 & 37 & 353 & 208 & 27 & 138 & 50 & 215 & & & & \\
\hline \multirow{5}{*}{$\begin{array}{l}\text { OFF HR } \\
\text { AVG }\end{array}$} & CAR & 244 & 13 & 200 & 23 & 236 & 102 & 19 & 60 & 18 & 97 & 215 & 19 & 181 & 21 & 221 & 90 & 16 & 56 & 25 & 97 & $\mathrm{~N}$ & 10 & 3 & 0 \\
\hline & TRK & 5 & 1 & 2 & 1 & 4 & 4 & 1 & 3 & 0 & 4 & 2 & 0 & 2 & 0 & 2 & 4 & 0 & 3 & 2 & 5 & s & 13 & 4 & 0 \\
\hline & BUS & 2 & 0 & 2 & 1 & 3 & 2 & 0 & 1 & 1 & 2 & 3 & 0 & 2 & 0 & 2 & 0 & 0 & 0 & 0 & 0 & $E$ & $\begin{array}{r}9 \\
27\end{array}$ & 1 & $\begin{array}{l}0 \\
0\end{array}$ \\
\hline & TOTAL: & 251 & 14 & 204 & 25 & 243 & 108 & 20 & 64 & 19 & 103 & 220 & 19 & 185 & 21 & 225 & 94 & 16 & 59 & 27 & 102 & & & & \\
\hline & CAR & 536 & 48 & 413 & 54 & 515 & 306 & 68 & 177 & 82 & 327 & 1,162 & 75 & 990 & 65 & 1,130 & 318 & 90 & 205 & 55 & 350 & $\mathrm{~N}$ & 25 & 14 & 0 \\
\hline $07: 30-09: 30$ & TRK & 2 & 4 & 2 & 0 & 6 & 4 & 0 & 2 & 0 & 2 & 4 & 2 & 4 & 1 & 7 & 10 & 0 & 5 & 0 & 5 & $s$ & 25 & 9 & 0 \\
\hline \multirow[t]{3}{*}{2 HR AM } & BUS & 2 & 2 & 2 & 3 & 7 & 10 & 0 & 5 & 0 & 5 & 3 & 2 & 3 & 2 & 7 & 8 & 0 & 4 & 0 & 4 & E & 20 & 2 & 0 \\
\hline & $\overline{-}-$ & & & 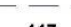 & & & -1 & & & & & & & & & - & & & & & & & & & \\
\hline & TOIAL: & 040 & 34 & 411 & $5 r$ & 528 & 320 & 68 & 784 & 82 & 334 & 1,169 & 19 & 991 & 68 & 1,144 & 336 & 90 & 274 & 0 & 000 & & & & \\
\hline \multirow{2}{*}{$16: 00-18: 00$} & CAR & 980 & 60 & 834 & 106 & 1,000 & 385 & 45 & 204 & 52 & 301 & 638 & 75 & 538 & 71 & 684 & 371 & 48 & 240 & 101 & 389 & $\mathrm{~N}$ & 52 & 19 & 0 \\
\hline & TRK & 4 & 0 & 3 & 2 & 5 & 7 & 0 & 3 & 0 & 3 & 7 & 2 & 7 & 1 & 10 & 5 & 0 & 4 & 1 & 5 & s & 39 & 14 & 0 \\
\hline \multirow[t]{2}{*}{2 HR PM } & BUS & 2 & 1 & 1 & 0 & 2 & 0 & 1 & 0 & 0 & 1 & 2 & 0 & 1 & 0 & 1 & 1 & 1 & 0 & 0 & 1 & E & 35 & 12 & $\begin{array}{l}0 \\
0\end{array}$ \\
\hline & TOTAL: & 986 & 61 & 838 & 108 & 1,007 & 392 & 46 & 207 & 52 & 305 & 647 & 77 & 546 & 72 & 695 & 377 & 49 & 244 & 102 & 395 & & & & \\
\hline \multirow{2}{*}{ 07:30-18:00 } & CAR & 2,490 & 159 & 2,047 & 252 & 2,458 & 1,099 & 189 & 620 & 207 & 1,016 & 2,659 & 227 & 2,251 & 221 & 2,699 & 1,048 & 201 & 668 & 254 & 1,123 & $\mathrm{~N}$ & 115 & 44 & 0 \\
\hline & TRK & 20 & 6 & 11 & 6 & 23 & 28 & 2 & 18 & 1 & 21 & 21 & 4 & 20 & 3 & 27 & 29 & 0 & 20 & 7 & 27 & $s$ & 115 & 39 & 0 \\
\hline \multirow[t]{3}{*}{8 HR SUM } & BUS & 14 & 4 & 12 & 6 & 22 & 15 & 2 & 7 & 2 & 11 & 14 & 2 & 10 & 3 & 15 & 12 & 2 & 5 & 0 & 7 & E & 89 & 10 & 0 \\
\hline & & & & & & & & & & & & & & & & & & & & & & & & & \\
\hline & TOTAL: & 2,524 & 169 & 2,070 & 264 & 2,503 & 1,142 & 193 & 645 & 210 & 1,048 & 2,694 & 233 & 2,281 & 227 & 2,741 & 1,089 & 203 & 693 & 261 & 1,157 & & & & \\
\hline
\end{tabular}

Total 8 Hour Vehicle Volume: 7,449

Total 8 Hour Bicycle Volume: 121

Total 8 Hour Intersection Volume: 7,570

Comment: 


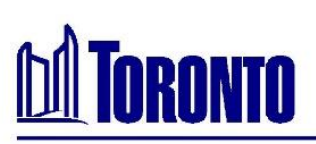

\section{City of Toronto - Traffic Safety Unit}

Turning Movement Count Summary Report

BEECROFT ROAD AT ELLERSLIE AVE (PX 2300)

Survey Date:

2013-May-02

(Thursday)

Survey Type: Routine Hours

\begin{tabular}{|c|c|c|c|c|c|c|c|c|c|c|c|c|c|c|c|c|c|c|c|c|c|c|c|c|c|}
\hline \multirow{2}{*}{$\begin{array}{c}\text { Time } \\
\text { Period }\end{array}$} & \multirow{2}{*}{$\begin{array}{c}\text { Vehicle } \\
\text { Type } \\
\end{array}$} & \multirow[b]{2}{*}{ Exits } & \multicolumn{3}{|c|}{ NORTHBOUND } & \multirow[b]{2}{*}{ Total } & \multirow[b]{2}{*}{ Exits } & \multicolumn{4}{|c|}{ EASTBOUND } & \multicolumn{5}{|c|}{ SOUTHBOUND } & \multicolumn{5}{|c|}{ WESTBOUND } & \multirow{2}{*}{\multicolumn{2}{|c|}{ Peds }} & \multirow[b]{2}{*}{ Bike } & \multirow[b]{2}{*}{ Othe } \\
\hline & & & Left & Thru & Right & & & Left & Thru & Right & Total & Exits & Left & Thru & Right & Total & Exits & Left & Thru & Right & Total & & & & \\
\hline \multirow{2}{*}{ 08:15-09:15 } & CAR & 276 & 0 & 254 & 32 & 286 & 44 & 0 & 0 & 0 & 0 & 714 & 12 & 607 & 0 & 619 & 0 & 107 & 0 & 22 & 129 & $\mathrm{~N}$ & 3 & 10 & 0 \\
\hline & TRK & 11 & 0 & 11 & 5 & 16 & 5 & 0 & 0 & 0 & 0 & 12 & 0 & 11 & 0 & 11 & 0 & 1 & 0 & 0 & 1 & $s$ & 35 & 4 & 0 \\
\hline \multirow[t]{2}{*}{ AM PEAK } & BUS & 4 & 0 & 4 & 0 & 4 & 0 & 0 & 0 & 0 & 0 & 2 & 0 & 2 & 0 & 2 & 0 & 0 & 0 & 0 & 0 & E & 9 & 0 & 0 \\
\hline & TOTAL: & 291 & 0 & 269 & 37 & 306 & 49 & 0 & 0 & 0 & 0 & 728 & 12 & 620 & 0 & 632 & 0 & 108 & 0 & 22 & 130 & & & & \\
\hline \multirow{2}{*}{ 16:15-17:15 } & CAR & 541 & 0 & 518 & 53 & 571 & 63 & 0 & 0 & 0 & 0 & 348 & 10 & 308 & 0 & 318 & 0 & 40 & 0 & 23 & 63 & $\mathrm{~N}$ & 3 & 10 & 0 \\
\hline & TRK & 10 & 0 & 9 & 1 & 10 & 1 & 0 & 0 & 0 & 0 & 8 & 0 & 7 & 0 & 7 & 0 & 1 & 0 & 1 & 2 & $s$ & 19 & 19 & 0 \\
\hline \multirow[t]{3}{*}{ PM PEAK } & BUS & 1 & 0 & 1 & 0 & 1 & 0 & 0 & 0 & 0 & 0 & 0 & 0 & 0 & 0 & 0 & 0 & 0 & 0 & 0 & 0 & E & 23 & 1 & 0 \\
\hline & - & 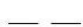 & -1 & - & $-\ldots$ & - & - & 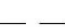 & - & - & 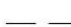 & - & - . & $\ldots$ & - & - & -- & 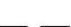 & 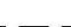 & 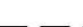 & 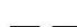 & w & 0 & 0 & 0 \\
\hline & TOTAL: & 552 & 0 & 528 & 54 & 582 & 64 & 0 & 0 & 0 & 0 & 356 & 10 & 315 & 0 & 325 & 0 & 41 & 0 & 24 & 65 & & & & \\
\hline \multirow{3}{*}{$\begin{array}{l}\text { OFF HR } \\
\text { AVG }\end{array}$} & CAR & 226 & 0 & 215 & 27 & 242 & 37 & 0 & 0 & 0 & 0 & 229 & 10 & 198 & 0 & 208 & 0 & 31 & 0 & 11 & 42 & $\mathrm{~N}$ & 2 & 4 & 0 \\
\hline & TRK & 12 & 0 & 11 & 4 & 15 & 4 & 0 & 0 & 0 & 0 & 11 & 0 & 7 & 0 & 7 & 0 & 4 & 0 & 1 & 5 & s & 9 & 4 & 0 \\
\hline & BUS & 3 & 0 & 3 & 0 & 3 & 0 & 0 & 0 & 0 & 0 & 2 & 0 & 2 & 0 & 2 & 0 & 0 & 0 & 0 & 0 & E & 14 & 1 & 0 \\
\hline \multicolumn{2}{|r|}{ TOTAL: } & 241 & 0 & 229 & 31 & 260 & 41 & 0 & 0 & 0 & 0 & 242 & 10 & 207 & 0 & 217 & 0 & 35 & 0 & 12 & 47 & & & & \\
\hline \multirow{2}{*}{$07: 30-09: 30$} & CAR & 473 & 0 & 436 & 53 & 489 & 75 & 0 & 0 & 0 & 0 & 1,290 & 22 & 1,076 & 0 & 1,098 & 0 & 214 & 0 & 37 & 251 & $\mathrm{~N}$ & 3 & 20 & 0 \\
\hline & TRK & 25 & 0 & 24 & 6 & 30 & 6 & 0 & 0 & 0 & 0 & 22 & 0 & 18 & 0 & 18 & 0 & 4 & 0 & 1 & 5 & $s$ & 58 & 9 & 0 \\
\hline \multirow{3}{*}{$\begin{array}{l}2 \text { HR AM } \\
-\end{array}$} & BUS & 6 & 0 & 6 & 1 & 7 & 1 & 0 & 0 & 0 & 0 & 3 & 0 & 3 & 0 & 3 & 0 & 0 & 0 & 0 & 0 & E & 24 & 0 & 0 \\
\hline & - & 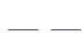 & $\cdots$ & $\ldots$ & - & - & - & 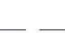 & -8 & 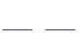 & $\ldots$ & $-\ldots$ & - & - & - & - & $-\ldots$ & - & -1 & $\ldots$ & 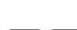 & w & 0 & 0 & 0 \\
\hline & TOTAL: & 504 & 0 & 466 & 60 & 526 & 82 & 0 & 0 & 0 & 0 & 1,315 & 22 & 1,097 & 0 & 1,119 & 0 & 218 & 0 & 38 & 256 & & & & \\
\hline $10 \cdot 0-18 \cdot 0$ & CAR & 977 & 0 & 945 & 102 & 1,047 & 126 & 0 & 0 & 0 & 0 & 703 & 24 & 615 & 0 & 639 & 0 & 88 & 0 & 32 & 120 & $\mathrm{~N}$ & 11 & 24 & 0 \\
\hline $16: 00-18: 00$ & TRK & 18 & 0 & 15 & 3 & 18 & 5 & 0 & 0 & 0 & 0 & 10 & 2 & 9 & 0 & 11 & 0 & 1 & 0 & 3 & 4 & $s$ & 42 & 22 & 0 \\
\hline 2 HR PM & BUS & 1 & 0 & 1 & 0 & 1 & 0 & 0 & 0 & 0 & 0 & 1 & 0 & 1 & 0 & 1 & 0 & 0 & 0 & 0 & 0 & E & 43 & 3 & 0 \\
\hline & TOTAL: & 996 & 0 & 961 & 105 & 1,066 & 131 & 0 & 0 & 0 & 0 & 714 & 26 & 625 & 0 & 651 & 0 & 89 & 0 & 35 & 124 & & & & \\
\hline & CAR & 2,355 & 0 & 2,241 & 262 & 2,503 & 348 & 0 & 0 & 0 & 0 & 2,908 & 86 & 2,481 & 0 & 2,567 & 0 & 427 & 0 & 114 & 541 & $\mathrm{~N}$ & 23 & 61 & 0 \\
\hline $07: 30-18: 00$ & TRK & 89 & 0 & 81 & 24 & 105 & 26 & 0 & 0 & 0 & 0 & 77 & 2 & 56 & 0 & 58 & 0 & 21 & 0 & 8 & 29 & $\mathrm{~s}$ & 136 & 46 & 0 \\
\hline 8 HR SUM & BUS & 19 & 0 & 19 & 1 & 20 & 1 & 0 & 0 & 0 & 0 & 10 & 0 & 10 & 0 & 10 & 0 & 0 & 0 & 0 & 0 & E & 123 & 5 & 0 \\
\hline & & & & & & & - & & & & & & & & & & & & & & & W & & & 0 \\
\hline & TOTAL: & 2,463 & 0 & 2,341 & 287 & 2,628 & 375 & 0 & 0 & 0 & 0 & 2,995 & 88 & 2,547 & 0 & 2,635 & 0 & 448 & 0 & 122 & 570 & & & & \\
\hline $\begin{array}{l}\text { Total } 8 \text { Hour } \\
\text { Comment: }\end{array}$ & Vehicle Volun & e: $\mathbf{5 , 8 3 3}$ & & & & & & & & Total \& & 8 Hour B & icycle Volu & lume: 1 & & & & & & otal $8 \mathrm{Ho}$ & our Inters & rsection & Vols & me: 5,9 & & \\
\hline
\end{tabular}




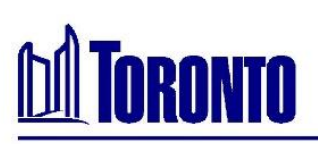

\section{City of Toronto - Traffic Safety Unit}

Turning Movement Count Summary Report

BEECROFT ROAD AT KEMPFORD BLVD (PX 2305)

Survey Date:

2010-May-10

(Wednesday)

\begin{tabular}{|c|c|c|c|c|c|c|c|c|c|c|c|c|c|c|c|c|c|c|c|c|c|c|c|c|c|}
\hline \multirow{3}{*}{$\begin{array}{l}\text { Time } \\
\text { Period }\end{array}$} & \multirow{3}{*}{$\begin{array}{l}\text { Vehicle } \\
\text { Type }\end{array}$} & \multirow{2}{*}{\multicolumn{5}{|c|}{ NORTHBOUND }} & \multirow{2}{*}{\multicolumn{5}{|c|}{ EASTBOUND }} & & & & & & & & & & & & & & \\
\hline & & & & & & & & & & & & & sou & JTHBOI & UND & & & & ESTBOU & UND & & & & & \\
\hline & & Exits & Left & Thru & Right & Total & Exits & Left & Thru & Right & Total & Exits $L$ & Left & Thru & Right & Total & Exits & Left & Thru & Right & Total & & Peds & Bike & Other \\
\hline \multirow{2}{*}{$08: 15-09: 15$} & CAR & 482 & 0 & 410 & 61 & 471 & 121 & 0 & 0 & 0 & 0 & 809 & 60 & 740 & 0 & 800 & 0 & 69 & 0 & 72 & 141 & $\mathrm{~N}$ & 52 & 1 & 0 \\
\hline & TRK & 4 & 0 & 3 & 0 & 3 & 0 & 0 & 0 & 0 & 0 & 8 & 0 & 8 & 0 & 8 & 0 & 0 & 0 & 1 & 1 & $s$ & 44 & 4 & 0 \\
\hline \multirow[t]{2}{*}{ AM PEAK } & BUS & 2 & 0 & 1 & 0 & 1 & 0 & 0 & 0 & 0 & 0 & 3 & 0 & 1 & 0 & 1 & 0 & 2 & 0 & 1 & 3 & E & 62 & 0 & 0 \\
\hline & TOTAL: & 488 & 0 & 414 & 61 & 475 & 121 & 0 & 0 & 0 & 0 & 820 & 60 & 749 & 0 & 809 & 0 & 71 & 0 & 74 & 145 & & & & \\
\hline \multirow{2}{*}{ 16:45-17:45 } & CAR & 820 & 0 & 780 & 48 & 828 & 88 & 0 & 0 & 0 & 0 & 508 & 40 & 476 & 0 & 516 & 0 & 32 & 0 & 40 & 72 & $\mathrm{~N}$ & 29 & 7 & 0 \\
\hline & TRK & 4 & 0 & 3 & 0 & 3 & 0 & 0 & 0 & 0 & 0 & 1 & 0 & 1 & 0 & 1 & 0 & 0 & 0 & 1 & 1 & $s$ & 17 & 4 & 0 \\
\hline \multirow[t]{2}{*}{ PM PEAK } & BUS & 0 & 0 & 0 & 0 & 0 & 0 & 0 & 0 & 0 & 0 & 0 & 0 & 0 & 0 & 0 & 0 & 0 & 0 & 0 & 0 & E & 46 & 0 & 0 \\
\hline & TOTAL: & 824 & 0 & $\overline{783}$ & 48 & $\overline{831}$ & 88 & 0 & 0 & 0 & 0 & 509 & 40 & 477 & 0 & $\overline{517}$ & 0 & 32 & 0 & 41 & 73 & & & & \\
\hline \multirow{4}{*}{$\begin{array}{l}\text { OFF HR } \\
\text { AVG }\end{array}$} & CAR & 355 & 0 & 328 & 24 & 352 & 49 & 0 & 0 & 0 & 0 & 313 & 25 & 297 & 0 & 322 & 0 & 16 & 0 & 27 & 43 & $\mathrm{~N}$ & 12 & 2 & 0 \\
\hline & TRK & 4 & 0 & 4 & 0 & 4 & 1 & 0 & 0 & 0 & 0 & 4 & 1 & 4 & 0 & 5 & 0 & 0 & 0 & 0 & 0 & $\mathrm{~s}$ & 17 & 2 & 0 \\
\hline & BUS & 1 & 0 & 1 & 0 & 1 & 0 & 0 & 0 & 0 & 0 & 0 & 0 & 0 & 0 & 0 & 0 & 0 & 0 & 0 & 0 & E & 35 & 0 & $\begin{array}{l}0 \\
0\end{array}$ \\
\hline & TOTAL: & 360 & 0 & 333 & 24 & 357 & 50 & 0 & 0 & 0 & 0 & 317 & 26 & 301 & 0 & 327 & 0 & 16 & 0 & 27 & 43 & & & & \\
\hline \multirow{2}{*}{$07: 30-09: 30$} & CAR & 839 & 0 & 732 & 93 & 825 & 181 & 0 & 0 & 0 & 0 & 1,497 & 88 & 1,383 & 0 & 1,471 & 0 & 114 & 0 & 107 & 221 & $\mathrm{~N}$ & 66 & 2 & 0 \\
\hline & TRK & 5 & 0 & 4 & 0 & 4 & 0 & 0 & 0 & 0 & 0 & 11 & 0 & 11 & 0 & 11 & 0 & 0 & 0 & 1 & 1 & $s$ & 68 & 5 & 0 \\
\hline \multirow[t]{2}{*}{2 HR AM } & BUS & 2 & 0 & 1 & 0 & 1 & 0 & 0 & 0 & 0 & 0 & 3 & 0 & 1 & 0 & 1 & 0 & 2 & 0 & 1 & 3 & E & 105 & 1 & 0 \\
\hline & TOTAL: & 846 & 0 & 737 & 93 & 830 & 181 & 0 & 0 & 0 & 0 & 1,511 & 88 & 1,395 & 0 & 1,483 & 0 & 116 & 0 & 109 & 225 & & & & \\
\hline \multirow{2}{*}{ 16:00-18:00 } & CAR & 1,579 & 0 & 1,487 & 91 & 1,578 & 164 & 0 & 0 & 0 & 0 & 961 & 73 & 899 & 0 & 972 & 0 & 62 & 0 & 92 & 154 & $\mathrm{~N}$ & 53 & 9 & 0 \\
\hline & TRK & 9 & 0 & 7 & 0 & 7 & 0 & 0 & 0 & 0 & 0 & 5 & 0 & 4 & 0 & 4 & 0 & 1 & 0 & 2 & 3 & $s$ & 56 & 5 & 0 \\
\hline \multirow[t]{2}{*}{2 HR PM } & BUS & 1 & 0 & 1 & 0 & 1 & 0 & 0 & 0 & 0 & 0 & 1 & 0 & 1 & 0 & 1 & 0 & 0 & 0 & 0 & 0 & $E$ & $\begin{array}{r}101 \\
0\end{array}$ & $\begin{array}{l}0 \\
0\end{array}$ & $\begin{array}{l}0 \\
0\end{array}$ \\
\hline & TOTAL: & 1,589 & 0 & 1,495 & 91 & 1,586 & 164 & 0 & 0 & 0 & 0 & 967 & 73 & 904 & 0 & 977 & 0 & 63 & 0 & 94 & 157 & & & & \\
\hline \multirow{2}{*}{$07: 30-18: 00$} & CAR & 3,840 & 0 & 3,532 & 278 & 3,810 & 537 & 0 & 0 & 0 & 0 & 3,710 & 259 & 3,471 & 0 & 3,730 & 0 & 239 & 0 & 308 & 547 & $\mathrm{~N}$ & 167 & 19 & 0 \\
\hline & TRK & 28 & 0 & 25 & 1 & 26 & 3 & 0 & 0 & 0 & 0 & 33 & 2 & 32 & 0 & 34 & 0 & 1 & 0 & 3 & 4 & $s$ & 190 & 18 & 0 \\
\hline \multirow[t]{2}{*}{8 HR SUM } & BUS & 6 & 0 & 5 & 0 & 5 & 1 & 0 & 0 & 0 & 0 & 6 & 1 & 3 & 0 & 4 & 0 & 3 & 0 & 1 & 4 & $\begin{array}{l}E \\
W\end{array}$ & $\begin{array}{r}345 \\
0\end{array}$ & $\begin{array}{l}2 \\
0\end{array}$ & $\begin{array}{l}0 \\
0\end{array}$ \\
\hline & TOTAL: & 3,874 & 0 & 3,562 & 279 & 3,841 & 541 & 0 & 0 & 0 & 0 & 3,749 & 262 & 3,506 & 0 & 3,768 & 0 & 243 & 0 & 312 & 555 & & & & \\
\hline
\end{tabular}

Total 8 Hour Vehicle Volume: 8,164

Total 8 Hour Bicycle Volume: 39

Total 8 Hour Intersection Volume: $\mathbf{8 , 2 0 3}$ 


\section{[II TORONTO}

City of Toronto - Traffic Safety Unit

Turning Movement Count Summary Report

DORIS AVE AT HOLLYWOOD AVE

Survey Date:

2013-May-13

(Monday)

Survey Type: Routine Hours

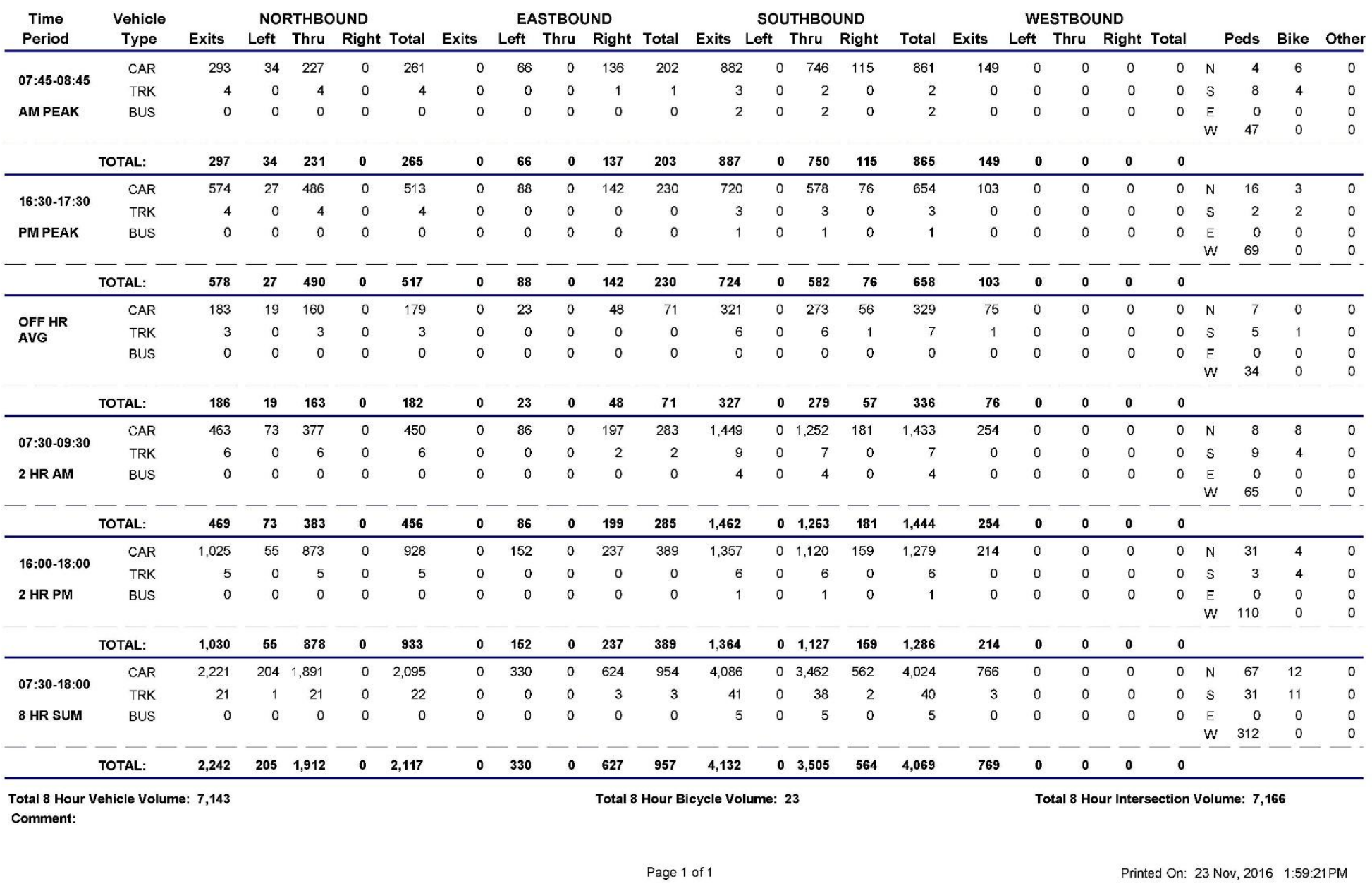




\section{APPENDIX B: MODEL CRITERIA AND \\ CALCULATION PROCESS}

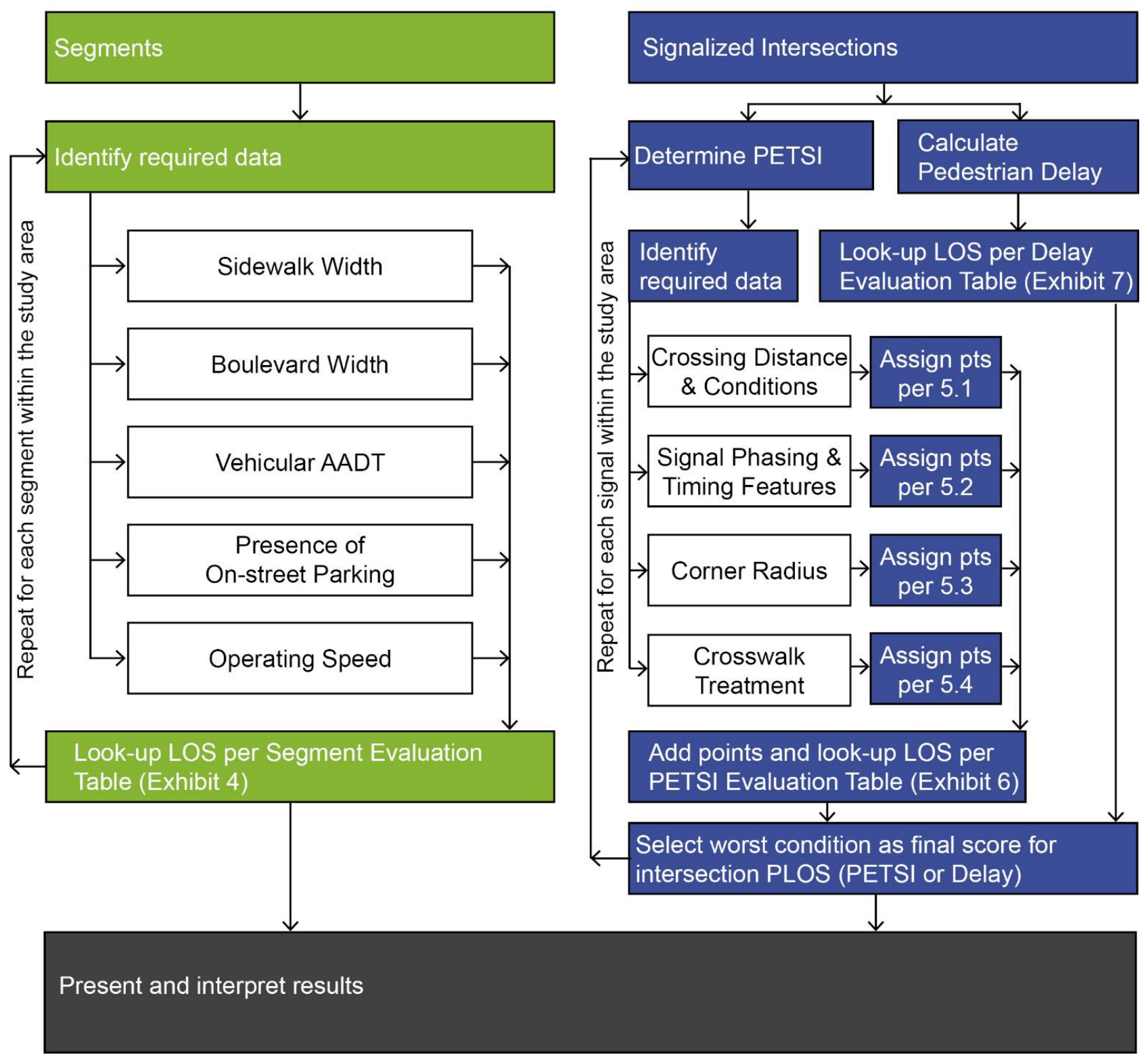

Figure B1: PLOS Evaluation Methodology 


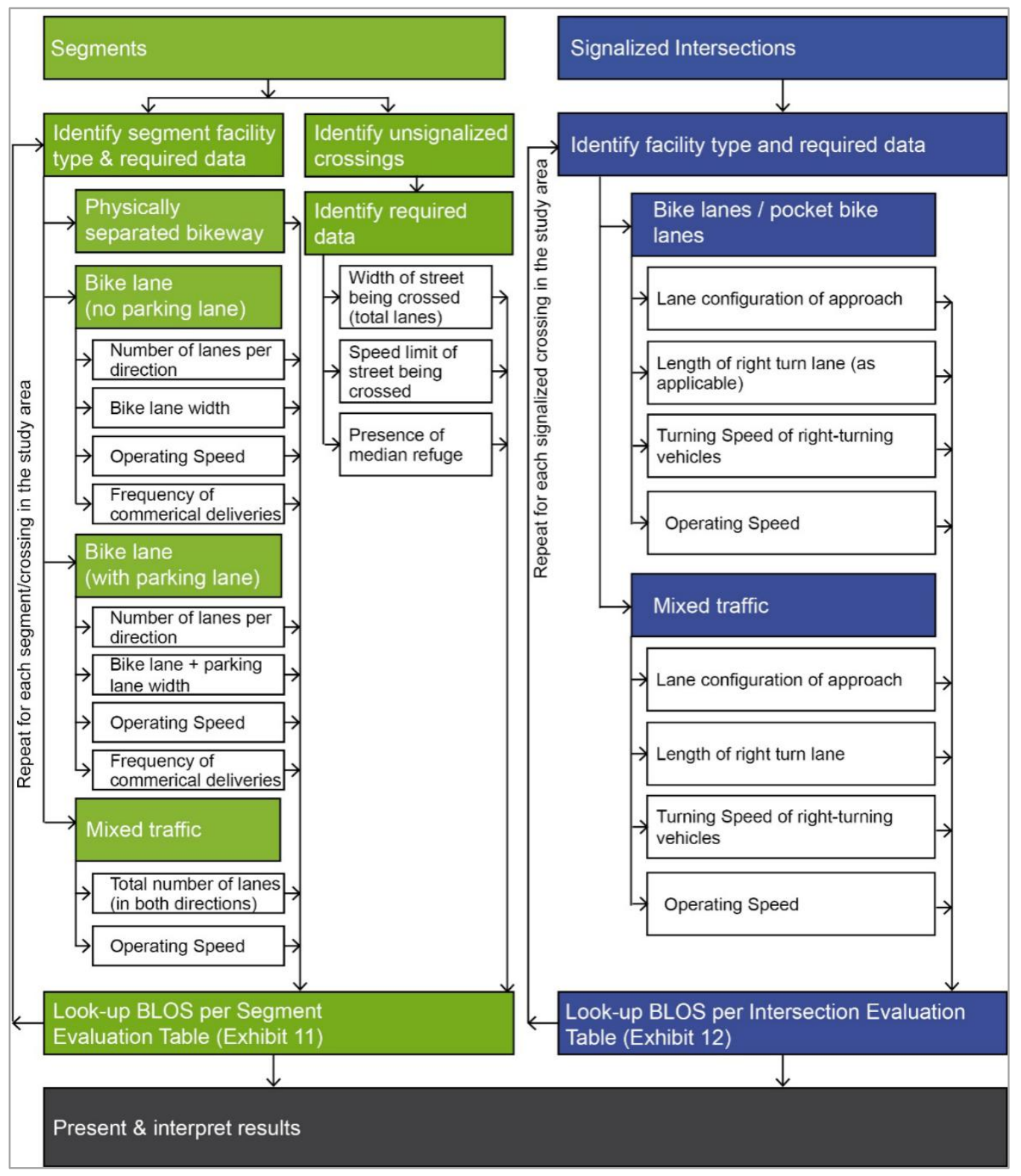

Figure B2: BLOS Evaluation Methodology 


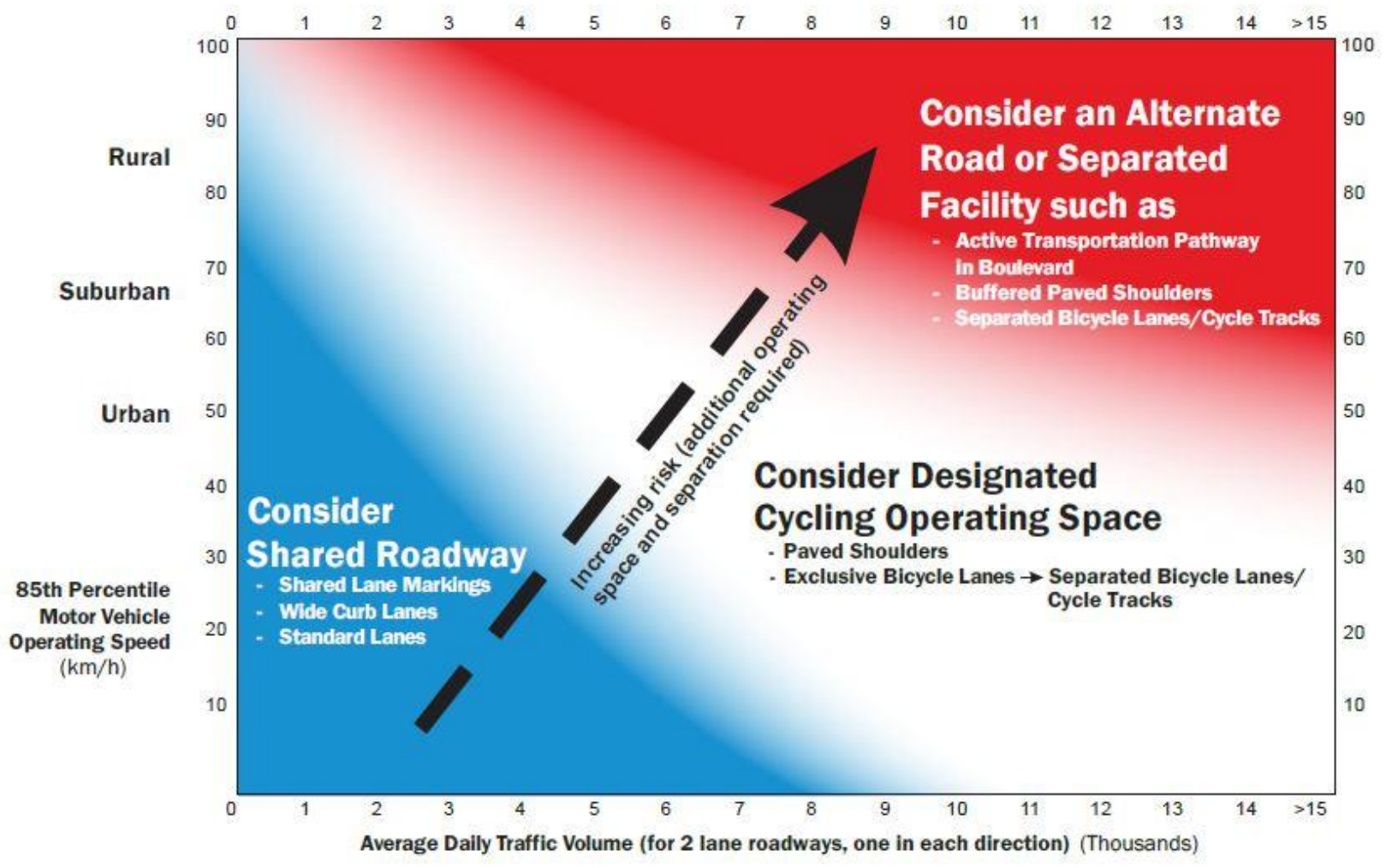

Figure B3: Cycling facilities Consideration criteria based on OTM guidelines 
Table B1: Connectivity Index Calculation

\begin{tabular}{|c|c|c|c|c|c|c|}
\hline $\mathbf{S} / \mathbf{N}$ & $\begin{array}{l}\text { Census } \\
\text { Tract } \\
\text { number }\end{array}$ & \# Link & \# Node & $\begin{array}{l}\text { Connectivity } \\
\text { Index }\end{array}$ & Category & $\begin{array}{l}\text { Desirable } \\
\text { Zone }\end{array}$ \\
\hline 1 & 5350297.01 & 8 & 5 & 1.60 & Fused-Grid Networks & Yes \\
\hline 2 & 5350299.01 & 67 & 39 & 1.72 & Fused-Grid Networks & Yes \\
\hline 3 & 5350299.02 & 13 & 10 & 1.30 & Complete Connectivity & Yes \\
\hline 4 & 5350306.01 & 86 & 75 & 1.15 & Curvilinear Networks & No \\
\hline 5 & 5350306.02 & 87 & 72 & 1.21 & Curvilinear Networks & No \\
\hline 6 & 5350307.03 & 21 & 14 & 1.50 & $\begin{array}{l}\text { Future Greenfield Residential } \\
\text { Communities }\end{array}$ & No \\
\hline 7 & 5350307.04 & 16 & 13 & 1.23 & Curvilinear Networks & No \\
\hline 8 & 5350307.05 & 18 & 16 & 1.13 & Curvilinear Networks & No \\
\hline 9 & 5350307.06 & 15 & 12 & 1.25 & Curvilinear Networks & No \\
\hline 10 & 5350307.07 & 110 & 85 & 1.29 & Curvilinear Networks & No \\
\hline 11 & 5350308.01 & 112 & 80 & 1.40 & Modified Grid Networks & No \\
\hline 12 & 5350308.02 & 90 & 65 & 1.38 & Curvilinear Networks & No \\
\hline 13 & 5350318.00 & 122 & 102 & 1.20 & Curvilinear Networks & No \\
\hline 14 & 5350319.00 & 94 & 65 & 1.45 & Modified Grid Networks & No \\
\hline 15 & 5350320.01 & 45 & 34 & 1.32 & Curvilinear Networks & No \\
\hline 16 & 5350320.02 & 30 & 22 & 1.36 & Curvilinear Networks & No \\
\hline 17 & 5350321.01 & 114 & 78 & 1.46 & Modified Grid Networks & No \\
\hline 18 & 5350321.02 & 65 & 43 & 1.51 & $\begin{array}{l}\text { Future Greenfield Residential } \\
\text { Communities }\end{array}$ & No \\
\hline 19 & 5350322.01 & 9 & 6 & 1.50 & $\begin{array}{l}\text { Future Greenfield Residential } \\
\text { Communities }\end{array}$ & No \\
\hline 20 & 5350322.02 & 70 & 49 & 1.43 & Modified Grid Networks & No \\
\hline
\end{tabular}




\section{REFERENCES}

City of Ottawa. (2015). MULTI-MOD AL LEVEL OF SERVICE (MMLOS) GUIDELINES.

Retrieved from

http://app05.ottawa.ca/sirepub/cache/2/ubg0igmv3ekyoqx0auxf3e1p/31504603272017012 401692.PDF

City of Toronto. (2013). City of Toronto Road Classification System. Retrieved from https://www1.toronto.ca/City $\% 20$ Of $\% 20$ Toronto/Transportation $\% 20$ Services/Road $\% 20 \mathrm{C}$ lassification\%20System/Files/pdf/2012/rc_document.pdf

City of Toronto. (2015). Vehicle Travel Lane Width Guidelines. Toronto, Canada: Transportation Services, City of Toronto.

City of Toronto. (2016). Ten Year Cycling Network Plan. Retrieved from http://www.toronto.ca/legdocs/mmis/2016/pw/bgrd/backgroundfile-92811.pdf

City of Toronto Open Data Portal. (2017, April 10). City of Toronto Open Data. Retrieved from http:/ / www1.toronto.ca/wps/portal/ contentonly?vgnextoid=1a66e03bb8d1e310VgnVCM1 0000071d60f89RCRD

Clifton, K. J., Muhs, C., Morrissey, S., Morrissey, T., Currans, K., \& Ritter, C. (2013). EXAMINING CONSUMER BEHAVIOR AND TRAVEL CHOICES. Portland: Portland State University and OREGON TRANSPORTATION RESEARCH AND EDUCATION CONSORTIUM.

Creatore, M. I., Richard H., G., Rahim, M., Fazli, G. S., Johns, A., Gozdyra, P., . . Booth, G. L. (2016). Association of NeighborhoodWalkability With Change in Overweight, Obesity, and Diabetes. JAMA. 315(20), 2211-2220. 
Data Management Group. (2011). Transportaion Tomorrow Survey. Toronto, Ontario, Canada: University of Toronto.

Easa, S. M. (1993). Urban Trip Distribution in Practice II: Quick Response and Special Topics. Journal of Transportation Engineering, Vol. 119, No. 6, 816-834.

Fitzpatrick, K., Carlson, P., Brewer, M. a., Wooldridge, M. d., \& Miaou, S.-p. (2003). Design Speed, Operating Speed, and Posted Speed Practices. WASHINGTON, D.C.: NCHRP REPORT 504, TRANSPORTATION RESEARCH BOARD.

Forsyth, A., \& Krizek, K. (2012). Promoting Walking and Bicycling: Assessing the Evidence to Assist Planners. BUILT ENVIRONMENT VOL 36 NO 4, 429-446.

Forsyth, A., Agrawal, A. W., \& Krizek, K. J. (2012). Simple, Inexpensive Approach to Sampling for Pedestrian and Bicycle Surveys: Approach Developed in Pedestrian and Bicycling Survey. Transportation Research Record: Journal of the Transportation Research Board, No. 2299, 22-30.

HCM. (2000). Highway Capacity Manual. Washington D.C.: Transportation Research Board.

HCM. (2010). Highway Capacity Manual. Washington D.C.: Transportation Research Board.

Karim, D. M. (2015). Narrower Lanes, Safer Streets. Canadian Institute of Transportation Engineers. Regina.

Kuzmyak, J. R., Walters, J., Bradley, M., \& Kockelman, K. M. (2014). Estimating Bicycling and Walking for Planning and Project Development: A Guidebook. WASHINGTON, D.C.: TRANSPORTATION RESEARCH BOARD.

League of Illinois Bicyclists. (2017, April 03). http:/ / rideillinois.org/. Retrieved from Bike/Ped Level of Service Calculators: http:// rideillinois.org/blos/losform.htm

Litman, T. (2011). Short and Sweet: Analysis of Shorter Trips Using National Personal Travel Survey Data. British Columbia: Victoria Transportation Policy Institute. 
Litman, T. (2017). Evaluating Active Transportation Benefits and Costs: Guide to V aluing Walking and Cycling Improvements and Encouragement Programs. British Columbia, Canada: Victoria Transport Policy Institute.

Litman, T., \& Eric, D. (2011). Transportation Cost and Benefit Analysis. British Columbia: Victoria Transport Policy Institute.

Mackett, R. L. (2003). Why do people use their cars for short trips? Transportation, 30: 329-349. Metrolinx and steer davis gleave. (2015). Regional Transportation Plan Review: Active Transportation Background Paper. Toronto, Canada: Metrolinx: An agency of the Government of Ontario.

Mitra, R. (2016). CYCLING BEHAVIOUR AND POTENTIAL IN THE GREATER TORONTO AND HAMILTON AREA. Toronto, Canada: TRANSFORM, Research Labratory at Ryerson University.

N. Rouphail, J. Hummer, J. Milazzo II, P. Allen. (1998). RECOMMENDED PROCEDURES FOR CHAPTER 13, "PEDESTRIANS," OF THE HIGHWAY CAP ACITY MANUAL. McLean, Virginia: Federal Highway Administration (FHWA): FHWA-RD-98-107. NACTO. (2011). Urban Bikeway Design Guide. Washignton: Island Press.

NACTO. (2013). Urban Street Design Guide. New York: Island Press.

New York City. (2006). Pedestrian Level of Service Study: Phase 1. City of New York: NYC Department of City Planning.

OTM. (2013). Ontario Traffic Manual - Book 18: Cycling Facilities. Ontario: Queen’s Printer.

Porter, C., Suhrbier, J., \& Schwartz, W. L. (1999). Forecasting Bicycle and Pedestrian Travel: State of the Practice and Research Needs . TRANSPORTATION RESEARCH RECORD, 1674(Paper No. 99-0750), 94-101. 
Saneinejad, S., Roorda, M. J., \& Kennedy, C. (2012). Modelling the Impact of Weather Conditions on Active Transportation Travel Behaviour. Transportation Research Part D: Transport and Environment, 17(2): 129-137.

Semler, C., Vest, A., Kingsley, K., Mah, S., Kittelson, W., Sundstrom, C., \& Brookshire, K. (2016). Guidebook for Developing Pedestrian and Bicycle Performance Measures. Washington, D.C.: U.S. Department of Transportation, Federal Highway Administration.

The City of Calgary. (2010). The Calgary Transportation Plan Connectivity Handbook. Retrieved from http://www.calgary.ca/Transportation/TP/Documents/CTP2009/ctp_connectivity_handb ook.pdf

Toronto Public Health. (2012). Road to Health: Improving Walking and Cycling in Toronto. Toronto, Ontario, Canada: City of Toronto, Public Health .

Transportation Association of Canada. (2017, April 20). Geometric Design Guide for Canadian Roads New Edition. Retrieved from http://www.tac-atc.ca/en/projects/production/geometricdesign-guide-canadian-roads-new-edition

Victoria Transport Policy Institute . (2010). Roadway Connectivity Creating More Connected Roadway and Pathway Networks. Victoria Transport Policy Institute- TDM Encyclopedia. 